\title{
Potent colchicine-site ligands with improved intrinsic solubility by replacement of the 3,4,5-trimethoxyphenyl ring with a 2-methylsulfanyl-6- methoxypyridine ring
}

\author{
Raquel Álvarez ${ }^{\mathrm{a}, \mathrm{c}, \mathrm{d}}$, Laura Aramburu ${ }^{\mathrm{a}, \mathrm{c}, \mathrm{d}}$, Consuelo Gajate ${ }^{\mathrm{b}}$, Alba Vicente-Blázquez ${ }^{\mathrm{a}, \mathrm{b}, \mathrm{c}, \mathrm{d}}$, \\ Faustino Mollinedo ${ }^{\mathrm{b}}$, Manuel Medarde ${ }^{\mathrm{a}, \mathrm{c}, \mathrm{d}}$, Rafael Peláez ${ }^{\mathrm{a}, \mathrm{c}, \mathrm{d}, *}$ \\ ${ }^{a}$ Laboratorio de Química Orgánica y Farmacéutica, Departamento de Ciencias Farmacéuticas, Universidad de Salamanca, Campus Miguel de Unamuno, E-37007 \\ Salamanca, Spain \\ ${ }^{\mathrm{b}}$ Laboratory of Cell Death and Cancer Therapy, Department of Molecular Biomedicine, Centro de Investigaciones Biológicas, Consejo Superior de Investigaciones Cientificas \\ (CSIC), E-28040 Madrid, Spain \\ ' Instituto de Investigación Biomédica de Salamanca (IBSAL), Facultad de Farmacia, Universidad de Salamanca, Campus Miguel de Unamuno, E-37007 Salamanca, Spain \\ ${ }^{\mathrm{d}}$ Centro de Investigación de Enfermedades Tropicales de la Universidad de Salamanca (CIETUS), Facultad de Farmacia, Universidad de Salamanca, Campus Miguel de \\ Unamuno, E-37007 Salamanca, Spain
}

A R T I C L E I N F O

\section{Keywords:}

Pyridine derivatives

Combretastatins, isocombretastatins and

phenstatins

Solubility

Antimitotic

Docking

\begin{abstract}
A B S T R A C T
Colchicine site antimitotic agents typically suffer from low aqueous solubilities and are formulated as phosphate prodrugs of phenolic groups. These hydroxyl groups are the aim of metabolic transformations leading to resistance. There is an urgent need for more intrinsically soluble analogues lacking these hydroxyl groups. The 3,4,5-trimethoxyphenyl ring of combretastatin A-4 is a liability in terms of solubility but it is considered essential for high cytotoxic and tubulin polymerization inhibitory (TPI) activity. We have synthesized 36 new analogues of combretastatin A-4 replacing the trimethoxyphenyl moiety with more polar pyridine based moieties, measured their aqueous solubility, and studied their anti-proliferative effects against 3 human cancer cell lines. We show here that pyridine rings can be successful replacements for the trimethoxyphenyl ring, resulting in potent and more soluble analogues. The more straightforward replacement, a 2,6-dimethoxypyridine ring led to inactive analogues, but a 2-methoxy-6-methylsulfanylpyridine moiety led to active analogues when combined with different B rings. This replacement led to potent cytotoxic activity against sensitive human cancer cell lines due to tubulin inhibition, as shown by cell cycle analysis, confocal microscopy, and tubulin polymerization inhibitory activity studies. Cell cycle analysis also showed apoptotic responses following treatment. Docking studies suggested binding at the colchicine site of tubulin and provided a good agreement with the observed SAR. A 2-methoxy-6-methylsulfanylpyridine moiety is a good trimethoxyphenyl ring replacement for the development of new colchicine site ligands.
\end{abstract}

\section{Introduction}

The microtubules are part of the cytoskeleton of the eukaryotic cells and are involved in the maintenance of the cell shape, in the intracellular trafficking of organelles and vesicles, in the functioning of cilia and flagella and in the cellular events occurring during the mitotic cell division [1]. These essential functions are dependent on the dynamic polymerization equilibria of microtubules consisting on assembly and disassembly from the microtubules of their main constituents, the $\alpha \beta$-tubulin heterodimers. Many anti-tumor and anti-parasitic drugs exert their actions by altering the dynamic behaviour of the microtubules (microtubule-targeting agents or MTAs), some promoting (microtubule stabilizing agents or MSAs) and some opposing (microtubule destabilizing agents or MDAs) polymerization depending on their preferential binding to tubulin or the microtubules [2]. MTAs usually bind specifically to one of the several known binding sites available in the tubulin heterodimers, such as the taxanes, the vinca alkaloids, or the colchicine sites, thus determining their effects. The binding of MDAs to

\footnotetext{
* Corresponding author at: Laboratorio de Química Orgánica y Farmacéutica, Departamento de Ciencias Farmacéuticas, Facultad de Farmacia, Campus Miguel de Unamuno, E-37007 Salamanca, Spain.

E-mail addresses: raquelalvarez@usal.es (R. Álvarez), lauramvil@usal.es (L. Aramburu), cgajate@cib.csic.es (C. Gajate), avicenteblazquez@usal.es (A. Vicente-Blázquez), fmollin@cib.csic.es (F. Mollinedo), medarde@usal.es (M. Medarde), pelaez@usal.es (R. Peláez).
} 


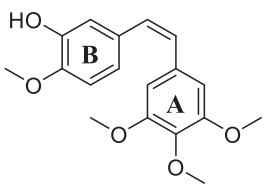

Combretastatin A-4

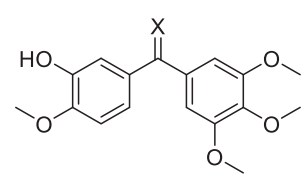

$\mathrm{X}=\mathrm{O}$ Phenstatin

$\mathrm{X}=\mathrm{CH}_{2}$ Isocombretastatin

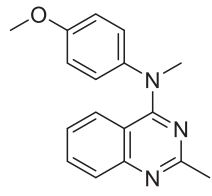

Verubulin

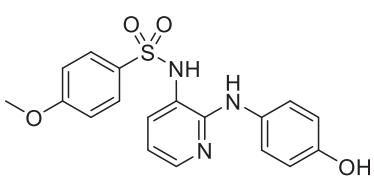

ABT-751

Fig. 1. Representative colchicine - site type ligands.

tubulin results in inhibition of the mitotic spindle (anti-mitotic effect), cell cycle arrest at the metaphase to anaphase transition with cells accumulating in the $\mathrm{G}_{2} / \mathrm{M}$ phase, and late apoptosis of cancer cells [3] and a rapid in vivo collapse of the vasculature (vascular disrupting agents or VDAs) which shuts down solid-tumours blood flow, thus causing tumor death $[4,5]$.

The colchicine site is located at the interface between the tubulin monomers and drug binding prevents the curved to straight transition of tubulin heterodimers, thus blocking tubulin polymerization (MDA). In recent years many colchicine site ligands (Fig. 1), both natural and synthetic, have been discovered and applied as VDAs, such as the phosphate prodrugs of combretastatin A-4 (CA4P, fosbretabulin) and combretastatin A-1 (CA1P, Oxi4503) and the amino analogue AVE8062, currently in clinical development [4-6] mainly in combination therapy together with cytotoxic drugs. Treatment with VDAs causes a rapid initial central tumour necrosis soon followed by regrowth of a peripheral rim of resistant viable cancer cells to the necrotic area causing recurrence and metastasis $[7,8]$. Cancer cells treated with combretastatin A-4 show innate and acquired resistance mechanisms, including adaptation to the hypoxic conditions and reestablishment of the vasculature in response to the reduction in blood supply as well as direct resistance to the drug. The main limitations of combretastatins are a low intrinsic aqueous solubility, the inactivation by isomerization of the $Z$ active isomer to the thermodynamically more stable $E$ isomer and the phase I and II metabolic transformations $[9,10]$. The low solubility has been mostly overcome by means of prodrugs incorporating solubilizing groups such as phosphates on the hydroxyl group of combretastatin A-4 [11] but this group is also involved in phase II metabolic transformations leading to resistance [12]. The isomerization problem has been tackled by formation of different cycles on the olefin which block the configuration $[13,14]$ or by means of configurationally invariable one-atom bridges, such as those of benzophenones (e.g. phenstatin) [11], 1,1-diarylethenes (e.g. isocombretastatin A-4) [15], and diarylamines (e.g. verubulin) [16].

The 3,4,5-trimethoxyphenyl ring of combretastatin A-4 (A ring) has long been considered as essential for high tubulin inhibitory and cytotoxic potency and is present in many derivatives despite its highly unfavourable pharmacokinetic properties due to its high volume and hydrophobicity [9]. It also suffers phase I metabolic reactions associated with inactivation by olefin isomerization, mainly after $O$-demethylation of the central methoxy group [10]. Recently, replacement of the lateral methoxy groups by halogen atoms (mainly iodine or bromine) has been shown to increase cytotoxic potency, but with no pharmacokinetic advantage [17]. Attempts to improve the pharmacokinetics of colchicine site ligands by increasing the polarity of the A ring, as for instance with pyridine rings as in ABT-751 leads to substantial potency reductions [18], and only recently a new family of pyridine-chalcones with high potency has been described [19].

Here we have explored the possibility of replacing the 3,4,5-trimethoxyphenyl ring (A ring) of combretastatin and isocombretastatin analogues with a pyridine moiety, with the added heterocyclic nitrogen replacing the attachment carbon of the central methoxy group. We anticipated that this substitution might preserve the polar interaction with the thiol group of Cys241ß of tubulin that is usually considered as a key interaction in colchicine analogues, while significantly improving the polarity and aqueous solubility of the resulting analogues. We have also successfully introduced methylsulfanyl groups in replacement of one of the lateral methoxy groups to partially compensate for the size reduction associated with the loss of the central methoxy group. In an attempt to explore the different SARs observed for colchicine site analogues with different bridge lengths we have combined the pyridine rings with 1,2-ethenylene (combretastatin), 1,1-ethenylidene (isocombretastatin), and carbonyl (phenstatin) bridges and with different $\mathrm{B}$ rings that have produced potent analogues when combined with the classical 3,4,5-trimethoxyphenyl ring, such as naphthalene [20,21], indoles with and without 3-substituents [21-23], 4-methoxy- [15], and 4-dimethylaminophenyl rings [24]. As expected, substantial overall solubility improvements were achieved, and highly potent tubulin polymerization inhibition was observed for several analogues, with even submicromolar $\mathrm{IC}_{50}$ values, better than those observed for combretastatin A-4. Cytotoxic potencies in the mid nanomolar range were also found for the most potent derivatives against sensitive HeLa human cervix epithelioid carcinoma and HL-60 human acute myeloid leukemia cell lines and submicromolar against the combretastatin A-4-resistant colon adenocarcinoma (HT-29) cell line. These effects were accompanied by accumulation of cells in the $\mathrm{G}_{2} / \mathrm{M}$ cell cycle phase after $24 \mathrm{~h}$ of drug treatments at concentrations of $100 \mathrm{nM}$ and significant sub- $\mathrm{G}_{0} /$ $\mathrm{G}_{1}$ cell fractions after $48 \mathrm{~h}$ treatment. The effects of the compounds on the cytoskeleton were confirmed by immunofluorescence studies. These results show that replacement of the A phenyl ring of combretastatin analogues by pyridine rings is a suitable strategy for achieving improved water solubility while maintaining high cytotoxic potency through tubulin polymerization inhibition.

\section{Results and discussion}

\subsection{Chemistry}

\subsubsection{Chemical synthesis}

We have employed the Wittig reaction between appropriate phosphonium ylides and aromatic aldehydes for the synthesis of the combretastatins, and nucleophilic additions of aryl-lithium derivatives to pyridine carboxylic acids, prepared from citrazinic acid as shown in Scheme 1, for the synthesis of diarylketones, as shown in Schemes 2-3 $[15,21]$. We synthesized 2,6-dichloroisonicotinic acid (1) from citrazinic acid by treatment with neat phosphorous oxychloride and tetramethylammonium chloride [25]. Nucleophilic aromatic substitutions of the chlorine atoms with sodium methoxide or sodium methanethiolate at room temperature gave the monosubstituted acids 2 and 3. Substitution of the second chlorine atom required heating, and 2,6dimethoxyisonicotinic acid (4) was prepared from either citrazinic acid or 2 with excess sodium methoxide in refluxing diglyme. 2-Methoxy-6(methylsulfanyl)isonicotinic acid (5) could not be prepared by heating acid $\mathbf{2}$ in the presence of sodium methanethiolate, but was obtained in good yield from 3 by treatment with excess sodium methoxide in refluxing diglyme. Acids $\mathbf{4}$ and $\mathbf{5}$ were used in the synthesis of the pyridophenones. For the Wittig reactions, the carboxylic acids were reduced with LAH. The benzylic alcohol 6 was oxidized to the aldehyde 8 and benzylic alcohol 7 was converted into the corresponding benzylic bromide 9 by treatment with hydrobromic acid in acetic acid. Bromide $\mathbf{9}$ was rapidly transformed into the phosphonium salt $\mathbf{1 0}$ by treatment with triphenylphosphine in toluene.

We synthesized the combretastatins A (1,2-diarylethenes) by means of Wittig reactions between the phosphonium ylides formed by 


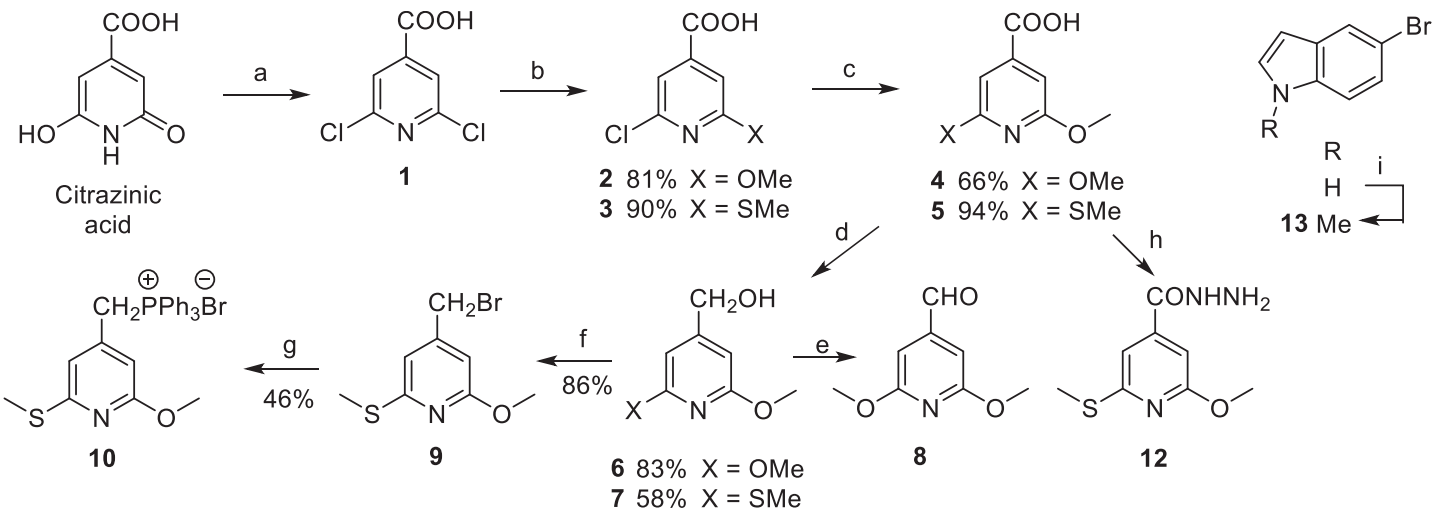

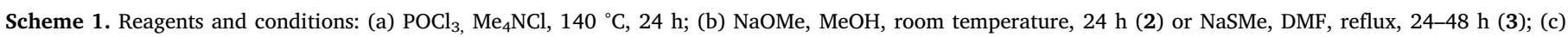

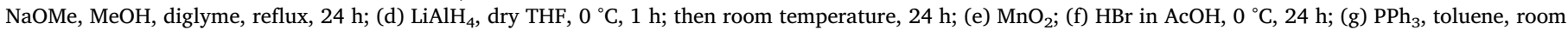

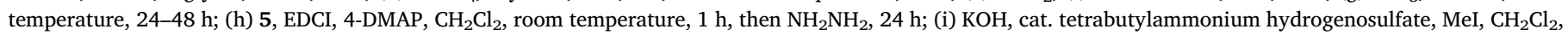
room temperature, $24 \mathrm{~h}$.

treatment of the phosphonium salts with $n$ BuLi and $N$-methylindole-5carbaldehyde (11), 3,4,5-trimethoxybenzaldehyde, 4-dimethylaminobenzaldehyde or $p$-anisaldehyde (Scheme 2). The $E$ and $Z$ isomers were chromatographically separated. Hydrogenation of the double bonds with Pd(C) yielded the combretastatins B. 2,3-Dihydrooxadiazoles were obtained by treatment of hydrazide 12 with $N$-methylindole-5-carbaldehyde, 4-dimethylaminobenzaldehyde or $p$-anisaldehyde in acetic anhydride.

The phenstatin and isocombretastatin analogues 24-44 were prepared as indicated in Scheme 3. We synthesized diaryl ketones 24-29 by means of nucleophilic additions of aryl-lithium reagents (prepared from the aryl bromides by treatment with $\mathrm{nBuLi}$ ) to isonicotinic acids 2 and 3 . The ketones were transformed in the oximes 34-36 by treatment with hydroxylamine and in the 1,1-diarylethenes (isocombretastatins) 30-33 by Wittig reaction using methyltriphenylphosphonium iodide. Hydrogenation of isocombretastatin 31 yielded ethane derivative $\mathbf{3 7}$. Nitration of $\mathbf{2 7}$ followed by reduction gave amine $\mathbf{3 9}$. Formyl indoles 40 and $\mathbf{4 3}$ were prepared by Vilsmeier - Haack formylation. 40 was converted into cyanoindoles $\mathbf{4 1}$ and $\mathbf{4 2}$ via the oximes by an acetylation - elimination sequence. Acid derivative 44 was prepared from 43 by electrophilic substitution with phosgene followed by hydrolysis. Oxidation of the methylsulfanyl groups of $\mathbf{2 6}$ and $\mathbf{2 8}$ with mCPBA allowed us to obtain the corresponding sulfoxides (45 and 47 ) and sulfones (46 and 48).
The synthesized compounds sample different combinations of $\mathrm{B}$ rings and bridges that have previously been shown to provide potent colchicine site ligands, and thus allow for a significant exploration of the potential of the pyridine analogues as cytotoxic and tubulin polymerization inhibitory agents, and were subsequently used in the biological assays.

\subsubsection{Aqueous solubility}

The low aqueous solubility is one of the main problems encountered in the development to the clinic of colchicine site ligands. The replacement of phenyl rings by pyridines should result in a significantly improved water solubility due to the increased polarity. Additional structural modifications, such as the introduction of amino groups as in 39 , the introduction of polar groups at the indole 3 position or the oxidation of thioethers to sulfoxides or sulfones are also expected to improve it. We have measured the solubility of representative compounds in phosphate buffer at $\mathrm{pH} 7.0$ using a shake-flask method, microfiltration and quantification of the dissolved compound by UV absorbance. Most of the compounds show a significant (more than tenfold, see table 1) improvement with respect to combretastatin A-4 and ABT-751, representative drugs of a trimethoxyphenyl or a pyridine A ring in clinical trials, respectively. Most of the attempts to improve the solubility of colchicine site ligands have been directed at the B ring and involve prodrugs of the hydroxyl group at position 3, which in turn<smiles>COc1cc(C[Pb]Br)cc(SC)n1</smiles><smiles>COc1cc(C=O)cc(OC)n1</smiles>

$13 \mathrm{X}=\mathrm{OMe}, \mathrm{Ar}=3,4,5-\mathrm{TM}$ $14 \mathrm{X}=\mathrm{OMe}, \mathrm{Ar}=4-\mathrm{MeOPh}$ $15 \mathrm{X}=\mathrm{OMe}, \mathrm{Ar}=2-\mathrm{Naphth}$ $16 \mathrm{X}=\mathrm{SMe}, \mathrm{Ar}=4-\mathrm{MeOPh}$ $17 \mathrm{X}=\mathrm{SMe}, \mathrm{Ar}=1-\mathrm{Me}$ IND

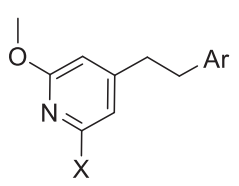

$18 \mathrm{X}=\mathrm{OMe}, \mathrm{Ar}=3,4,5-\mathrm{TM}$ $19 \mathrm{X}=\mathrm{OMe}, \mathrm{Ar}=4-\mathrm{MeOPh}$ $20 \mathrm{X}=\mathrm{OMe}, \mathrm{Ar}=2-\mathrm{Naphth}$
Scheme 2. Synthesis of pyridylcombretastatins and dihydrooxadiazole analogues. Reagents and conditions: (a) i) $n$ BuLi, dry THF, $-40^{\circ} \mathrm{C}, 1 \mathrm{~h}$; ii) $\mathrm{Ar}-\mathrm{CHO}$, $24 \mathrm{~h}$; (b) i) $\mathrm{Ar}-\mathrm{CH}_{2} \mathrm{PPh}_{3} \mathrm{Br}, n \mathrm{BuLi}$, dry THF, $-40{ }^{\circ} \mathrm{C}$, $1 \mathrm{~h}$; ii) 8, $24 \mathrm{~h}$; (c) $\mathrm{H}_{2}, \mathrm{Pd}(\mathrm{C})$, room temperature, 24-48 h; (d) i) EtOH $/ \mathrm{H}_{2} \mathrm{O} / \mathrm{AcOH}$ (25:5:0.2), aldehyde, $90{ }^{\circ} \mathrm{C}, 24 \mathrm{~h}$; ii) $\mathrm{Ac}_{2} \mathrm{O}, 160{ }^{\circ} \mathrm{C}, 1 \mathrm{~h}$. Abbreviations: 3,4,5-TM $=3,4,5$-trimethoxyphenyl; 4-MeOPh = 4-methoxyphenyl; 2-Naphth = 2Naphthyl; 1-MeIND = N-methyl-5-indolyl; 4$\mathrm{NMe}_{2} \mathrm{Ph}=$ 4-dimethylaminophenyl.<smiles>COc1cc(C(=O)NN)cc(SC)n1</smiles> 


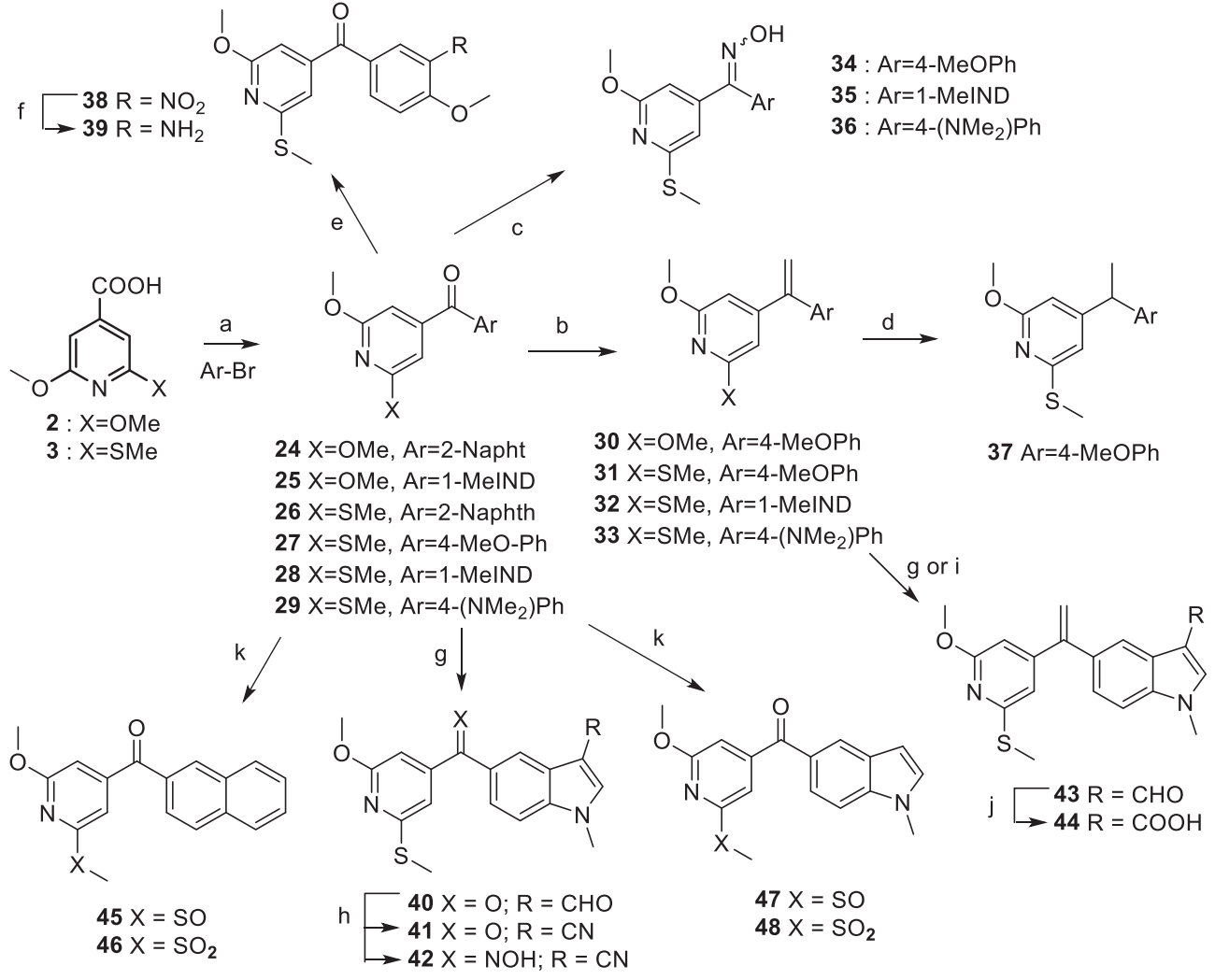

Scheme 3. Synthesis of pyridylphenstatins, pyridyloximes and pyridylisocombretastatin analogues. Reagents and conditions: (a) i) ArBr, $n B u L i$, dry THF, $-40^{\circ} \mathrm{C}, 1 \mathrm{~h}$, then 2 or 3; ii) room temperature, $24 \mathrm{~h}$; (b) i) $\mathrm{CH}_{3}$ $\mathrm{PPh}_{3} \mathrm{I}, n \mathrm{BuLi}$, dry THF, $-40{ }^{\circ} \mathrm{C}, 1 \mathrm{~h}$; ii) $27-$ 29, room temperature, $24 \mathrm{~h}$; (c) $\mathrm{NH}_{2} \mathrm{OH} \cdot \mathrm{HCl}, \mathrm{MeOH}$, pyridine, reflux, $24 \mathrm{~h}$; (d) $\mathrm{H}_{2}, \mathrm{Pd}(\mathrm{C})$, room temperature, 24-48 h; (e) $\mathrm{HNO}_{3}, \mathrm{H}_{2} \mathrm{SO}_{4}, \mathrm{CH}_{2} \mathrm{Cl}_{2}, 0{ }^{\circ} \mathrm{C}, 5 \mathrm{~min}$; (f) $\mathrm{Fe}, \mathrm{EtOH} / \mathrm{AcOH} / \mathrm{H}_{2} \mathrm{O}(2: 2: 1), 100{ }^{\circ} \mathrm{C}, 1 \mathrm{~h}$; (g) i) $\mathrm{POCl}_{3}$, dry $\mathrm{DMF}, 0{ }^{\circ} \mathrm{C}, 30 \mathrm{~min}$; ii) $\mathbf{2 8}$, heat to room temperature or $\mathbf{3 2}$ and heat to $60{ }^{\circ} \mathrm{C}, 2 \mathrm{~h}$; (h) i) $\mathrm{NH}_{2} \mathrm{OH} \cdot \mathrm{HCl}, \mathrm{MeOH}$, pyridine, reflux, $24 \mathrm{~h}$; ii) $\mathrm{Ac}_{2} \mathrm{O}$, pyridine, $130{ }^{\circ} \mathrm{C}, 24-48 \mathrm{~h}$; (i) Phosgene, $\mathrm{CH}_{2} \mathrm{Cl}_{2}$, room temperature, 24-48 h; j) oxidation; k) mCPBA, $\mathrm{CH}_{2} \mathrm{Cl}_{2}$, room temperature, 24-48 h. Abbreviations: 3,4,5-TM = 3,4,5trimethoxyphenyl; 4-MeOPh = 4-methoxyphenyl; 2-Naphth = 2-Naphthyl; 1MeIND $=N$-methyl-5-indolyl; 4$\mathrm{NMe}_{2} \mathrm{Ph}=$ 4-dimethylaminophenyl.
Table 1

Aqueous solubility of representative compounds in phosphate buffer at pH 7.0.

\begin{tabular}{|c|c|c|c|c|c|}
\hline \multirow[t]{2}{*}{ Comp } & \multirow[t]{2}{*}{ Bridge } & \multirow{2}{*}{ } & \multicolumn{2}{|l|}{$\mathrm{Ar}_{\mathrm{B}}$} & \multirow[t]{2}{*}{$\begin{array}{l}\text { Solubility } \\
(\mu \mathrm{g} / \mathrm{mL})\end{array}$} \\
\hline & & & $\mathrm{Ar}$ & $\mathrm{R}$ & \\
\hline CA-4 & Combretastatin & - & - & - & $1.04[26]$ \\
\hline 17 & Combretastatin & $\mathrm{SMe}$ & 1-MeIND & $\mathrm{H}$ & 19.1 \\
\hline 22 & Oxadiazole & $\mathrm{SMe}$ & 4-MeO-Ph & $\mathrm{H}$ & 9.8 \\
\hline 23 & Oxadiazole & $\mathrm{SMe}$ & 1-MeIND & $\mathrm{H}$ & 12.8 \\
\hline 27 & Phenstatin & $\mathrm{SMe}$ & 4-MeO-Ph & $\mathrm{H}$ & 17.0 \\
\hline 31 & Isocombretastatin & $\mathrm{SMe}$ & 4-MeO-Ph & $\mathrm{H}$ & 10.9 \\
\hline 33 & Isocombretastatin & $\mathrm{SMe}$ & 4- $\left(\mathrm{NMe}_{2}\right) \mathrm{Ph}$ & $\mathrm{H}$ & 43.8 \\
\hline 35 & Oxime & $\mathrm{SMe}$ & 1-MeIND & $\mathrm{H}$ & $<1$ \\
\hline 36 & Oxime & $\mathrm{SMe}$ & 4- $\left(\mathrm{NMe}_{2}\right) \mathrm{Ph}$ & $\mathrm{H}$ & 4.6 \\
\hline 39 & Phenstatin & $\mathrm{SMe}$ & 4-MeO-Ph & $3-\mathrm{NH}_{2}$ & 37.3 \\
\hline 40 & Phenstatin & $\mathrm{SMe}$ & 1-MeIND & 3-CHO & 15.5 \\
\hline 41 & Phenstatin & $\mathrm{SMe}$ & 1-MeIND & $3-\mathrm{CN}$ & 14.9 \\
\hline 44 & Isocombretastatin & $\mathrm{SMe}$ & 1-MeIND & $3-\mathrm{COOH}$ & 151.9 \\
\hline 45 & Phenstatin & SOMe & 2-Naphth & $\mathrm{H}$ & 34.5 \\
\hline
\end{tabular}

constitutes a means for drug resistance. The substitution of a trimethoxyphenyl ring by a 2-methylsulfanyl-6-methoxypyridine results in a ten-fold solubility increase in the combretastatins (compare $\mathbf{1 7}$ with indolecombretastatin, with a solubility of $2.6 \mu \mathrm{g} / \mathrm{mL}$ ) [22], but a more modest increase is observed for the isocombretastatins (compare 33 with its trimethoxyphenyl analogue, with a solubility of $30 \mu \mathrm{g} / \mathrm{mL}$ ) [23]. The phenstatins show similar solubilities of circa $15 \mu \mathrm{g} / \mathrm{mL}$, irrespective of the ring B (e.g. 27, 40 or 41) unless an additional solubilizing group such as an amino (39) or sulfoxide (45) group is present. Surprisingly, the oximes (e.g. 35 and 36 ) are much less soluble than the corresponding isocombretastatins (e.g. 31 and 33), whose solubilities are more dependent on the nature of the second aromatic ring.

\subsection{Biology}

\subsubsection{Cell viability}

We have assayed the effect of the synthesized compounds on cell viability by the XTT method against three types of human cancer cell lines (Table 2): HeLa human cervix epithelioid carcinoma, HL-60 human acute myeloid leukemia, and HT-29 human colon adenocarcinoma [27]. Combretastatins, phenstatins, oximes, and isocombretastatins carrying a 2,6-dimethoxypyridine ring, the most direct replacement of the 3,4,5-trimethoxyphenyl ring, are inactive, while analogues carrying a 2-methylsulfanyl-6-methoxypyridine are cytotoxic at submicromolar concentrations. These results indicate that the substitution of the trimethoxyphenyl ring by a pyridine moiety can be successful. The most potent compounds of the series inhibited cell proliferation in the indicated human cancer cell lines at very low drug concentrations, with $\mathrm{IC}_{50}$ values in the double-digit nanomolar range. These IC $_{50}$ values are 5-25 times higher than those shown by combretastatin A-4 ( $\mathrm{IC}_{50}$ at a range between $10^{-9}$ and $10^{-8} \mathrm{M}$ ), one of the most potent compounds representative of the trimethoxyphenyl ring family, but are lower than those of ABT-751, a representative of the pyridine family of colchicine site ligands. The three cell lines show similar responses to the compounds, but HT-29 is somewhat less sensitive to the more potent compounds in the series, a difference in sensitivity which has been previously observed for other colchicine site ligands $[12,23]$.

Except for the oxadiazolines (21-23), which are all inactive, the different bridges connecting the two aromatic rings show small differences in cytotoxicity, with the oximes closely followed by the isocombretastatins and combretastatins, and the ketones showing lower potencies (e.g. compare 34, 31, 27 and 16 for the 4-methoxyphenyl series and 35, 32, 17 and $\mathbf{2 8}$ for the $N$-methylindole series), with the remarkable exception of ketone 39 , the most potent representative of the series. However, the nature of the bridge affects the relative potency of different $\mathrm{B}$ rings, thus suggesting different ring preferences for 
Table 2

Cytotoxic activity against human cancer cell lines and Tubulin Polymerization Inhibitory Activity (TPI).

\begin{tabular}{|c|c|c|c|c|c|c|c|c|}
\hline Comp & $\mathrm{X}$ & $\mathrm{Z}$ & $\mathrm{Ar}$ & $\mathrm{R}$ & $\mathrm{IC}_{50}$ Hela $(\mu \mathrm{M})^{\mathrm{a}}$ & $\mathrm{IC}_{50} \mathrm{HL}-60(\mu \mathrm{M})^{\mathrm{a}}$ & $\mathrm{IC}_{50}$ HT-29 $(\mu \mathrm{M})^{\mathrm{a}}$ & IC $_{50}$ TPI $(\mu \mathrm{M})^{t}$ \\
\hline 13 & $\mathrm{OMe}$ & Comb $(Z+E)$ & $3,4,5-\mathrm{TM}$ & $\mathrm{H}$ & $\geq 1$ & $\geq 1$ & $\geq 1$ & $>20$ \\
\hline $13 E$ & $\mathrm{OMe}$ & Comb $(E)$ & $3,4,5-\mathrm{TM}$ & $\mathrm{H}$ & $\geq 1$ & $\geq 1$ & $\geq 1$ & $>20$ \\
\hline 14 & $\mathrm{OMe}$ & Comb $(Z+E)$ & 4-MeO-Ph & $\mathrm{H}$ & 1.00 & - & $\geq 1$ & $>20$ \\
\hline $14 E$ & $\mathrm{OMe}$ & Comb $(E)$ & 4-MeO-Ph & $\mathrm{H}$ & $\geq 1$ & $\geq 1$ & $\geq 1$ & $>20$ \\
\hline 15 & $\mathrm{OMe}$ & Comb $(Z+E)$ & 2-Naphth & $\mathrm{H}$ & 0.740 & - & $\geq 1$ & $>20$ \\
\hline $15 E$ & $\mathrm{OMe}$ & $\operatorname{Comb}(E)$ & 2-Naphth & $\mathrm{H}$ & $\geq 1$ & $\geq 1$ & $\geq 1$ & $>20$ \\
\hline 16 & $\mathrm{SMe}$ & Comb $(Z)$ & 4-MeO-Ph & $\mathrm{H}$ & $\geq 1$ & $\geq 1$ & $\geq 1$ & 4.1 \\
\hline 17 & $\mathrm{SMe}$ & Comb $(Z)$ & 1-MeIND & $\mathrm{H}$ & $0.3 \pm 0.09$ & $0.4 \pm 0.3$ & $0.4 \pm 0.02$ & 1.0 \\
\hline 21 & $\mathrm{SMe}$ & Oxadiazo & 4-( $\left(\mathrm{NMe}_{2}\right) \mathrm{Ph}$ & $\mathrm{H}$ & $\geq 1$ & $\geq 1$ & $\geq 1$ & $>5$ \\
\hline 22 & $\mathrm{SMe}$ & Oxadiazo & 4-MeO-Ph & $\mathrm{H}$ & $\geq 1$ & $\geq 1$ & $\geq 1$ & $>5$ \\
\hline 23 & $\mathrm{SMe}$ & Oxadiazo & 1-MeIND & $\mathrm{H}$ & $\geq 1$ & $\geq 1$ & $\geq 1$ & $>5$ \\
\hline 24 & $\mathrm{OMe}$ & $\mathrm{C}=\mathrm{O}$ & 2-Naphth & $\mathrm{H}$ & $\geq 1$ & $\geq 1$ & $\geq 1$ & $>5$ \\
\hline 25 & $\mathrm{OMe}$ & $\mathrm{C}=\mathrm{O}$ & 1-MeIND & $\mathrm{H}$ & 0.990 & - & $\geq 1$ & $>20$ \\
\hline 26 & SMe & $\mathrm{C}=\mathrm{O}$ & 2-Naphth & $\mathrm{H}$ & $0.7 \pm 0.08$ & $\geq 1$ & $\geq 1$ & $>5$ \\
\hline 27 & SMe & $\mathrm{C}=\mathrm{O}$ & 4-MeO-Ph & $\mathrm{H}$ & $\geq 1$ & $\geq 1$ & $\geq 1$ & $>5$ \\
\hline 28 & $\mathrm{SMe}$ & $\mathrm{C}=\mathrm{O}$ & 1-MeIND & $\mathrm{H}$ & $0.1 \pm 0.03$ & $0.6 \pm 0.04$ & $\geq 1$ & $>5$ \\
\hline 29 & $\mathrm{SMe}$ & $\mathrm{C}=\mathrm{O}$ & 4-( $\left.\mathrm{NMe}_{2}\right) \mathrm{Ph}$ & $\mathrm{H}$ & $0.6 \pm 0.2$ & $0.5 \pm 0.2$ & $\geq 1$ & $>5$ \\
\hline 30 & $\mathrm{OMe}$ & $\mathrm{C}=\mathrm{CH}_{2}$ & 4-MeO-Ph & $\mathrm{H}$ & $\geq 1$ & $\geq 1$ & $\geq 1$ & $>5$ \\
\hline 31 & $\mathrm{SMe}$ & $\mathrm{C}=\mathrm{CH}_{2}$ & 4-MeO-Ph & $\mathrm{H}$ & $0.5 \pm 0.1$ & $0.3 \pm 0.01$ & $\geq 1$ & 4.1 \\
\hline 32 & $\mathrm{SMe}$ & $\mathrm{C}=\mathrm{CH}_{2}$ & 1-MeIND & $\mathrm{H}$ & $0.6 \pm 0.1$ & $0.3 \pm 0.1$ & $0.7 \pm 0.1$ & $>5$ \\
\hline 33 & $\mathrm{SMe}$ & $\mathrm{C}=\mathrm{CH}_{2}$ & 4-( $\left.\mathrm{NMe}_{2}\right) \mathrm{Ph}$ & $\mathrm{H}$ & $0.5 \pm 0.2$ & $0.3 \pm 0.02$ & $\geq 1$ & $>5$ \\
\hline 34 & $\mathrm{SMe}$ & $\mathrm{C}=\mathrm{NOH}$ & 4-MeO-Ph & $\mathrm{H}$ & $0.2 \pm 0.05$ & $0.3 \pm 0.04$ & $0.2 \pm 0.005$ & 1.3 \\
\hline 35 & $\mathrm{SMe}$ & $\mathrm{C}=\mathrm{NOH}$ & 1-MeIND & $\mathrm{H}$ & $0.2 \pm 0.04$ & $0.2 \pm 0.03$ & $\geq 1$ & 1.6 \\
\hline 36 & $\mathrm{SMe}$ & $\mathrm{C}=\mathrm{NOH}$ & 4-( $\left(\mathrm{NMe}_{2}\right) \mathrm{Ph}$ & $\mathrm{H}$ & $0.6 \pm 0.2$ & $0.3 \pm 0.1$ & $\geq 1$ & $>5$ \\
\hline 37 & $\mathrm{SMe}$ & $\mathrm{CH}-\mathrm{CH}_{3}$ & 4-MeO-Ph & $\mathrm{H}$ & $\geq 1$ & $\geq 1$ & $\geq 1$ & $>5$ \\
\hline 38 & $\mathrm{SMe}$ & $\mathrm{C}=\mathrm{O}$ & 4-MeO-Ph & $3-\mathrm{NO}_{2}$ & $\geq 1$ & $\geq 1$ & $\geq 1$ & $>5$ \\
\hline 39 & SMe & $\mathrm{C}=\mathrm{O}$ & 4-MeO-Ph & $3-\mathrm{NH}_{2}$ & $0.07 \pm 0.013$ & $0.06 \pm 0.02$ & $0.5 \pm 0.01$ & 0.9 \\
\hline 40 & $\mathrm{SMe}$ & $\mathrm{C}=\mathrm{O}$ & 1-MeIND & 3-CHO & $\geq 1$ & $\geq 1$ & $\geq 1$ & $>5$ \\
\hline 41 & SMe & $\mathrm{C}=\mathrm{O}$ & 1-MeIND & $3-\mathrm{CN}$ & $0.8 \pm 0.005$ & $0.2 \pm 0.02$ & $\geq 1$ & 2.9 \\
\hline 42 & $\mathrm{SMe}$ & $\mathrm{C}=\mathrm{NOH}$ & 1-MeIND & $3-\mathrm{CN}$ & $\geq 1$ & $\geq 1$ & $\geq 1$ & $>5$ \\
\hline 43 & $\mathrm{SMe}$ & $\mathrm{C}=\mathrm{CH}_{2}$ & 1-MeIND & 3-CHO & $0.4 \pm 0.01$ & $0.1 \pm 0.005$ & $0.7 \pm 0.07$ & 2.9 \\
\hline 44 & $\mathrm{SMe}$ & $\mathrm{C}=\mathrm{CH}_{2}$ & 1-MeIND & $3-\mathrm{COOH}$ & $\geq 1$ & $\geq 1$ & $\geq 1$ & $>5$ \\
\hline 45 & SOMe & $\mathrm{C}=\mathrm{O}$ & 2-Naphth & $\mathrm{H}$ & $\geq 1$ & $\geq 1$ & $\geq 1$ & $>5$ \\
\hline 46 & $\mathrm{SO}_{2} \mathrm{Me}$ & $\mathrm{C}=\mathrm{O}$ & 2-Naphth & $\mathrm{H}$ & $\geq 1$ & $\geq 1$ & $\geq 1$ & $>5$ \\
\hline 47 & SOMe & $\mathrm{C}=\mathrm{O}$ & 1-MeIND & $\mathrm{H}$ & $\geq 1$ & $\geq 1$ & $\geq 1$ & $>5$ \\
\hline 48 & $\mathrm{SO}_{2} \mathrm{Me}$ & $\mathrm{C}=\mathrm{O}$ & 1-MeIND & $\mathrm{H}$ & $\geq 1$ & $\geq 1$ & $\geq 1$ & $>5$ \\
\hline CA4 & - & - & - & - & 0.003 & 0.013 & 0.032 & $1-3$ \\
\hline ABT-751 & - & - & - & - & 0.388 & - & 0.514 & \\
\hline
\end{tabular}

a Values are derived from concentration-response curves using the XTT assay as described in the Experimental Section. Data are shown as the mean values of three experiments performed in triplicate.

b Tubulin polymerization inhibitory (TPI) IC $_{50}$.

bridges leading to different geometries. In isocombretastatins (1,1diarylethenes) and oximes, there are small differences in potency between 4-methoxyphenyl, $N$-methyl-5-indolyl and 4-dimethylaminophenyl (i.e. compare 31-33 and 34-36), whereas the $N$-methyl-5-indolyl is preferred over the 4-methoxyphenyl in combretastatins $(1,2-$ diarylethenes) and phenstatins (benzophenones) (i.e. compare 16-17 and 27-28).

Oxidation of the methylsulfanyl group to the corresponding sulfones and sulfoxides leads to a complete potency loss (i.e. compare 45 and 46 with 24 and 47 and 48 with 28). Substitutions at the indole 3 position are neutral or detrimental for the activity and dependent on the nature of the brigde: a carbaldehyde is preferred over a hydrogen in isocombretastatins (i.e. compare 32 and 43) whereas in ketones a formyl group is detrimental and a cyano group is preferred (i.e. compare $\mathbf{2 8}$, 40 and 41 ), which is in turn detrimental in the oximes (i.e. compare 36 and 42). In the 4-methoxyphenyl series, substitution at the three position with a nitro group is detrimental but an amino group causes a potency increase of more than ten-fold down to double-digit nanomolar (i.e. compare 39 with 27).

\subsubsection{Tubulin polymerization inhibition}

We have applied a turbidimetric method to measure the effect of the compounds at concentrations between 5 and $20 \mu \mathrm{M}$ on the total polymer mass formed from bovine brain tubulin under in vitro assembly conditions (Table 2). For those compounds inhibiting tubulin polymerization more than $50 \%$ at $5 \mu \mathrm{M}$, we have determined the $\mathrm{IC}_{50}$ values of microtubular protein polymerization inhibition (TPI). These values allowed us to compare the effects of the different compounds on the polymerization of tubulin and to the reference compounds combretastatin A-4 (one of the more potent tubulin polymerization inhibitors known with reported values between 1 and $3 \mu \mathrm{M}$ ) and ABT-751 (a representative of pyridine ligands with a TPI IC ${ }_{50}$ of $2-4 \mu \mathrm{M}$ ), and to analyze the relationship between structure and TPI. The TPI results follow similar trends to the cytotoxicity results, thus suggesting an implication of tubulin polymerization inhibition in the action mechanism. The non - cytotoxic dimethoxypyridines and the oxadiazoles show TPIs higher than $5 \mu \mathrm{M}$. For the methylsulfanylpyridine derivatives, the only B rings leading to TPI $\mathrm{IC}_{50}$ s lower than $5 \mu \mathrm{M}$ are the 4methoxyphenyl and $N$-methyl-5-indolyl of the combretastatin (16 and 17), isocombretastatin ( 31 and 43), oxime (34 and 35), and ketone (39 and 41) series. For TPI, the oximes are the most potent ( $c a 1 \mu \mathrm{M})$, followed by combretastatins, with isocombretastatins and benzophenones showing progressively descending potencies. The most potent analogues show TPI values comparable to or better than the reference compounds. The 3 amino substituent of 39 causes a remarkable potency increase which parallels the observed effect on cytotoxicity (compare 


\section{Microtubule network}

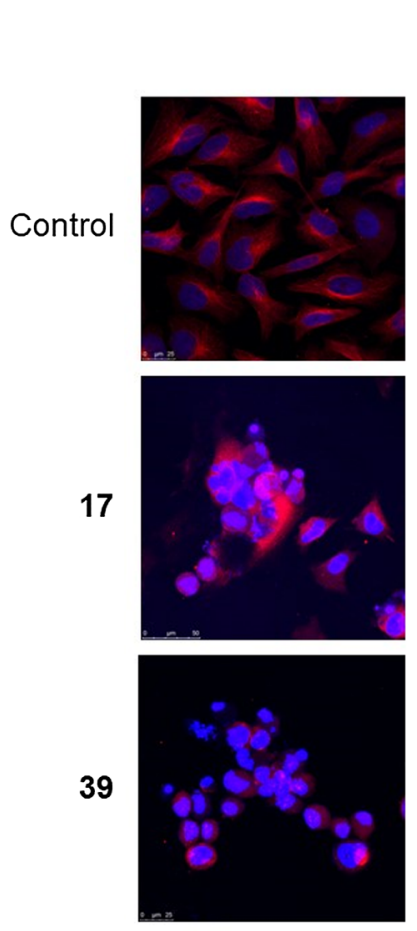

\section{Cell cycle}

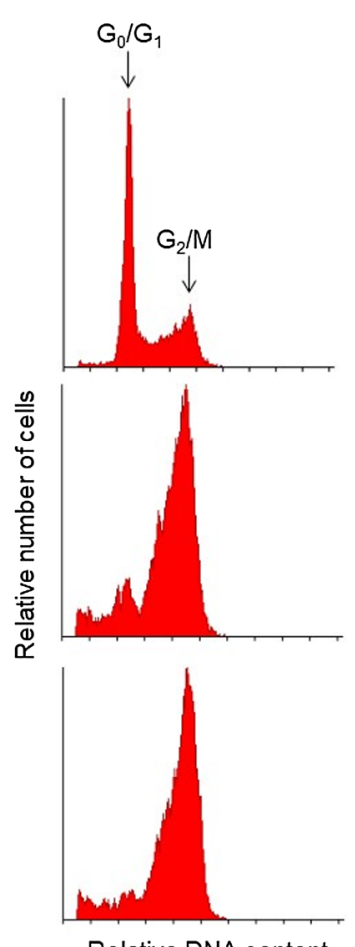

Relative DNA content

Fig. 2. Effects of compounds $\mathbf{1 7}$ and $\mathbf{3 9}$ on the microtubule network and cell cycle in HeLa cells. Cells were incubated in the absence (Control) or in the presence of $1 \mu \mathrm{M}$ of compounds $\mathbf{1 7}$ and $\mathbf{3 9}$ for $24 \mathrm{~h}$, and then fixed and processed to analyze microtubules (red fluorescence) and nuclei (blue fluorescence) by confocal microscopy as described in the Experimental Section. Bar: $25 \mu \mathrm{m}$ (control and 39) and $50 \mu \mathrm{m}$ (17). Cells were also analyzed in parallel by flow cytometry to determine their cell cycle profile. The photomicrographs and flow cytometry profiles shown are representative of three independent experiments. (For interpretation of the references to colour in this figure legend, the reader is referred to the web version of this article.)

39 with 27) and therefore seems to be at the root of it. Also, in the benzophenone series, the introduction of a 3-cyano substituent on the $\mathrm{N}$-methyl-5-indole results in a more moderate potency increase than for 39 but it is not accompanied by a similar increase in cytotoxic potency (compare 41 with 28).

The most potent inhibitors of tubulin polymerization are also the most potent cytotoxic compounds and the only ones active against the HT-29 cell line with the only exception of 32 , thus suggesting that interference with tubulin polymerization is at the origin of the observed cellular effects. The cytotoxic 4-dimethylaminophenyl (29, 33 and 36) and 2-naphthyl (26) analogues show TPI IC $_{50}$ values higher than $5 \mu \mathrm{M}$ with cytotoxicities comparable to more potent tubulin polymerization inhibitors such as 41 and 43. This difference could be explained by an effect associated more with polymerization dynamics than with changes of polymer mass, as previously proposed.

\subsubsection{Effects on cellular microtubules}

The two compounds that showed the lowest IC $_{50}$ for TPI, 17 $(1.0 \mu \mathrm{M})$ and $39(0.9 \mu \mathrm{M})$, promoted a drastic and severe disruption of the microtubule network in HeLa cells, as assessed by immunofluorescence confocal microscopy (Fig. 2). This microtubule disruption was accompanied by a cell cycle arrest at $G_{2} / M$ phase (Fig. 2). These results further confirm that the above observed effects were due to interaction of compounds $\mathbf{1 7}$ and $\mathbf{3 9}$ with tubulin.

\subsubsection{Effects on the cell cycle and induction of apoptosis}

A dose-response and time-course analysis of the above synthesized compounds, showed that the most potent compounds, 17 and 39 , in promoting microtubule disruption and inhibition of cell proliferation (Table 2), led to cell cycle arrest at $\mathrm{G}_{2} / \mathrm{M}$ followed by the induction of apoptosis, as assessed by the appearance of cells with sub- $\mathrm{G}_{0} / \mathrm{G}_{1}$ DNA content (Fig. 3).

Next, we carried out extensive dose-response and time-course analyses with the above microtubule-targeting compounds in different human cancer cells (Fig. 4). After $24 \mathrm{~h}$ incubation with HL-60, HeLa and HT-29 cells, compound $\mathbf{1 7}$ arrested most of the cells at the $\mathrm{G}_{2} / \mathrm{M}$ phase (78.5\%, $62.7 \%$ and $90.1 \%$ for HL-60, HeLa and HT-29, respectively) when used at only $100 \mathrm{nM}$ (Fig. 4). Under these experimental conditions (100 nM, $24 \mathrm{~h}$ incubation), compound 39 arrested $66.6 \%$ and $54.4 \%$ of HL-60 and HeLa cells at $\mathrm{G}_{2} / \mathrm{M}$ phase, respectively), whereas a higher concentration of $39(1 \mu \mathrm{M})$ was required to arrest HT-29 cells at $\mathrm{G}_{2} / \mathrm{M}$ phase $(89.7 \%)$ after $24 \mathrm{~h}$ incubation (Fig. 4). At this time point, HeLa cells already showed significant apoptosis induction, as evidenced by a substantial number of cells (22.9\% for 39 and $21.7 \%$ for 17 ) at the sub$\mathrm{G}_{0} / \mathrm{G}_{1}$ region. HL-60 and HT-29 showed a more delayed apoptotic response, which was evident at $48 \mathrm{~h}$ for compounds $\mathbf{1 7}(21.1 \%$ and $18.6 \%$ for HL-60 and HT-29 cells, respectively) and 39 (28.3\% and $16.8 \%$ for HL-60 and HT-29 cells, respectively) at the indicated concentrations (Fig. 4). After 48 h, HeLa cells showed an increase in the sub- $G_{0} / G_{1}$ population (from $22.9 \%$ after $24 \mathrm{~h}$ to $36.8 \%$ after $48 \mathrm{~h}$ for 39 , and from $21.7 \%$ after $24 \mathrm{~h}$ to $24.7 \%$ after $48 \mathrm{~h}$ for 17 ) accompanied by a reduction of the cells arrested at the $\mathrm{G}_{2} / \mathrm{M}$ phase (from $54.4 \%$ after $24 \mathrm{~h}$ to $28.7 \%$ after $48 \mathrm{~h}$ for 39 , and from $62.7 \%$ after $24 \mathrm{~h}$ to $50.5 \%$ after $48 \mathrm{~h}$ for 17 ) (Fig. 4). This trend continues for the three cell lines after $72 \mathrm{~h}$ (Fig. 4). These data suggest that the effects of $\mathbf{1 7}$ and $\mathbf{3 9}$ on microtubules disrupt microtubule polymerization, inducing a potent mitotic arrest that eventually triggers an apoptotic response, thus rendering a substantial cell demise in the drug-treated population.

\subsection{Computational studies}

The different effect of the methoxy and methylsulfanyl substituents at pyridine 6 position for matched molecular pairs of the synthesized compounds (e.g. on the TPI and cytotoxic potency) was investigated by means of DFT calculations in order to ascertain if they could be explained by their topological and/or electronic differences. The preferred conformation of the methoxy groups of the trimethoxyphenyl ring (Fig. 5) places the central methoxy group out of the plane of the phenyl ring due to steric hindrance with the ortho methoxy groups, which place their methyl carbons along the phenyl ring plane opposite to the central oxygen, due to steric hindrance as well. A second preferred conformation, $1.8 \mathrm{kcal} / \mathrm{mol}$ less stable, places the two lateral methoxy groups out of the ring plane with the central methoxy group protruding out of the plane of the phenyl ring on the opposite side. In the preferred conformation, the trimethoxyphenyl ring has its larger dimension along the ring plane in the 3-5 direction (methoxy carbon to methoxy carbon distance of 7.2 $\AA$ ). For the 2,6-dimethoxypyridines, the removal of the central methoxy group relieves the steric hindrance to the other methoxy groups, which orient themselves with their methyl groups towards the pyridine nitrogen. This results in a taller but less wide moiety (methoxy carbon to methoxy carbon distance of $4.5 \AA$ ). Rotation of one of the methoxy groups to place its methyl group anti to the pyridine nitrogen is very unfavorable $(6.1 \mathrm{kcal} / \mathrm{mol})$ due to the repulsive interactions of the lone pairs on the neighboring nitrogen and oxygen atoms. Substitution of one of the methoxy groups by a methylsulfanyl group results in a significant reduction of the penalty associated with the rotation of the carbon - sulfur bond to place the methyl anti to the nitrogen $(1.4 \mathrm{kcal} / \mathrm{mol})$, as the larger size of the sulfur atom reduces the repulsion between its lone pairs and that of the pyridine nitrogen. Furthermore, the longer carbon - sulfur bond lengths result in an almost complete recovery of the width of the 
17

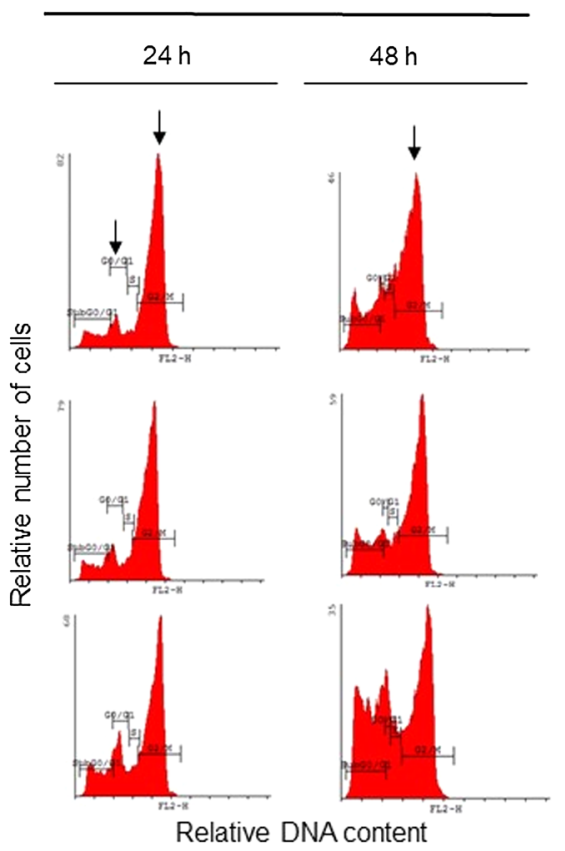

Control

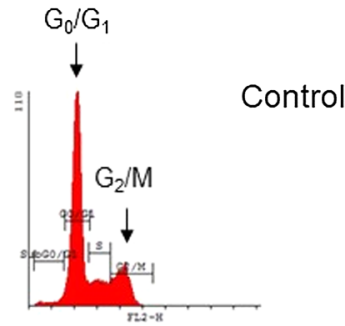

$100 \mathrm{nM}$

$1 \mu \mathrm{M}$

$48 \mathrm{~h}$
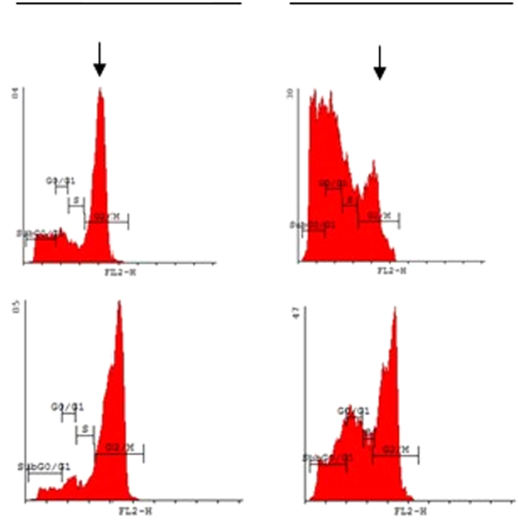

$10 \mu \mathrm{M}$
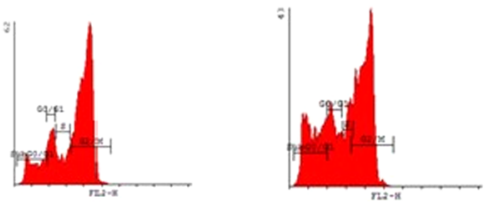

Relative DNA content

Fig. 3. Time-course and dose-response of the effects of compounds $\mathbf{1 7}$ and $\mathbf{3 9}$ on cell cycle in HeLa cells. Cells were incubated with different concentrations of $\mathbf{1 7}$ and

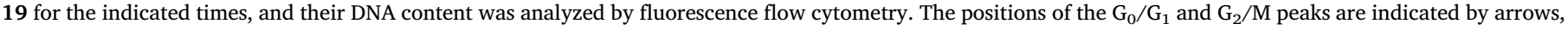
and the proportion of cells in each phase of the cell cycle was quantified by flow cytometry. The cell population in the sub- $G_{0} / G_{1}$ region represents cells with hypodiploid DNA content, an indicator of apoptosis. Untreated control cells were run in parallel. Data shown are representative of three independent experiments.

trimethoxyphenyl ring (methoxy carbon to methylsulfanyl carbon distance of $6.6 \AA$ ), thus explaining the recovery of the inhibitory activity. These results are in agreement with the observed disposition of the trimethoxyphenyl ring of different colchicine site analogues in complex with tubulin as determined by X-ray crystallographic studies (Fig. 5). Similar results are obtained for oxidations of the methylsulfanyl groups to the corresponding sulfoxide or sulfone (Fig. S1, Supplementary material), which preferentially place the oxygens of the sulfur atom anti to the pyridine nitrogen.

The binding mode of the synthesized compounds (Fig. 6) on tubulin has been investigated by docking experiments using 49 available X-ray crystal structures of tubulin in complex with different colchicine site ligands and 5 structures from molecular dynamics simulations, as previously described, in order to sample different protein configurations $[23,28]$. The proposed binding modes have been selected in a fully automated way as the optimal agreement of two docking programs with very different scoring functions (i.e. PLANTS [29] and AutoDock 4.2 $[30])$. For all the compounds assayed the preferred binding poses occupy the A (corresponding to the trimethoxyphenyl ring of combretastatin A-4) and B (corresponding to the 3-hydroxy-4-methoxyphenyl ring of combretastatin A-4) zones of the colchicine site [28,31]. The substituted pyridine rings occupy the A zone for all the compounds, except for compound 13, which places the trimethoxyphenyl ring in this zone while the pyridine sits in zone B. The methoxy and methylsulfanyl substituents on the pyridine ring are placed at either side of the A site depending on the remainder of the structure, thus suggesting that its binding mode is more determined by the geometrical constraints of the whole molecule rather than by an intrinsic preference of the substituents, in a similar way as observed for the SAR for the cytotoxic and TPI activities. The pyridine (A) ring is located in a hydrophobic pocket formed between helices $\mathrm{H7}$ and H8, sheets S8 and S9 and the T7 loop, contacting with the sidechains of Ala316 $\beta$, Val318 $\beta$, Leu248 $\beta$, Ala354 $\beta$, and Leu255 $\beta$, with the pyridine nitrogen atom hydrogen bonding with the thiol group of Cys241 $\beta$. The B rings are placed behind helix 8 and above sheets S8 and S9, making hydrophobic contacts with Met259 $\beta$, Thr314 $\beta$, and Lys352 $\beta$, and electrostatic interactions with Asn258 $\beta$. The bridges open toward the $\alpha \beta$ interface. A comparison of the docking scores across the different proteins shows that the optimal results are obtained for the X-ray crystal structure of tubulin when in complex with combretastatin A-4 (pdb ID 5LYJ) [32] and with a heterocyclic pyrimidine (pdb ID 6BRY) [33]. A comparison of the structures of these two ligands with the investigated compounds shows that they are quite similar (Fig. 6), thus providing a binding site more adapted to the docked virtual molecules. The optimal scores for the selected binding modes at each of these two proteins agreed better with the cytotoxicity or TPI ranking of the compounds than the overall best scores across all the protein sites, thus suggesting a more accurate comparison of the scores in a single site (Table S1, Suppl. Mat.). In any case, the inactive compounds $\mathbf{4 5}$ - $\mathbf{4 8}$ with oxidized methylsulfanyl groups (sulfones and sulfoxides) were scored as false positives, probably due to an inaccurate scoring of the sulfone and sulfoxide groups. The most potent compounds in cytotoxicity and TPI assays (i.e. 17 and 39) were ranked afterwards, in good agreement with the experimental results. 
17

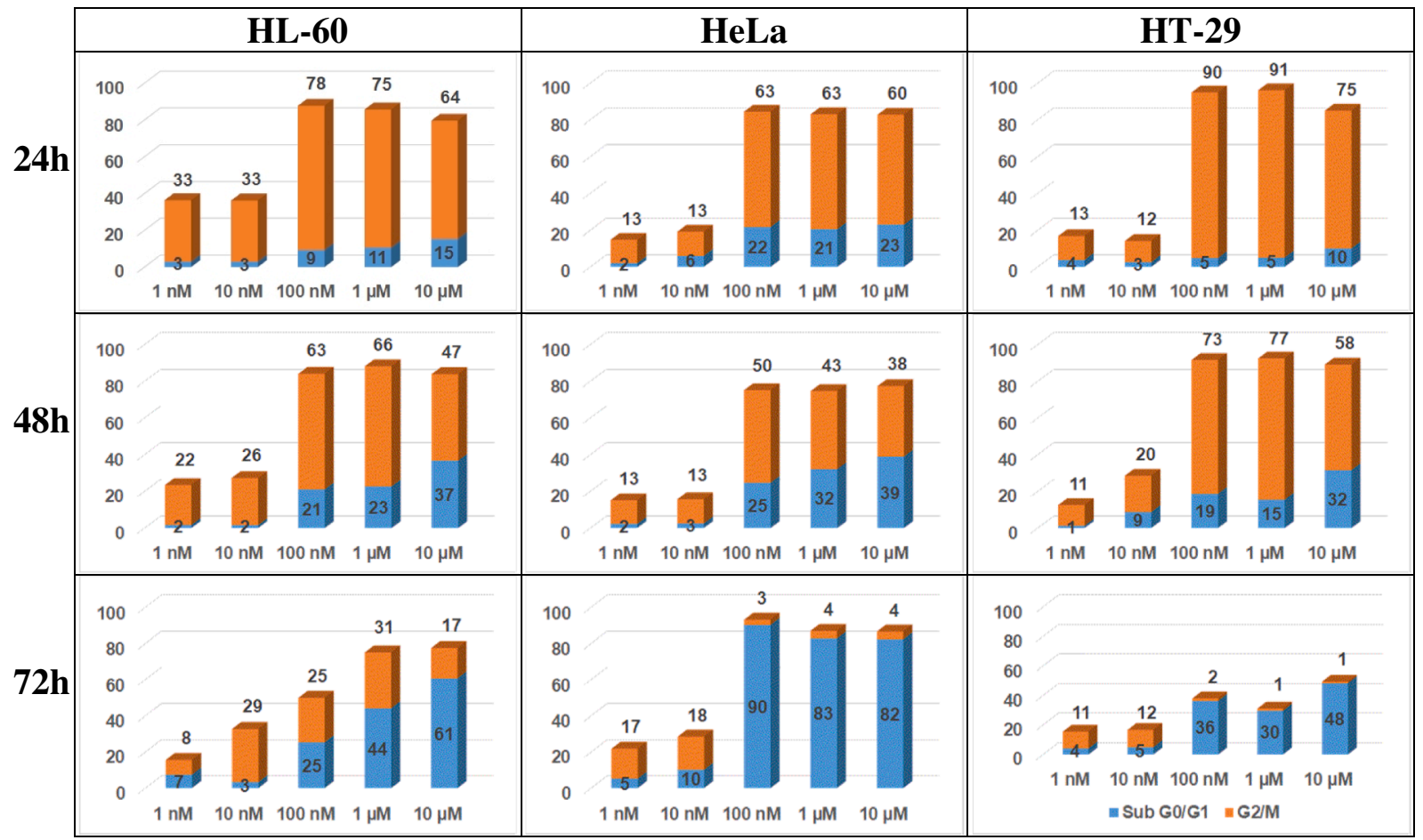

39

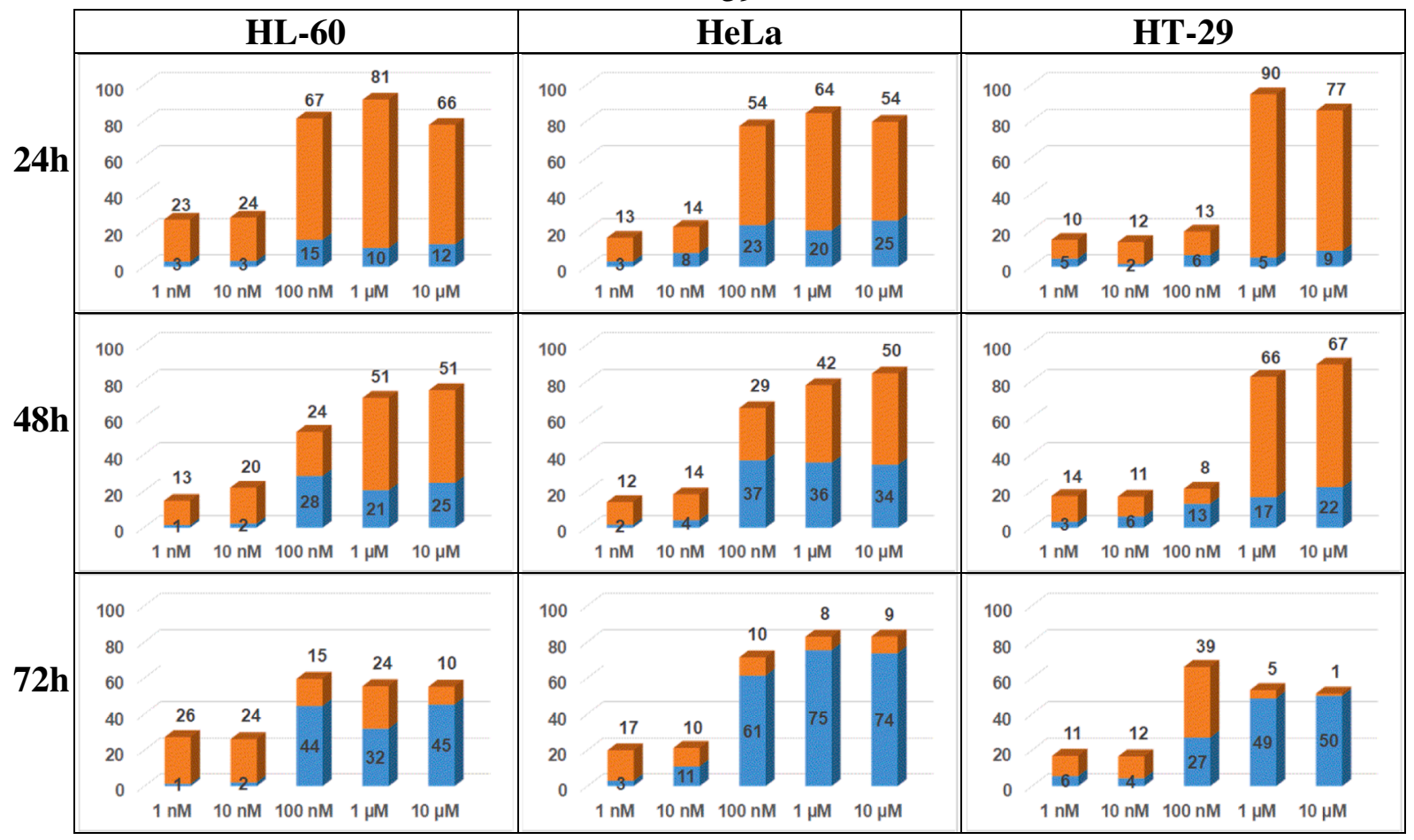

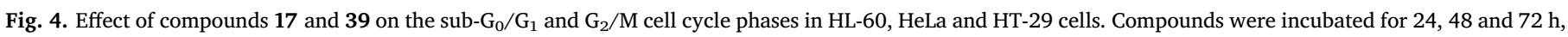

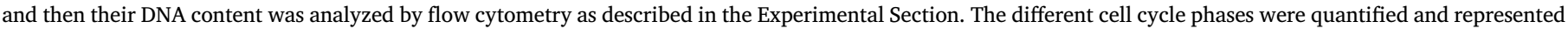

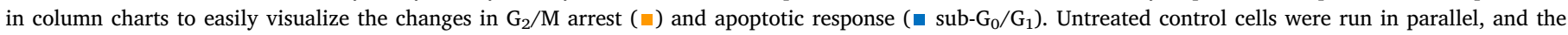

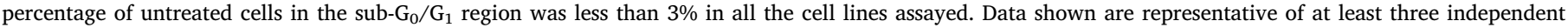
experiments.

\section{Conclusions}

The replacement of the 3,4,5-trimethoxyphenyl by a 2-methoxy-6methylsulfanyl-4-pyridyl moiety results in potent tubulin inhibition and cytotoxicity against several human cancer cell lines and significantly improves the intrinsic aqueous solubility of colchicine site ligands with bridges of 2 (combretastatins) or 1 (isocombretastatins, phenstatins and oximes) $\mathrm{sp}^{2}$ atoms. The effects of the other ring on potency vary with 
<smiles>CCN(CC)Cc1cc(OC)c(OC)c(OC)c1</smiles>

3,4,5-trimethoxyphenyl<smiles>[Y]C(C)C(C)C(C)C</smiles><smiles>CC(C)C(CC(C)(C)C)CC(C)(C)C</smiles>

$+1.75$
NON ACTIVE<smiles>COc1cc(C(C)(C)C)cc(OC)n1</smiles>

2,6-dimethoxy4-pyridinyl<smiles>COc1cc(C#N)cc(SC)n1</smiles>

2-methoxy-6(methylmercapto)-4-pyridinyl

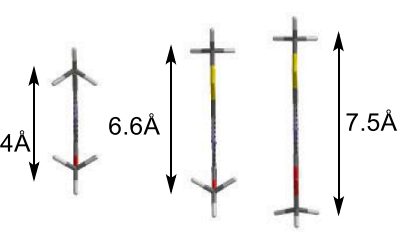

$+1.4+6.2$
Fig. 5. Structural comparison of the trimethoxyphenyl ring and the attempted substitutions: the 2,6-dimethoxy-4-pyridinyl and the 2-methoxy-6-methylsulfanyl-4-pyridinyl rings. The substituents are depicted in the $2 \mathrm{D}$ representation in the preferred dispositions. The different conformations are represented below in stick models looking at the rings from behind the central oxygen or the pyridine nitrogen along vertical axis and with a $90^{\circ}$ counterclockwise rotation of the ring planes as depicted above. The distances from methyl carbon to methyl carbon and the relative energies in $\mathrm{kcal} / \mathrm{mol}$ above the most stable (depicted in each case at the left most side) are indicated. the nature of the bridge between the two aromatic rings, with a 3amino-4-methoxyphenyl and a ketone bridge (39) providing the optimal combination of solubility and potency in the TPI and cytotoxicity assays. An indole ring also provides potent activity for the 1,2- diarylethene series. Substitutions on the indole ring or oxidation of the methylsulfanyl groups abolishes the cytotoxicity. The more potent compounds displayed cytotoxicity against several human cancer cell lines due to tubulin inhibition, with complete $\mathrm{G}_{2} / \mathrm{M}$ cell cycle arrest

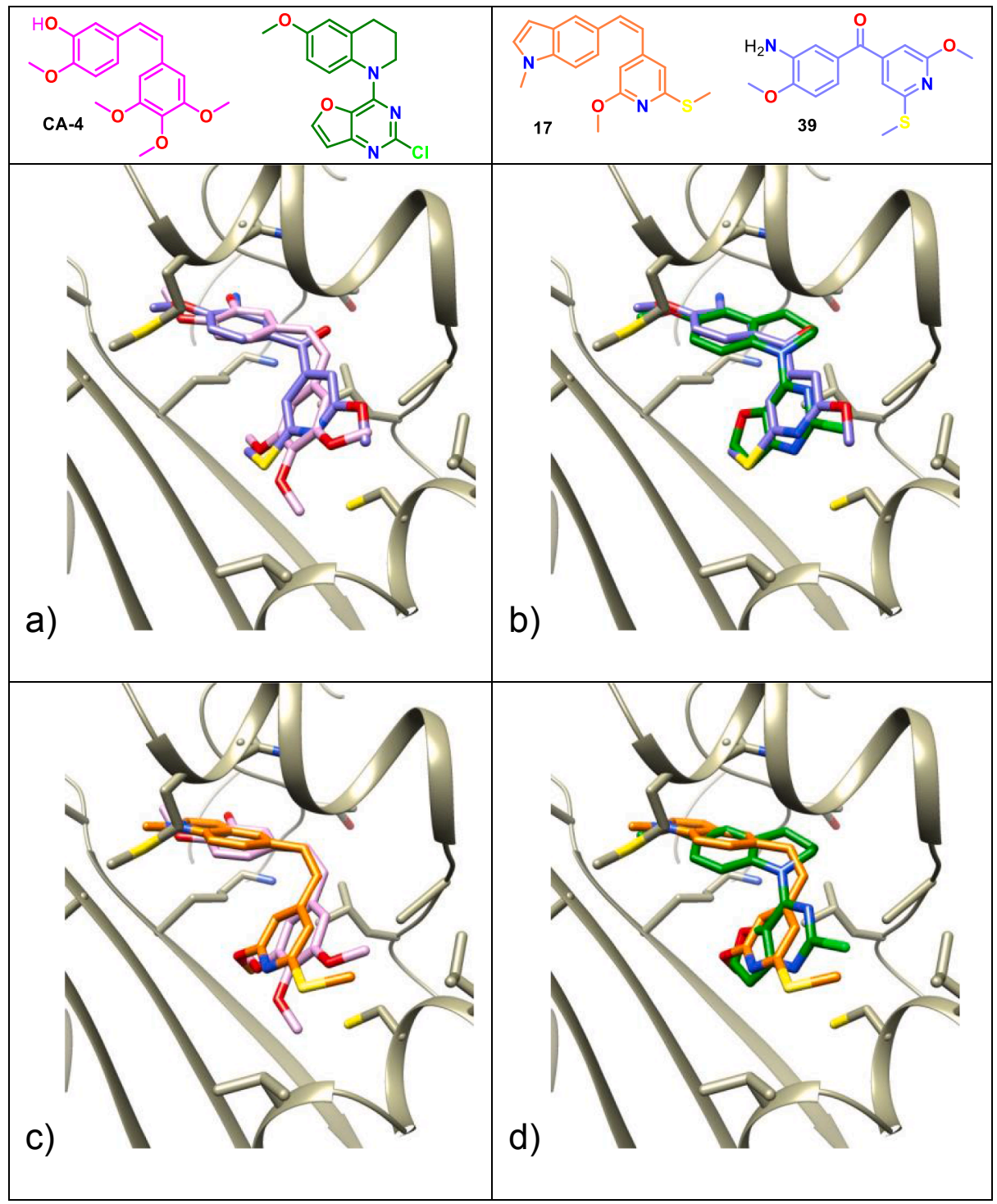

Fig. 6. Structures of the compounds depicted in a-d. Proposed binding modes for compounds $\mathbf{3 9}$ (a and b) depicted with carbons in violet and $\mathbf{1 7}$ (c and d) depicted with carbons in orange, superposed onto the X-ray structure of combretastatin A-4 (a and c, carbons in pink) and a heterocyclic pyrimidine (b and d, carbons in green) in their complexes with tubulin. The colchicine binding domain is depicted in gray (pdb ID 5LYJ). 
after $24 \mathrm{~h}$ followed by a high apoptosis-like cell response after 48-72 h. Molecular modelling studies support binding at the colchicine site and suggest binding of the pyridine moiety at the trimethoxyphenyl pocket of the colchicine site of tubulin and provide an explanation for the lack of activity of 2,6-dimethoxypyridine analogues and the potency increase observed for the 2-methoxy-6-methylsulfanylpyridine analogues. These compounds show improved aqueous solubility and therefore the structural modifications here described could be applied to improve colchicine site ligands.

\section{Experimental section}

\subsection{Chemistry}

\subsubsection{General chemical techniques}

Reagents were used as purchased without further purification. Solvents (THF, DMF, dichloromethane, and toluene) were dried and freshly distilled before use according to procedures described in the literature. TLC was performed on pre-coated silica gel polyester plates (0.25 mm thickness) with a UV fluorescence indicator 254 (Polychrom SI F254). Chromatographic separations were performed on silica gel columns by flash (Kieselgel 40, 0.040-0.063; Merck) or gravity (Kieselgel 60, 0.063-0.200 mm; Merck) chromatography. Melting points were determined on a Büchi 510 apparatus and are uncorrected. ${ }^{1} \mathrm{H}$ NMR and ${ }^{13} \mathrm{C}$ NMR spectra were recorded in $\mathrm{CDCl}_{3}$ on a Bruker WP 200-SY spectrometer at $200 / 50 \mathrm{MHz}$ or on a Bruker SY spectrometer at $400 / 100 \mathrm{MHz}$. Chemical shifts ( $\delta$ ) are given in ppm downfield from tetramethylsilane and coupling constants ( $J$ values) are in Hertz. IR spectra were run on a Nicolet Impact 410 Spectrophotometer. For FABHRMS analyses, a VG-TS250 apparatus $(70 \mathrm{eV})$ was used. HPLCs were

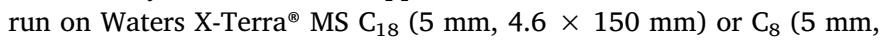
$4.6 \times 150 \mathrm{~mm}$ ) with acetonitrile/water solvent gradients. All the compounds described here were obtained with at least $95 \%$ of purity by quantitative HPLC and/or elemental analysis, unless otherwise stated.

\subsubsection{Chemical synthesis}

4.1.2.1. General synthetic procedure for preparation of diarylketones (Procedure 1). 1 equivalent of $n \mathrm{BuLi}$ (1.6 M in hexane) was added onto a solution of bromoderivative completely dissolved in dry THF at $-40{ }^{\circ} \mathrm{C}$. After one hour stirring, 0.4 equivalents of carboxylic acid dissolved in dry THF was added and the mixture was warmed to room temperature. After $24 \mathrm{~h}$, ethyl formate, ethyl acetate and water were added. The organic phase was partially evaporated, washed with brine, dried over $\mathrm{Na}_{2} \mathrm{SO}_{4}$, filtered and evaporated to dryness. The products obtained were purified by flash chromatography.

4.1.2.2. General synthetic procedure for preparation of isocombretastatins (Procedure 2). A suspension of the phosphonium salt in dry THF was placed under stirring at $-40{ }^{\circ} \mathrm{C}$ and 0.67 equivalents of $n \mathrm{BuLi}(1.6 \mathrm{M}$ in hexane) were added. After one hour stirring, 0.33 equivalents of carbonyl compound dissolved in dry THF was added and the mixture was warmed to room temperature. Ammonium chloride and ethyl acetate were added $24 \mathrm{~h}$ later, and the organic phase was partially evaporated, washed with brine, dried over $\mathrm{Na}_{2} \mathrm{SO}_{4}$, filtered and evaporated to dryness. The products obtained were purified by flash chromatography.

4.1.2.3. General synthetic procedure for preparation of oximes (Procedure 3). A solution of the carbonyl compound in methanol and 10 equivalents of hydroxylamine hydrochloride and 4 drops of pyridine were refluxed for $24 \mathrm{~h}$. After that, solvent was evaporated and the product was dissolved in dichloromethane and washed with water. The organic phase was washed with brine, dried over anhydrous $\mathrm{Na}_{2} \mathrm{SO}_{4}$, filtered, and concentrated under vacuum. The residue was purified by flash chromatography obtaining the mixture of oximes ( $E$ and $Z$ ).
4.1.2.4. General synthetic procedure for preparation of oxadiazolines (Procedure 4). Hydrazide 12 was dissolved in a solution of EtOH/ water/AcOH (25:5:0.2) and 1 equivalent of aldehyde was added. After $24 \mathrm{~h}$ at $90^{\circ} \mathrm{C}$, the product was extracted with ethyl acetate, washed with brine, dried over $\mathrm{Na}_{2} \mathrm{SO}_{4}$ and filtered. The acylhydrazones were purified by flash chromatography.

The acylhydrazones were dissolved in acetic anhydride and stirred at $160{ }^{\circ} \mathrm{C}$ for one hour. The crude was poured onto ice and extracted with ethyl acetate, washed with sodium bicarbonate until basic $\mathrm{pH}$, and then washed with brine. The organic phases were dried over $\mathrm{Na}_{2} \mathrm{SO}_{4}$, filtered and evaporated to dryness under vacuum. The products were purified by flash chromatography.

4.1.2.5. General synthetic procedure for preparation of combretastatins (Procedure 5). 1.1 equivalents of $n \mathrm{BuLi}$ (1.6 $\mathrm{M}$ in hexane) were added at $-40{ }^{\circ} \mathrm{C}$ to 1.2 equivalents of the corresponding phosphonium salt in dry THF. After one hour stirring, the corresponding aromatic aldehyde was slowly added and the reaction was progressively warmed to room temperature. After $72 \mathrm{~h}$, the crude was poured onto ammonium chloride and extracted with ethyl acetate. The organic layers were washed with brine, dried over $\mathrm{Na}_{2} \mathrm{SO}_{4}$, filtered and evaporated to dryness. Mixtures of $Z$ and $E$ isomers were obtained and separated by flash chromatography.

4.1.2.6. General synthetic procedure for preparation of aldehydes (Procedure 6). Phosphorus oxychloride $(6 \mathrm{mmol}$ per mmol of indole derivative) was added onto dry DMF at $0{ }^{\circ} \mathrm{C}$ and stirred for half an hour. After that, indole derivative was added. Depending on the nature of the bridge, it was heated at $60^{\circ} \mathrm{C}$ for $2-24 \mathrm{~h}$ (phenstatins), or it was kept $2 \mathrm{~h}$ at room temperature (isocombretastatins). The solution was poured onto ice water with sodium acetate. After $24 \mathrm{~h}$ at $4{ }^{\circ} \mathrm{C}$, the precipitate was filtered, redissolved in dichloromethane, dried over anhydrous $\mathrm{Na}_{2} \mathrm{SO}_{4}$, filtered and evaporated to dryness. The products were purified by flash chromatography.

4.1.2.7. General synthetic procedure for preparation of carbonitriles (Procedure 7). 10 equivalents of hydroxylamine hydrochloride and 4 drops of pyridine were added onto a solution of the corresponding aldehyde in methanol and refluxed for $24 \mathrm{~h}$. After that, the solvent was evaporated and the product was dissolved in dichloromethane and washed with water. The organic phase was washed with brine, dried over anhydrous $\mathrm{Na}_{2} \mathrm{SO}_{4}$, filtered, and concentrated under vacuum.

Then, oximes were dissolved in pyridine and an excess of acetic anhydride was added, and stirred for $24-48 \mathrm{~h}$ at $130{ }^{\circ} \mathrm{C}$. The reaction was poured onto ice and subsequently extracted with dichloromethane, washed with $2 \mathrm{~N} \mathrm{HCl}$ and then with $5 \% \mathrm{NaHCO}_{3}$. The organic layers were washed with brine until neutral $\mathrm{pH}$, dried over $\mathrm{Na}_{2} \mathrm{SO}_{4}$, filtered and evaporated to dryness. The products were purified by flash chromatography.

4.1.2.8. 2,6-Dichloropyridine-4-carboxylic acid (1). $45.1 \mathrm{~g}$ of citrazinic acid $(291 \mathrm{mmol})$ and $31 \mathrm{~g}$ of tetramethylammonium chloride (282.8 mmol) in $\mathrm{POCl}_{3}(80 \mathrm{~mL})$ were heated to $90{ }^{\circ} \mathrm{C}$ until complete dissolution. Then, temperature was gradually increased to $140{ }^{\circ} \mathrm{C}$. After $24 \mathrm{~h}$, the mixture was cooled to room temperature and poured on ice. The precipitate was filtered, washed with water and dried under vacuum. The solid was suspended in ethyl acetate, stirred for $15 \mathrm{~min}$, and filtered to remove insoluble citrazinic acid. The organic solution was dried over $\mathrm{Na}_{2} \mathrm{SO}_{4}$ and evaporated, to obtain $42 \mathrm{~g}$ (218.8 mmol, $75.2 \%$ ) of a brown solid corresponding to 1 . M.p. $203-204^{\circ} \mathrm{C}$. IR (KBr): 2600-3300, 1724, 1596, $1547 \mathrm{~cm}^{-1} .{ }^{1} \mathrm{H}$ NMR (200 MHz, DMSO-D $)$ : $7.83(2 \mathrm{H}, \mathrm{s}) .{ }^{13} \mathrm{C}$ NMR (50 MHz, $\left.\mathrm{CD}_{3} \mathrm{OD}\right): 124.0$ (2) (CH), $145.4(\mathrm{C})$, $152.2(2)(\mathrm{C}), 165.0(\mathrm{C})$.

4.1.2.9. 2-Chloro-6-methoxypyridine-4-carboxylic acid (2). $200 \mathrm{~mL}$ of a $25 \%$ solution of sodium methoxide in methanol was added on a solution 


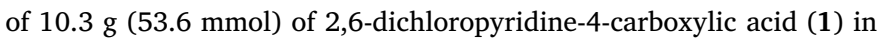
$100 \mathrm{~mL}$ of methanol and refluxed for $24 \mathrm{~h}$. The mixture was cooled to room temperature, filtered off and evaporated. The solid was dissolved in water, acidified with $2 \mathrm{~N} \mathrm{HCl}$ and extracted with ethyl acetate. The organic phase was dried over anhydrous $\mathrm{Na}_{2} \mathrm{SO}_{4}$, filtered and evaporated, to obtain $8.1 \mathrm{~g}(43.2 \mathrm{mmol}, 81 \%)$ of 2-chloro-6methoxypyridine-4-carboxylic acid (2) as a brown amorphous solid. ${ }^{1} \mathrm{H}$ NMR (200 MHz, CD $\left.{ }_{3} \mathrm{OD}\right): 3.87(3 \mathrm{H}, \mathrm{s}), 7.15(1 \mathrm{H}, \mathrm{s}), 7.36(1 \mathrm{H}, \mathrm{s}) .{ }^{13} \mathrm{C}$ NMR (50 MHz, CD $\left.{ }_{3} \mathrm{OD}\right): 54.5\left(\mathrm{CH}_{3}\right), 109.4(\mathrm{CH}), 115.5(\mathrm{CH}), 144.3(\mathrm{C})$, 148.1 (C), 164.1 (C), 164.6 (C).

4.1.2.10. 2-Chloro-6-methylsulfanylpyridine-4-carboxylic acid (3). $50 \mathrm{~mL}$ of a solution of $3.84 \mathrm{~g}(54.8 \mathrm{mmol})$ of sodium methanethiolate in dry DMF was added onto a solution of $7 \mathrm{~g}(36.5 \mathrm{mmol})$ of 2,6dichloropyridine-4-carboxylic acid (1) and $1 \mathrm{~g}$ of $\mathrm{KOH}$ in $100 \mathrm{~mL}$ of dry DMF and refluxed for $24 \mathrm{~h}$. The mixture was cooled to room temperature, poured onto brine and extracted with ethyl acetate. The organic phase was washed with $2 \mathrm{~N} \mathrm{HCl}$ and brine until neutral $\mathrm{pH}$. The organic layer was dried over anhydrous $\mathrm{Na}_{2} \mathrm{SO}_{4}$, filtered and evaporated, obtaining $6.71 \mathrm{~g}(32.9 \mathrm{mmol}, 90.1 \%)$ of 2-chloro-6methylsulfanylpyridine-4-carboxylic acid (3) as a brown amorphous solid. IR (film): 3100, 1706, 1588, $1545 \mathrm{~cm}^{-1}$. ${ }^{1} \mathrm{H}$ NMR $(200 \mathrm{MHz}$, $\left.\mathrm{CD}_{3} \mathrm{OD}\right): 2.46(3 \mathrm{H}, \mathrm{s}), 7.40(1 \mathrm{H}, d, J=1), 7.54(1 \mathrm{H}, d, J=1) .{ }^{13} \mathrm{C} \mathrm{NMR}$ (50 MHz, $\left.\mathrm{CD}_{3} \mathrm{OD}\right): 13.7\left(\mathrm{CH}_{3}\right), 119.4(\mathrm{CH}), 120.3(\mathrm{CH}), 142.2(\mathrm{C})$, 152.6 (C), 163.7 (C), $166.2(\mathrm{C})$.

4.1.2.11. 2,6-Dimethoxypyridine-4-carboxylic acid (4). Acid 1 (4.75 g, $24.7 \mathrm{mmol}$ ) in diglyme was added on $60 \mathrm{~mL}$ of a MeONa/methanol solution. This mixture was refluxed in a Dean Stark apparatus for $24 \mathrm{~h}$. The mixture was cooled to room temperature, filtered and evaporated. The solid was dissolved in water, acidified with $2 \mathrm{~N} \mathrm{HCl}$ and extracted with ethyl acetate. The organic phase was dried over anhydrous $\mathrm{Na}_{2} \mathrm{SO}_{4}$, filtered and evaporated, obtaining $3.01 \mathrm{~g}$ (164 mmol, 66.4\%) of compound 4. M.p. $222-225{ }^{\circ} \mathrm{C}\left(\mathrm{CH}_{2} \mathrm{Cl}_{2} / \mathrm{Hex}\right)$. IR (film): 3354,1704 , $1619 \mathrm{~cm}^{-1} .{ }^{1} \mathrm{H}$ NMR (200 MHz, $\left.\mathrm{CD}_{3} \mathrm{OD}\right): 3.82(6 \mathrm{H}, \mathrm{s}), 6.68(2 \mathrm{H}, \mathrm{s}) .{ }^{13} \mathrm{C}$ NMR (50 MHz, $\left.\mathrm{CD}_{3} \mathrm{OD}\right): 54.1$ (2) $\left(\mathrm{CH}_{3}\right), 102.1$ (2) (CH), 145.0 (C), 165.1 (2) (C), 167.8 (C).

4.1.2.12. 2-Methoxy-6-methylsulfanyl-pyridine-4-carboxylic acid (5). A saturated solution of sodium methoxide/methanol was added on $5.53 \mathrm{~g}$ (27.2 mmol) of 2-chloro-6-methylsulfanylpyridine-4-carboxylic acid in diglyme (50-100 mL) and refluxed for $24 \mathrm{~h}$ using a Dean-Stark trap. After reaction completion, the mixture was cooled to room temperature and diglyme was evaporated. The crude was dissolved in $2 \mathrm{~N} \mathrm{HCl}$ and ethyl acetate, and organic phases were washed with brine, dried over anhydrous $\mathrm{Na}_{2} \mathrm{SO}_{4}$, filtered and evaporated, to obtain $5.10 \mathrm{~g}$ (25.6 mmol, 94\%) of acid 5. M.p. $178-179{ }^{\circ} \mathrm{C}$ (ethyl acetate). IR (film): 1703, 1597, $1557 \mathrm{~cm}^{-1}$. ${ }^{1} \mathrm{H}$ NMR (200 MHz, CD $\left.3 \mathrm{OD}\right): 2.47$ (3H, s), $3.86(3 \mathrm{H}, \mathrm{s}), 6.81(1 \mathrm{H}, \mathrm{s}), 7.16(1 \mathrm{H}, \mathrm{s}) .{ }^{13} \mathrm{C}$ NMR $\left(50 \mathrm{MHz}, \mathrm{CD}_{3} \mathrm{OD}\right)$ : $13.5\left(\mathrm{CH}_{3}\right), 54.3\left(\mathrm{CH}_{3}\right), 106.3(\mathrm{CH}), 113.7(\mathrm{CH}), 142.6(\mathrm{C}), 160.3(\mathrm{C})$, 165.6 (C), 167.4 (C).

\subsubsection{3. (2,6-Dimethoxypyridine-4-yl)-methanol}

(6). $16.4 \quad \mathrm{~g}$ (89.6 mmol) of compound 4 in THF were cooled at $0{ }^{\circ} \mathrm{C}$ and $3.57 \mathrm{~g}$ of $\mathrm{LiAlH}_{4}(89.3 \mathrm{mmol})$ were slowly added. After $1 \mathrm{~h}$ the reaction was allowed to reach room temperature. After $10 \mathrm{~h}$, the reaction was poured onto ethyl acetate, filtered and evaporated to yield $10.9 \mathrm{~g}(64.4 \mathrm{mmol}$, $72 \%)$ of alcohol 6 as a white solid. M.p. $60-63{ }^{\circ} \mathrm{C}\left(\mathrm{CH}_{2} \mathrm{Cl}_{2} / \mathrm{Hex}\right)$. IR (film): $3749,1617,1574 \mathrm{~cm}^{-1} .{ }^{1} \mathrm{H}$ NMR $\left(200 \mathrm{MHz}, \mathrm{CDCl}_{3}\right): 3.91(6 \mathrm{H}$, s); $4.63(2 \mathrm{H}, \mathrm{s}) ; 6.30(2 \mathrm{H}, \mathrm{s}) .{ }^{13} \mathrm{C} \mathrm{NMR}\left(50 \mathrm{MHz}, \mathrm{CDCl}_{3}\right): 53.4\left(\mathrm{CH}_{3}\right)$, $63.3\left(\mathrm{CH}_{2}\right), 98.1$ (2) (CH), 156.1 (2) (C), 163.3 (C). GC-MS m/z (relative intensity, \%): $168\left(\begin{array}{lll}1 & 0 & 0\end{array}\right), 169\left(\mathrm{M}^{+}, 77\right)$.

4.1.2.14. 2-Methoxy-6-(methylsulfanyl)pyridine-4-ylmethanol (7). $1.13 \mathrm{~g}$ $(5.66 \mathrm{mmol})$ of acid $5 \mathrm{in}$ THF were cooled at $0{ }^{\circ} \mathrm{C}$ and $0.32 \mathrm{~g}$ of $\mathrm{LiAlH}_{4}$ $(8.48 \mathrm{mmol})$ were slowly added. After $1 \mathrm{~h}$ the reaction was allowed to reach room temperature and stirred for $10 \mathrm{~h}$. The reaction was poured onto ethyl acetate, filtered and rotary evaporated to yield $0.88 \mathrm{~g}$ (4.72 mmol, 83\%) of alcohol 7 as an oil. IR (film): 3347, 1598, 1559, $\mathrm{cm}^{-1} .{ }^{1} \mathrm{H}$ NMR $\left(200 \mathrm{MHz}, \mathrm{CDCl}_{3}\right): 2.52(3 \mathrm{H}, \mathrm{s}), 3.91(3 \mathrm{H}, \mathrm{s}), 4.55(2 \mathrm{H}$, s), $6.35(1 \mathrm{H}, \mathrm{s}), 6.71(1 \mathrm{H}, \mathrm{s}) .{ }^{13} \mathrm{C} \mathrm{NMR}\left(50 \mathrm{MHz}, \mathrm{CDCl}_{3}\right): 13.3\left(\mathrm{CH}_{3}\right)$, $53.5\left(\mathrm{CH}_{3}\right), 63.1\left(\mathrm{CH}_{2}\right), 102.3(\mathrm{CH}), 111.0(\mathrm{CH}), 153.4(\mathrm{C}), 157.4(\mathrm{C})$, $163.3(\mathrm{C})$.

$\begin{array}{llll}\text { 4.1.2.15. 2,6-Dimethoxypyridine-4-carbaldehyde } & \text { (8). } 33.7 \quad \mathrm{~g}\end{array}$ $(387.4 \mathrm{mmol})$ of $\mathrm{MnO}_{2}$ were added to $10.9 \mathrm{~g}(64.5 \mathrm{mmol})$ of $6 \mathrm{in}$ $500 \mathrm{~mL}$ of methanol and stirred for $72 \mathrm{~h}$ at room temperature. The crude was filtered off and the solvent was evaporated to yield $3.1 \mathrm{~g}$ (18 mmol, 28.8\%) of 8. M.p. (decomp) $\left(\mathrm{CH}_{2} \mathrm{Cl}_{2} / \mathrm{Hex}\right) .{ }^{1} \mathrm{H}$ NMR: 3.96 $(6 \mathrm{H}, \mathrm{s}), 6.71(2 \mathrm{H}, \mathrm{s}), 9.93(1 \mathrm{H}, \mathrm{s}) .{ }^{13} \mathrm{C}$ NMR: 54.0 (2) $\left(\mathrm{CH}_{3}\right), 100.7$ (2) (CH), 147.5 (2) (C), 164.3 (C), 191.3 (CH). IR (film): 1711, 1570, $1458 \mathrm{~cm}^{-1}$. GC-MS $\mathrm{m} / \mathrm{z}$ (relative intensity, \%): $166(88), 167\left(\mathrm{M}^{+}\right.$, 100).

\subsubsection{4-(Bromomethyl)-2-methoxy-6-(methylsulfanyl)pyridine}

(9). $0.88 \mathrm{~g}$ (4.72 mmol) of 2-methoxy-6-(methylsulfanyl)pyridine-4ylmethanol (7) in $5 \mathrm{~mL}$ of acetic acid were cooled to $0{ }^{\circ} \mathrm{C}$ and $20 \mathrm{~mL}$ of $\mathrm{HBr}$ in acetic acid were slowly added. After $1 \mathrm{~h}$ the reaction was allowed to reach room temperature and stirred for $10 \mathrm{~h}$. The reaction was poured onto ice and extracted with ethyl acetate. The organic layers were washed with $5 \% \mathrm{NaHCO}_{3}$ and brine, dried over anhydrous $\mathrm{Na}_{2} \mathrm{SO}_{4}$, filtered and evaporated to yield $0.98 \mathrm{~g}$ (3.97 mmol, 84\%) of alcohol 4-(bromomethyl)-2-methoxy-6-(methylsulfanyl)pyridine (9) as

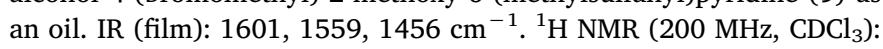
$2.53(3 \mathrm{H}, \mathrm{s}), 3.92(3 \mathrm{H}, \mathrm{s}), 4.98(2 \mathrm{H}, \mathrm{s}), 6.34(1 \mathrm{H}, \mathrm{s}), 6.70(1 \mathrm{H}, \mathrm{s}) .{ }^{13} \mathrm{C}$ NMR (50 MHz, $\left.\mathrm{CDCl}_{3}\right)$ : $12.9\left(\mathrm{CH}_{3}\right), 53.2\left(\mathrm{CH}_{3}\right), 64.0\left(\mathrm{CH}_{2}\right), 103.3(\mathrm{CH})$, 111.5 (CH), 147.9 (C), 157.7 (C), 163.8 (C).

\subsubsection{7. (2-Methoxy-6-(methylsulfanyl)pyridine-4-ylmethyl)}

triphenylphosphonium bromide (10). $1.21 \mathrm{~g}$ (4.37 $\mathrm{mmol}$ of $\mathrm{PPh}_{3}$ were added to a solution of $0.98 \mathrm{~g}(3.97 \mathrm{mmol})$ of compound 9 in toluene. After $24 \mathrm{~h}$, the crude was filtered to obtain $0.38 \mathrm{~g}(0.73 \mathrm{mmol}, 19 \%)$ of compound 10 as a white solid. M.p. $>220{ }^{\circ} \mathrm{C}$ (Toluene). ${ }^{1} \mathrm{H}$ NMR (200 MHz, $\mathrm{CDCl}_{3}$ ): $2.13(3 \mathrm{H}, \mathrm{s}), 3.78(3 \mathrm{H}, \mathrm{s}), 5.50(2 \mathrm{H}, \mathrm{d}, J=16.2$ ), $6.27(1 \mathrm{H}, \mathrm{s}), 6.54(1 \mathrm{H}, \mathrm{s}), 7.70(15 \mathrm{H}, \mathrm{m})$.

4.1.2.18. 1-Methyl-1H-indole-5-carbaldehyde (11). $1.04 \mathrm{~g}$ (26 mmol) of $\mathrm{NaOH}$ and $20 \mathrm{mg}$ of $n-\mathrm{Bu}_{4} \mathrm{NHSO}_{4}$ were added to a stirred solution of $1 \mathrm{H}$ indole-5-carbaldehyde $(2.0 \mathrm{~g}, 13.8 \mathrm{mmol})$ in $40 \mathrm{~mL}$ of dry dichloromethane. After $1 \mathrm{~h}$ at room temperature $3 \mathrm{~mL}(40.2 \mathrm{mmol})$ of methyl iodide were added and the reaction was heated at $50{ }^{\circ} \mathrm{C}$. After $48 \mathrm{~h}$, the reaction mixture was concentrated, re-dissolved in dichloromethane, washed with brine, dried over anhydrous $\mathrm{Na}_{2} \mathrm{SO}_{4}$, filtered and concentrated in vacuum to obtain $1.10 \mathrm{~g}(50.1 \%)$ of 1 methyl- $1 \mathrm{H}$-indole-5-carbaldehyde (11): M.p. $85-86{ }^{\circ} \mathrm{C}$ (ether). ${ }^{1} \mathrm{H}$ NMR $\left(200 \mathrm{MHz}, \mathrm{CDCl}_{3}\right): 3.76(3 \mathrm{H}, \mathrm{s}), 6.55(1 \mathrm{H}, \mathrm{d}, J=3.3), 7.10(1 \mathrm{H}, \mathrm{d}$, $J=3.3$ ), $7.41(1 \mathrm{H}, \mathrm{d}, J=8.8), 7.80(1 \mathrm{H}, \mathrm{dd}, J=8.8$ and 1.9$), 8.05$ $(1 \mathrm{H}, \mathrm{d}, J=1.9), 9.92(1 \mathrm{H}, \mathrm{s}) .{ }^{13} \mathrm{C}$ NMR $\left(50 \mathrm{MHz}, \mathrm{CDCl}_{3}\right): 32.6\left(\mathrm{CH}_{3}\right)$, $103.1(\mathrm{CH}), 109.8(\mathrm{CH}), 121.4(\mathrm{CH}), 126.1(\mathrm{CH}), 128.2(\mathrm{C}), 129.1(\mathrm{C})$, $130.9(\mathrm{CH}), 139.8(\mathrm{C}), 192.3(\mathrm{CH})$.

4.1.2.19. 2-methylsulfanyl-6- methoxypyridinecarbohydrazide (12). A solution of $3.19 \mathrm{~mL}(65.8 \mathrm{mmol})$ of hydrazine in dichloromethane was added to $2.0 \mathrm{~g}(13.16 \mathrm{mmol})$ of compound $6,5.045 \mathrm{~g}(26.32 \mathrm{mmol})$ of EDCI, and $804 \mathrm{mg}(6.48 \mathrm{mmol})$ of 4-DMAP in dichloromethane at room temperature. After $24 \mathrm{~h}$, dichloromethane was evaporated, residue was dissolved in ethyl acetate and washed with $4 \% \mathrm{NaOH}$, $2 \mathrm{~N} \mathrm{HCl}$ and brine, dried over anhydrous $\mathrm{Na}_{2} \mathrm{SO}_{4}$, filtered and evaporated, to obtain $1.58 \mathrm{~g}$ (7.39 mmol, 56\%) of compound 12 as a powder. IR (film): $\left.3309,1645,1549 \mathrm{~cm}^{-1} .{ }^{1} \mathrm{H} \mathrm{NMR} \mathrm{(200} \mathrm{MHz}, \mathrm{CDCl}_{3}\right)$ : $2.00(2 \mathrm{H}, \mathrm{s}), 2.51(3 \mathrm{H}, \mathrm{s}), 3.90(3 \mathrm{H}, \mathrm{s}), 6.68(1 \mathrm{H}, \mathrm{d}, J=1.1), 7.05(1 \mathrm{H}$, d, $J=1.1), 7.89(1 \mathrm{H}, \mathrm{s}) .{ }^{13} \mathrm{C}$ NMR $\left(50 \mathrm{MHz}, \mathrm{CDCl}_{3}\right): 13.4\left(\mathrm{CH}_{3}\right), 53.9$ 
$\left(\mathrm{CH}_{3}\right), 103.0(\mathrm{CH}), 110.9(\mathrm{CH}), 142.6$ (C), $159.2(\mathrm{C}), 164.2(\mathrm{C}), 166.7$ (C). HRMS $\left(\mathrm{C}_{8} \mathrm{H}_{11} \mathrm{~N}_{3} \mathrm{O}_{2} \mathrm{~S}\right)$ : calcd $236.0464\left(\mathrm{M}+\mathrm{Na}^{+}\right)$, found 236.0468 .

\subsubsection{2,6-dimethoxy-4-(3,4,5-trimethoxystyryl)-pyridine}

(13). Prepared according to procedure 5: $27 \mathrm{mg}(0.08 \mathrm{mmol}, 2.9 \%)$ of 13(Z) and $15 \mathrm{mg}(0.05 \mathrm{mmol}, 1.9 \%)$ of $13(E)$.

(Z)-2,6-dimethoxy-4-(3,4,5-trimethoxystyryl)-pyridine (13): Oil. IR (film): $1609,1152 \mathrm{~cm}^{-1} .{ }^{1} \mathrm{H}$ NMR $\left(200 \mathrm{MHz}, \mathrm{CDCl}_{3}\right): 3.69(6 \mathrm{H}$, s), $3.84(3 \mathrm{H}, \mathrm{s}), 3.85(6 \mathrm{H}, \mathrm{s}), 6.22(2 \mathrm{H}, \mathrm{s}), 6.41(1 \mathrm{H}, \mathrm{d}, J=12.0), 6.48$ $(2 \mathrm{H}, \mathrm{s}), 6.6(1 \mathrm{H}, \mathrm{d}, J=12.0) .{ }^{13} \mathrm{C}$ NMR $\left(200 \mathrm{MHz}, \mathrm{CDCl}_{3}\right): 53.6(2)$ $\left(\mathrm{CH}_{3}\right), 56.0$ (2) $\left(\mathrm{CH}_{3}\right), 60.9\left(\mathrm{CH}_{3}\right), 100.9$ (2) $(\mathrm{CH}), 106.3(2)(\mathrm{CH})$, $127.6(\mathrm{CH}), 131.6(\mathrm{C}), 132.9(\mathrm{CH}), 150.6(\mathrm{C}), 152.9$ (2) (C), 153.5 (C), 163.5 (2) (C). HRMS $\left(\mathrm{C}_{18} \mathrm{H}_{21} \mathrm{NO}_{5}\right)$ : calcd $332.1492\left(\mathrm{M}+\mathrm{H}^{+}\right)$, found 332.1507.

(E)-2,6-dimethoxy-4-(3,4,5-trimethoxystyryl)-pyridine (13): Oil. IR (film): 1609, $1058 \mathrm{~cm}^{-1} .{ }^{1} \mathrm{H}$ NMR $\left(200 \mathrm{MHz}, \mathrm{CDCl}_{3}\right): 3.87(3 \mathrm{H}$, s); $3.91\left(6 \mathrm{H}, \mathrm{s}, \mathrm{OCH}_{3}\right) ; 3.93(6 \mathrm{H}, \mathrm{s}) ; 6.40(2 \mathrm{H}, \mathrm{s}) ; 6.73(2 \mathrm{H}, \mathrm{s}) ; 6.84(1 \mathrm{H}$, d; $J=16.0) ; 7.13(1 \mathrm{H}, \mathrm{d} ; J=16.0) .{ }^{13} \mathrm{C}$ NMR $\left(50 \mathrm{MHz}, \mathrm{CDCl}_{3}\right): 53.6$ (2) $\left(\mathrm{CH}_{3}\right) ; 56.2$ (2) $\left(\mathrm{CH}_{3}\right) ; 61.0\left(\mathrm{CH}_{3}\right) ; 98.5$ (2) $(\mathrm{CH}) ; 104.1$ (2) $(\mathrm{CH})$; 125.9 (CH); 132.1 (C); 132.5 (CH); 149.9 (C); 153.5 (2) (C); 155.1 (C); 163.8 (2) (C). HRMS $\left(\mathrm{C}_{18} \mathrm{H}_{21} \mathrm{NO}_{5}\right)$ : calcd $332.1492\left(\mathrm{M}+\mathrm{H}^{+}\right)$, found 332.1505 .

4.1.2.21. 2,6-dimethoxy-4-(4-methoxystyryl)-pyridine (14). Prepared according to procedure 5: $286 \mathrm{mg}(1.05 \mathrm{mmol}, 29.2 \%)$ of $14(\mathrm{Z})$ and $119 \mathrm{mg}(0.44 \mathrm{mmol}, 12.2 \%)$ of $14(E)$.

(Z)-2,6-dimethoxy-4-(4-methoxystyryl)-pyridine (14): Oil. IR (film): 1608, $1511 \mathrm{~cm}^{-1} \cdot{ }^{1} \mathrm{H} \mathrm{NMR}\left(200 \mathrm{MHz}, \mathrm{CDCl}_{3}\right): 3.78$ (3H, s), 3.85 $(6 \mathrm{H}, \mathrm{s}), 6.19$ (2H, s), $6.33(1 \mathrm{H}, \mathrm{d}, J=12.0), 6.62(1 \mathrm{H}, \mathrm{d}, J=12.0)$, $6.76(2 \mathrm{H}, \mathrm{d}, J=9.0), 7.18(2 \mathrm{H}, \mathrm{d}, J=9.0) .{ }^{13} \mathrm{C} \mathrm{NMR}(200 \mathrm{MHz}$, $\left.\mathrm{CDCl}_{3}\right)$ : 53.4 (2) $\left(\mathrm{CH}_{3}\right), 55.1\left(\mathrm{CH}_{3}\right), 100.9(2)(\mathrm{CH}), 113.7(2)(\mathrm{CH})$, $126.4(\mathrm{CH}), 128.8(\mathrm{C}), 130.3(2)(\mathrm{CH}), 132.7(\mathrm{CH}), 150.8(\mathrm{C}), 159.2(\mathrm{C})$, 163.5 (2) (C). HRMS $\left(\mathrm{C}_{16} \mathrm{H}_{17} \mathrm{NO}_{3}\right)$ : calcd $272.1281\left(\mathrm{M}+\mathrm{H}^{+}\right)$, found 272.1283 .

(E)-2,6-dimethoxy-4-(4-methoxystyryl)-pyridine (14): Oil. IR (film): $1606 \mathrm{~cm}^{-1} .{ }^{1} \mathrm{H}$ NMR (200 MHz, $\left.\mathrm{CDCl}_{3}\right): 3.82(3 \mathrm{H}, \mathrm{s}), 3.93(6 \mathrm{H}$, s), $6.39(2 \mathrm{H}, \mathrm{s}), 6.80(1 \mathrm{H}, \mathrm{d}, J=16.0), 6,89(2 \mathrm{H}, \mathrm{d}, J=8.0)$; $7.16(2 \mathrm{H}$, d, $J=16.0), 7.45(2 \mathrm{H}, \mathrm{d}, J=8.0) .{ }^{13} \mathrm{C}$ NMR $\left(50 \mathrm{MHz}, \mathrm{CDCl}_{3}\right): 53.5$ (2) $\left(\mathrm{CH}_{3}\right), 55.3\left(\mathrm{CH}_{3}\right), 98.3(2)(\mathrm{CH}), 114.2(2)(\mathrm{CH}), 124.2(\mathrm{CH}), 128.4(2)$ (CH), 129.1 (C), 132.1 (CH), 150.4 (C), 160.0 (C), 163.8 (2) (C). HRMS $\left(\mathrm{C}_{16} \mathrm{H}_{17} \mathrm{NO}_{3}\right)$ : calcd $272.1281\left(\mathrm{M}+\mathrm{H}^{+}\right)$, found 272.1289

4.1.2.22. 2,6-dimethoxy-4-(2-naphth-2-ylvinyl)-pyridine (15). Prepared according to procedure 5: $80 \mathrm{mg}(0.27 \mathrm{mmol}, 7.5 \%)$ of $15(Z)$ and $140 \mathrm{mg}$ (0.48 mmol, 13.3\%) of 15(E).

(Z)-2,6-dimethoxy-4-(2-naphth-2-ylvinyl)-pyridine (15): Oil. IR (film): 1609, $1553 \mathrm{~cm}^{-1} .{ }^{1} \mathrm{H} \mathrm{NMR}\left(200 \mathrm{MHz}, \mathrm{CDCl}_{3}\right): 3.82(6 \mathrm{H}, \mathrm{s}), 6.20$ $(2 \mathrm{H}, \mathrm{s}), 6.52(1 \mathrm{H}, \mathrm{d}, J=12.0), 6.86(1 \mathrm{H}, \mathrm{d}, J=12.0) ; 7,3-7,8$ (7H, m). ${ }^{13} \mathrm{C}$ NMR (200 MHz, $\left.\mathrm{CDCl}_{3}\right): 53.5$ (2) $\left(\mathrm{CH}_{3}\right), 100.9$ (2) (CH), $126.2(2)$ $(\mathrm{CH}), 126.7(\mathrm{CH}), 127.7$ (2) $(\mathrm{CH}), 128.1(\mathrm{CH}), 128.4(2)(\mathrm{CH})$, 132.7(C), 132.8 (C), 133.2 (CH), 133.9 (C), 150.4 (C), 163.5 (2) (C). HRMS $\left(\mathrm{C}_{16} \mathrm{H}_{17} \mathrm{NO}_{3}\right)$ : calcd $292.1332\left(\mathrm{M}+\mathrm{H}^{+}\right)$, found 292.1341

(E)-2,6-dimethoxy-4-(2-naphth-2-ylvinyl)-pyridine (15): Oil. IR (film): 1550, $1607 \mathrm{~cm}^{-1} .{ }^{1} \mathrm{H}$ NMR $\left(200 \mathrm{MHz}, \mathrm{CDCl}_{3}\right): 3.96(6 \mathrm{H}, \mathrm{s}), 6.47$ (2H, s), 7.07 (1H, d, $J=16.0), 7.38(1 \mathrm{H}, \mathrm{d}, J=16.0), 7.40-7.90(7 \mathrm{H}$, m). ${ }^{13} \mathrm{C}$ NMR (50 MHz, $\left.\mathrm{CDCl}_{3}\right): 53.6(2)\left(\mathrm{CH}_{3}\right), 98.6(2)(\mathrm{CH}), 123.5$ (2) $(\mathrm{CH}), 126.4(\mathrm{CH}), 126.8(\mathrm{CH}), 127.8(2)(\mathrm{CH}), 128.2(\mathrm{CH}), 128.5(\mathrm{CH})$ 132.6 (CH), 133.5 (C), 133.6 (C), 133.9 (C), 150.0 (C), 163.8 (2) (C). HRMS $\left(\mathrm{C}_{16} \mathrm{H}_{17} \mathrm{NO}_{3}\right)$ : calcd 292.1332 $\left(\mathrm{M}+\mathrm{H}^{+}\right)$, found 292.1335.

4.1.2.23. 2-methoxy-4-(4-methoxystyryl)-6-(methylsulfanyl)pyridine (16). Prepared according to procedure 5: $11 \mathrm{mg}(0.04 \mathrm{mmol}, 10 \%)$ of $16(Z)$ as an oil and $43 \mathrm{mg}(0.15 \mathrm{mmol}, 40 \%)$ of a $1: 1$ mixture of 16(Z $+\boldsymbol{E}$ ). IR (film): $1587,1538 \mathrm{~cm}^{-1} \cdot{ }^{1} \mathrm{H}$ NMR $\left(200 \mathrm{MHz}, \mathrm{CDCl}_{3}, Z\right.$ Isomer): $2.45(3 \mathrm{H}, \mathrm{s}), 3.79(3 \mathrm{H}, \mathrm{s}), 3.89(3 \mathrm{H}, \mathrm{s}), 6.28(1 \mathrm{H}, \mathrm{d}, J=12.0)$,
$6.29(1 \mathrm{H}, \mathrm{s}), 6.62(1 \mathrm{H}, \mathrm{d}, J=12.0), 6.63(1 \mathrm{H}, \mathrm{s}), 6.77(2 \mathrm{H}, \mathrm{d}, J=8.9)$, 7.17 (2H, d, $J=8.9$ ). ${ }^{13} \mathrm{C}$ NMR (50 $\mathrm{MHz}, \mathrm{CDCl}_{3}, Z+E$ Isomers): 13.4 $\left(\mathrm{CH}_{3}\right), 53.5\left(\mathrm{CH}_{3}\right), 5.4\left(\mathrm{CH}_{3}\right), 102.6(\mathrm{CH}), 105.0(\mathrm{CH}), 111.0(\mathrm{CH})$, $113.4(\mathrm{CH}), 113.8(2)(\mathrm{CH}), 114.3(2)(\mathrm{CH}), 123.8(\mathrm{CH}), 125.9(\mathrm{CH})$, 128.4 (2) (CH), $129.0(\mathrm{C}), 130.3(2)(\mathrm{CH}), 132.5(\mathrm{CH}), 133.2(\mathrm{CH})$, 148.0 (C), 148.5 (C), 157.4 (C), 159.2 (C), 160.1 (C), 164.4 (C). HRMS $\left(\mathrm{C}_{16} \mathrm{H}_{17} \mathrm{NO}_{2} \mathrm{~S}\right)$ : calcd $310.0872\left(\mathrm{M}+\mathrm{Na}^{+}\right)$, found 310.0874. HPLC $(Z$ Isomer): $\mathrm{C}_{8} \mathrm{t}_{\mathrm{R}}: 20.74 \mathrm{~min}$.

4.1.2.24. 5-(2-(2-methoxy-6-(methylsulfanyl)pyridin-4-yl)vinyl)-1methyl-1H-indole (17). Prepared according to procedure 5: $4.5 \mathrm{mg}$ $(0.01 \mathrm{mmol}, 4 \%)$ of $\mathbf{1 7}(\mathrm{Z})$ as an oil, and $17 \mathrm{mg}(0.05 \mathrm{mmol}, 16 \%)$ of a $1: 1$ mixture of $17(Z+E)$. IR (film): $1587,1541 \mathrm{~cm}^{-1} \cdot{ }^{1} \mathrm{H}$ NMR (200 MHz, $\mathrm{CDCl}_{3}, Z$ Isomer): $2.41(3 \mathrm{H}, \mathrm{s}), 3.77(3 \mathrm{H}, \mathrm{s}), 3.87(3 \mathrm{H}, \mathrm{s})$, $6.30(1 \mathrm{H}, \mathrm{d}, J=12.0), 6.41(1 \mathrm{H}, \mathrm{d}, J=3.2), 6.69(1 \mathrm{H}, \mathrm{s}), 6.78(1 \mathrm{H}, \mathrm{s})$, 6.84 (1H, d, $J=12.0$ ), $7.02(1 \mathrm{H}, \mathrm{d}, J=3.2), 7.15$ ( $1 \mathrm{H}, \mathrm{d}, \mathrm{J}=8.6$ ), $7.17(1 \mathrm{H}, \mathrm{d}, \mathrm{J}=8.6), 7.53(1 \mathrm{H}, \mathrm{s}) .{ }^{13} \mathrm{C}$ NMR $\left(50 \mathrm{MHz}, \mathrm{CDCl}_{3}, Z+E\right.$ Isomers): $13.3\left(\mathrm{CH}_{3}\right), 32.0\left(\mathrm{CH}_{3}\right), 53.4\left(\mathrm{CH}_{3}\right), 101.4(\mathrm{CH}), 101.6(\mathrm{CH})$, $102.4(\mathrm{CH}), 103.5(\mathrm{CH}), 105.1(\mathrm{CH}), 108.9(\mathrm{CH}), 109.5(\mathrm{CH}), 111.0$ $(\mathrm{CH}), 111.8(\mathrm{CH}), 113.5(\mathrm{CH}), 120.4(\mathrm{CH}), 120.6(\mathrm{CH}), 121.7(\mathrm{CH})$, $122.7(\mathrm{CH}), 122.9(\mathrm{CH}), 125.0(\mathrm{CH}), 127.3(\mathrm{C}), 127.8(\mathrm{C}), 128.7(\mathrm{C})$, $129.3(\mathrm{CH}), 129.6(\mathrm{CH}), 134.4(\mathrm{CH}), 135.1(\mathrm{CH}), 148.4(\mathrm{C}), 164.0(\mathrm{C})$, $164.3(\mathrm{C})$. HRMS $\left(\mathrm{C}_{18} \mathrm{H}_{18} \mathrm{~N}_{2} \mathrm{OS}\right)$ : calcd $311.1212\left(\mathrm{M}+\mathrm{H}^{+}\right)$, found 311.1206. HPLC ( $Z$ isomer): $C_{18} t_{R}: 24.04 \mathrm{~min}$.

\subsubsection{2,6-dimethoxy-4-(3,4,5-trimethoxyphenethyl)-pyridine}

(18). $3 \mathrm{mg}$ of $5 \% \mathrm{Pd}(\mathrm{C})$ were added to $25 \mathrm{mg}$ of 2,6-dimethoxy-4(3,4,5-trimethoxystyryl)-pyridine (13) in $20 \mathrm{~mL}$ of ethanol under $\mathrm{H}_{2}$ atmosphere. After $18 \mathrm{~h}$, the reaction was filtered through celite ${ }^{\circledast}$ and evaporated to yield $20 \mathrm{mg}(0.06 \mathrm{mmol}, 75 \%)$ of 2,6-dimethoxy-4(3,4,5-trimethoxyphenethyl)-pyridine (18) as an oil. IR (film): 1612, $1566 \mathrm{~cm}^{-1} .{ }^{1} \mathrm{H}$ NMR (200 MHz, $\mathrm{CDCl}_{3}$ ): 2.81 (4H, s); 3.81 (9H, s); 3.88 $(6 \mathrm{H}, \mathrm{s}), 6.14(2 \mathrm{H}, \mathrm{s}), 6.37(2 \mathrm{H}, \mathrm{s}) .{ }^{13} \mathrm{C}$ NMR $\left(50 \mathrm{MHz}, \mathrm{CDCl}_{3}\right): 36.9$ $\left(\mathrm{CH}_{2}\right), 37.2\left(\mathrm{CH}_{2}\right), 53.5(2)\left(\mathrm{CH}_{3}\right), 56.1(2)\left(\mathrm{CH}_{3}\right), 60.9\left(\mathrm{CH}_{3}\right), 101.1(2)$ (CH), 105.4 (2) (CH), 136.9 (C), 153.2 (2) (C), 156.0 (C), 163.4 (2) (C). HRMS $\left(\mathrm{C}_{18} \mathrm{H}_{23} \mathrm{NO}_{5}\right)$ : calcd $334.1648\left(\mathrm{M}+\mathrm{H}^{+}\right)$, found 334.1658.

4.1.2.26. 2,6-dimethoxy-4-(4-methoxyphenethyl)-pyridine (19). $15 \mathrm{mg}$ of $5 \% \mathrm{Pd}(\mathrm{C})$ were added to $200 \mathrm{mg}$ of 2,6-dimethoxy-4-(4methoxystyryl)-pyridine (14) in $20 \mathrm{~mL}$ of ethanol under $\mathrm{H}_{2}$ atmosphere. After $18 \mathrm{~h}$, the reaction was filtered through celite ${ }^{\circledast}$ and evaporated to yield $184 \mathrm{mg}$ (0.67 mmol, 91\%) of 2,6-dimethoxy-4-(4methoxyphenethyl)-pyridine (19) as an oil. IR (film): $1619,1513 \mathrm{~cm}^{-1}$. ${ }^{1} \mathrm{H}$ NMR (200 MHz, $\mathrm{CDCl}_{3}$ ): 2.80-2.82 (4H, m), $3.76(3 \mathrm{H}, \mathrm{s}), 3.89(6 \mathrm{H}$, s), $6.14(2 \mathrm{H}, \mathrm{s}), 6.81(2 \mathrm{H}, \mathrm{d}, J=8.6), 7.08(2 \mathrm{H}, \mathrm{d}, J=8.6) .{ }^{13} \mathrm{C} \mathrm{NMR}$ $\left(50 \mathrm{MHz}, \mathrm{CDCl}_{3}\right): 35.6\left(\mathrm{CH}_{2}\right), 37.4\left(\mathrm{CH}_{2}\right), 53.4(2)\left(\mathrm{CH}_{3}\right), 55.2\left(\mathrm{CH}_{3}\right)$, $101.1(2)(\mathrm{CH}), 113.8$ (2) (CH), $129.3(2)(\mathrm{CH}), 133.2(\mathrm{C}), 156.3(\mathrm{C})$, 158.0 (C), 163.3 (2) (C). HRMS $\left(\mathrm{C}_{16} \mathrm{H}_{21} \mathrm{NO}_{3}\right)$ : calcd 274.1438 $\left(\mathrm{M}+\mathrm{H}^{+}\right)$, found 274.1451 .

4.1.2.27. 2,6-dimethoxy-4-(2-(naphth-2-yl)ethyl)-pyridine (20). $8 \mathrm{mg}$ of $5 \% \mathrm{Pd}(\mathrm{C})$ were added to $100 \mathrm{mg}(0.34 \mathrm{mmol})$ of 2,6-dimethoxy-4-(2naphth-2-ylvinyl)-pyridine (15) in $35 \mathrm{~mL}$ of ethanol $\mathrm{H}_{2}$ atmosphere. After $16 \mathrm{~h}$, the reaction was filtered through celite ${ }^{\circledR}$ and evaporated to yield $83 \mathrm{mg}(0.28 \mathrm{mmol}, 82 \%)$ of 2,6-dimethoxy-4-(2-(naphth-2-yl) ethyl)-pyridine (20) as an oil. IR (film): $1566 \mathrm{~cm}^{-1} .{ }^{1} \mathrm{H} \mathrm{NMR} \mathrm{(200} \mathrm{MHz,}$ $\left.\mathrm{CDCl}_{3}\right)$ : $2.94-3.12(4 \mathrm{H}, \mathrm{m}), 3.91(6 \mathrm{H}, \mathrm{s}), 6.21(2 \mathrm{H}, \mathrm{s}), 7.31-7.81(7 \mathrm{H}$, m). ${ }^{13} \mathrm{C}$ NMR (50 MHz, $\left.\mathrm{CDCl}_{3}\right): 36.7\left(\mathrm{CH}_{2}\right), 37.1\left(\mathrm{CH}_{2}\right), 53.5(2)\left(\mathrm{CH}_{3}\right)$, $101.1(\mathrm{CH}), 125.4(\mathrm{CH}), 126.0(\mathrm{CH}), 126.5(\mathrm{CH}), 127.2(\mathrm{CH}), 127.6$ (CH), $127.7(\mathrm{CH}), 128.1(\mathrm{CH}), 132.2(\mathrm{C}), 133.7(\mathrm{C}), 138.7(\mathrm{C}), 156.1$ (C), 163.4 (2) (C). HRMS $\left(\mathrm{C}_{19} \mathrm{H}_{20} \mathrm{NO}_{2}\right)$ : calcd $294.1488\left(\mathrm{M}+\mathrm{H}^{+}\right)$, found 294.1498.

4.1.2.28. 1-(2-(4-(dimethylamino)phenyl)-5-(2-methoxy-6(methylsulfanyl)pyridin-4-yl)-1,3,4-oxadiazol-3(2H)-yl)ethanone (21). Prepared according to procedure 4: $82 \mathrm{mg}(0.21 \mathrm{mmol}, 32 \%)$. 
Oil. IR (film): $1603,1550 \mathrm{~cm}^{-1} .{ }^{1} \mathrm{H}$ NMR (200 MHz, $\left.\mathrm{CDCl}_{3}\right): 2.34(3 \mathrm{H}$, s), $2.57(3 \mathrm{H}, \mathrm{s}), 2.96(6 \mathrm{H}, \mathrm{s}), 3.97(3 \mathrm{H}, \mathrm{s}), 6.69(2 \mathrm{H}, \mathrm{d}, J=8.6), 6.82$ $(1 \mathrm{H}, \mathrm{d}, J=0.7), 7.00(1 \mathrm{H}, \mathrm{s}), 7.20(1 \mathrm{H}, \mathrm{d}, J=0.7), 7.29(2 \mathrm{H}, \mathrm{d}$, $J=8.6) .{ }^{13} \mathrm{C}$ NMR $\left(50 \mathrm{MHz}, \mathrm{CDCl}_{3}\right): 13.4\left(\mathrm{CH}_{3}\right), 21.6\left(\mathrm{CH}_{3}\right), 40.4(2)$ $\left(\mathrm{CH}_{3}\right), 53.9\left(\mathrm{CH}_{3}\right), 93.6(\mathrm{CH}), 102.8(\mathrm{CH}), 110.5(\mathrm{CH}), 112.2(2)(\mathrm{CH})$, 123.2 (C), 127.7 (2) (CH), 135.1 (C), 151.6 (C), 153.8 (C), 158.8 (C), 164.1 (C), 167.8 (C). HRMS $\left(\mathrm{C}_{19} \mathrm{H}_{22} \mathrm{~N}_{4} \mathrm{O}_{3} \mathrm{~S}\right)$ : calcd 409.1304 $\left(\mathrm{M}+\mathrm{Na}^{+}\right)$, found 409.1320. HPLC: $\mathrm{C}_{8} \mathrm{t}_{\mathrm{R}}: 4.032 \mathrm{~min}$.

\subsubsection{1-(5-(2-methoxy-6-(methylthio)pyridin-4-yl)-2-(4-}

methoxyphenyl)-1,3,4-oxadiazol-3(2H)-yl)ethanone (22). Prepared according to procedure 4: $118 \mathrm{mg}(0.32 \mathrm{mmol}, 96 \%)$. Amorphous powder. IR (KBr): 1665, 1610, $\left.1555 \mathrm{~cm}^{-1} .{ }^{1} \mathrm{H} \mathrm{NMR} \mathrm{(200} \mathrm{MHz}, \mathrm{CDCl}_{3}\right)$ : $2.34(3 \mathrm{H}, \mathrm{s}), 2.57(3 \mathrm{H}, \mathrm{s}), 3.79(3 \mathrm{H}, \mathrm{s}), 3.97(3 \mathrm{H}, \mathrm{s}), 6.81(1 \mathrm{H}, \mathrm{d}$, $J=1.1), 6.90$ (2H, d, $J=8.6), 7.02(1 \mathrm{H}, \mathrm{s}), 7.19(1 \mathrm{H}, \mathrm{d}, J=1.1), 7.37$ $(2 \mathrm{H}, \mathrm{d}, J=8.6) .{ }^{13} \mathrm{C}$ NMR $\left(50 \mathrm{MHz}, \mathrm{CDCl}_{3}\right): 13.4\left(\mathrm{CH}_{3}\right), 21.5\left(\mathrm{CH}_{3}\right)$, $53.9\left(\mathrm{CH}_{3}\right), 55.4\left(\mathrm{CH}_{3}\right), 93.0(\mathrm{CH}), 102.8(\mathrm{CH}), 110.4(\mathrm{CH}), 114.3(2)$ (CH), 128.1 (2) (CH), 128.3 (C), 134.9 (C), 153.8 (C), 158.9 (C), 160.9 (C), 164.1 (C), 167.9 (C). HRMS $\left(\mathrm{C}_{18} \mathrm{H}_{19} \mathrm{~N}_{3} \mathrm{O}_{4} \mathrm{~S}\right)$ : calcd 396.0988 $\left(\mathrm{M}+\mathrm{Na}^{+}\right)$, found 396.0987. HPLC: $\mathrm{C}_{8} \mathrm{t}_{\mathrm{R}}: 20.59 \mathrm{~min}$.

4.1.2.30. 1-(5-(2-methoxy-6-(methylthio)pyridin-4-yl)-2-(1-methyl-1Hindol-5-yl)-1,3,4-oxadiazol-3(2H)-yl)ethanone (23). Prepared according to procedure 4: $133 \mathrm{mg}(0.34 \mathrm{mmol}, 46 \%)$. Amorphous powder. IR (film): 1672, 1625, $1596 \mathrm{~cm}^{-1} .{ }^{1} \mathrm{H} \mathrm{NMR}\left(200 \mathrm{MHz}, \mathrm{CDCl}_{3}\right): 2.38(3 \mathrm{H}$, s), $2.58(3 \mathrm{H}, \mathrm{s}), 3.76(3 \mathrm{H}, \mathrm{s}), 3.97(3 \mathrm{H}, \mathrm{s}), 6.49(1 \mathrm{H}, \mathrm{d}, J=3.2), 6.85$ $(1 \mathrm{H}, \mathrm{s}), 7.07(1 \mathrm{H}, \mathrm{d}, J=3.2), 7.19(1 \mathrm{H}, \mathrm{s}), 7.23(1 \mathrm{H}, \mathrm{s}), 7.30(2 \mathrm{H}, \mathrm{bd})$, $7.72(1 \mathrm{H}, \mathrm{bs}) .{ }^{13} \mathrm{C}$ NMR $\left(50 \mathrm{MHz}, \mathrm{CDCl}_{3}\right): 13.4\left(\mathrm{CH}_{3}\right), 21.6\left(\mathrm{CH}_{3}\right), 32.9$ $\left(\mathrm{CH}_{3}\right), 53.9\left(\mathrm{CH}_{3}\right), 94.3(\mathrm{CH}), 101.7(\mathrm{CH}), 102.8(\mathrm{CH}), 109.8(\mathrm{CH})$, $110.5(\mathrm{CH}), 119.8(2)(\mathrm{CH}), 127.1(\mathrm{C}), 128.4(\mathrm{C}), 130.0(\mathrm{CH}), 135.1(\mathrm{C})$, 137.6 (C), 153.8 (C), 158.9 (C), 164.1 (C), 167.8 (C). HRMS $\left(\mathrm{C}_{20} \mathrm{H}_{20} \mathrm{~N}_{4} \mathrm{O}_{3} \mathrm{~S}\right)$ calcd $419.1148\left(\mathrm{M}+\mathrm{Na}^{+}\right)$, found 419.1160. HPLC: $\mathrm{C}_{8} \mathrm{t}_{\mathrm{R}}: 21.04 \mathrm{~min} . \mathrm{C}_{18} \mathrm{t}_{\mathrm{R}}: 22.60 \mathrm{~min}$.

\subsubsection{1. (2,6-dimethoxypyridin-4-yl)(naphthalen-2-yl)methanone}

(24). Prepared according to procedure 1: $31 \mathrm{mg}, 0.10 \mathrm{mmol}, 38 \%$ ). Amorphous powder. IR (film): 1662, $1562 \mathrm{~cm}^{-1} .{ }^{1} \mathrm{H}$ NMR $(200 \mathrm{MHz}$, $\left.\mathrm{CDCl}_{3}\right): 4.00(6 \mathrm{H}, \mathrm{s}), 6.62(2 \mathrm{H}, \mathrm{s}), 7.5-7.7(3 \mathrm{H}, \mathrm{m}), 7.9-8.0(3 \mathrm{H}, \mathrm{m})$, 8.29 (1H, bs). ${ }^{13} \mathrm{C}$ NMR (50 MHz, $\left.\mathrm{CDCl}_{3}\right): 53.9$ (2) $\left(\mathrm{CH}_{3}\right), 101.1$ (2) $(\mathrm{CH}), 125.1(\mathrm{CH}), 126.9(\mathrm{CH}), 127.8(\mathrm{CH}), 128.5(\mathrm{CH}), 128.8(\mathrm{CH})$, $129.6(\mathrm{CH}), 132.1(\mathrm{C}), 132.6(\mathrm{CH}), 133.3(\mathrm{C}), 135.6$ (C), $150.5(\mathrm{C})$, 163.4 (2) (C), 195.2 (C). HRMS $\left(\mathrm{C}_{18} \mathrm{H}_{15} \mathrm{NO}_{3}\right)$ calcd 294.1124 $\left(\mathrm{M}+\mathrm{H}^{+}\right)$, found 294.1138. HPLC: $\mathrm{C}_{18} \mathrm{t}_{\mathrm{R}}: 23.61 \mathrm{~min}$.

4.1.2.32. (2,6-dimethoxypyridin-4-yl)(1-methyl-1H-indol-5-yl)methanone (25). $3.9 \mathrm{~mL}$ of $n \mathrm{BuLi} 1.6 \mathrm{M}$ in hexane $(6.2 \mathrm{mmol})$ were added to a solution $685 \mathrm{mg}$ ( $3.3 \mathrm{mmol}$ ) of 5-bromo- $\mathrm{N}$-methyl- $1 \mathrm{H}$-indole in $50 \mathrm{~mL}$ of dry THF at $-40{ }^{\circ} \mathrm{C}$. After $1 \mathrm{~h}, 519 \mathrm{mg}$ (3.1 mmol) of 2,6dimethoxypyridin-4-carbaldehyde dissolved in $20 \mathrm{~mL}$ of dry THF were slowly added over $1 \mathrm{~h}$ and then allowed to reach room temperature. After $24 \mathrm{~h}$ the reaction was poured onto ethyl acetate and evaporated. The residue was dissolved in $20 \mathrm{~mL}$ of dry dichloromethane and $100 \mathrm{mg}(6.3 \mathrm{~mol})$ of $\mathrm{KMnO}_{4}$ and $2 \mathrm{mg}$ of tetrabutylammonium hydrogen sulfate were added and stirred for $24 \mathrm{~h}$ at room temperature. The crude was flash chromatographied using Hexane/ethyl acetate $1: 1$ to give $150 \mathrm{mg}(0.5 \mathrm{mmol}, 16 \%)$ of $(2,6$ dimethoxypyridin-4-yl)(1-methyl-1H-indol-5-yl)methanone

(25). Amorphous powder. IR (film): 1654, $1560 \mathrm{~cm}^{-1} .{ }^{1} \mathrm{H}$ NMR $(200 \mathrm{MHz}$, $\left.\mathrm{CDCl}_{3}\right)$ : $3.84(3 \mathrm{H}, \mathrm{s}), 3.97(6 \mathrm{H}, \mathrm{s}), 6.57(1 \mathrm{H}, \mathrm{m}), 6.58(2 \mathrm{H}, \mathrm{s}), 7.13(1 \mathrm{H}$, d, $\mathrm{J}=3.0$ ), 7.38 (1H, d, $J=9.0$ ), $7.86(1 \mathrm{H}, \mathrm{dd}, J=1.8, J=9.0), 8.13$ $(1 \mathrm{H}, \mathrm{d}, J=1.8) .{ }^{13} \mathrm{C}$ NMR (50 MHz, $\left.\mathrm{CDCl}_{3}\right): 33.1\left(\mathrm{CH}_{3}\right), 53.9(2)\left(\mathrm{CH}_{3}\right)$, $101.1(2)(\mathrm{CH}), 103.3(\mathrm{CH}), 109.4(\mathrm{CH}), 123.6(\mathrm{CH}), 125.9(\mathrm{CH}), 127.8$ (2) (C), 130.7 (CH), 139.4 (C), 152.1 (C), 163.3 (2) (C), 195.5 (C). HRMS $\left(\mathrm{C}_{17} \mathrm{H}_{16} \mathrm{~N}_{2} \mathrm{O}_{3}\right)$ calcd 297.1233 $\left(\mathrm{M}+\mathrm{H}^{+}\right)$, found 297.1241.

4.1.2.33. (2-methoxy-6-(methylsulfanyl)pyridin-4-yl)(naphthalen-2-yl) methanone (26). Prepared according to procedure 1: $329 \mathrm{mg}$ (1.1 mmol, 24\%). M.p. $76-77^{\circ} \mathrm{C}\left(\mathrm{Et}_{2} \mathrm{O}\right)$. IR (KBr): $1657,1589 \mathrm{~cm}^{-1}$. ${ }^{1} \mathrm{H}$ NMR $\left(200 \mathrm{MHz}, \mathrm{CDCl}_{3}\right): 2.61(3 \mathrm{H}, \mathrm{s}), 4.02(3 \mathrm{H}, \mathrm{s}), 6.70(1 \mathrm{H}, \mathrm{d}$, $J=1.1$ ), 7.08 (1H, d, $J=1.1$ ), 7.5-7.7 (3H, m), 7.8-8.0 (3H, m), 8.2 (1H, bs). ${ }^{13} \mathrm{C}$ NMR $\left(50 \mathrm{MHz}, \mathrm{CDCl}_{3}\right): 13.6\left(\mathrm{CH}_{3}\right), 53.9\left(\mathrm{CH}_{3}\right), 105.5$ $(\mathrm{CH}), 112.9(\mathrm{CH}), 125.2(\mathrm{CH}), 126.0(\mathrm{CH}), 127.9(\mathrm{CH}), 128.5(\mathrm{CH})$, $129.0(\mathrm{CH}), 129.7(\mathrm{CH}), 132.2(\mathrm{C}), 133.3(\mathrm{C}), 132.7(\mathrm{CH}), 136.7(\mathrm{C})$, 148.1 (C), 158.8 (C), 163.9 (C), 195.0 (C). HRMS $\left(\mathrm{C}_{18} \mathrm{H}_{15} \mathrm{NO}_{2} \mathrm{~S}\right)$ calcd 310.0896 $\left(\mathrm{M}+\mathrm{H}^{+}\right)$, found 310.0911. HPLC: $\mathrm{C}_{8} \mathrm{t}_{\mathrm{R}}$ : 21.79 min. $\mathrm{C}_{18} \mathrm{t}_{\mathrm{R}}$ : $23.58 \mathrm{~min}$.

4.1.2.34. (2-methoxy-6-(methylsulfanyl)pyridin-4-yl)(4-methoxyphenyl) methanone (27). Prepared according to procedure 1: $372 \mathrm{mg}$ (1.28 mmol, 51\%). M.p. $62{ }^{\circ} \mathrm{C}\left(\mathrm{Hex} / \mathrm{CH}_{2} \mathrm{Cl}_{2}\right)$. IR (KBr): 1659, $1545 \mathrm{~cm}^{-1}$. ${ }^{1} \mathrm{H}$ NMR (200 MHz, $\mathrm{CDCl}_{3}$ ): 2.59 (3H, s), $3.89(3 \mathrm{H}, \mathrm{s})$, $3.99(3 \mathrm{H}, \mathrm{s}), 6.61(1 \mathrm{H}, \mathrm{d}, J=1.1), 6.95(2 \mathrm{H}, \mathrm{d}, J=8.6), 6.97(1 \mathrm{H}, \mathrm{d}$, $J=1.1)$, $7.83(2 \mathrm{H}, \mathrm{d}, J=8.6) .{ }^{13} \mathrm{C}$ NMR $\left(50 \mathrm{MHz}, \mathrm{CDCl}_{3}\right): 13.4\left(\mathrm{CH}_{3}\right)$, $53.8\left(\mathrm{CH}_{3}\right), 55.6\left(\mathrm{CH}_{3}\right), 105.1(\mathrm{CH}), 112.6(\mathrm{CH}), 113.9(2)(\mathrm{CH}), 115.5$ (C), 128.6 (C), 132.6 (2) (CH), 148.5 (C), 158.5 (C), 163.9 (C), 193.5 (C). HRMS $\left(\mathrm{C}_{15} \mathrm{H}_{15} \mathrm{NO}_{3} \mathrm{~S}\right)$ : calcd $290.0845\left(\mathrm{M}+\mathrm{H}^{+}\right)$, found 290.0849 . HPLC: $\mathrm{C}_{18} \mathrm{t}_{\mathrm{R}}: 22.04 \mathrm{~min}$.

4.1.2.35. (2-methoxy-6-(methylsulfanyl)pyridin-4-yl)(1-methyl-1H-indol5-yl)methanone (28). Prepared according to procedure 1: $911 \mathrm{mg}$ (2.92 mmol, 49\%). M.p. $103-104{ }^{\circ} \mathrm{C}\left(\mathrm{Hex} / \mathrm{CH}_{2} \mathrm{Cl}_{2}\right)$. IR: 1647, $1545 \mathrm{~cm}^{-1}$. ${ }^{1} \mathrm{H}$ NMR $\left(200 \mathrm{MHz}, \mathrm{CDCl}_{3}\right): 2.49(3 \mathrm{H}, \mathrm{s}), 3.85(3 \mathrm{H}, \mathrm{s})$, $4.01(3 \mathrm{H}, \mathrm{s}), 6.59(1 \mathrm{H}, \mathrm{d}, J=2.9), 6.66(1 \mathrm{H}, \mathrm{d}, J=1.1), 7.02(1 \mathrm{H}, \mathrm{d}$, $J=1.1$ ), $7.13(1 \mathrm{H}, \mathrm{d}, J=2.9), 7.38(1 \mathrm{H}, \mathrm{d}, J=8.6), 7.81(1 \mathrm{H}, \mathrm{dd}$, $J=8.6, J=1.8), 8.10(1 \mathrm{H}, \mathrm{d}, J=1.8) .{ }^{13} \mathrm{C} \mathrm{NMR}\left(50 \mathrm{MHz}, \mathrm{CDCl}_{3}\right)$ : $13.5\left(\mathrm{CH}_{3}\right), 33.1\left(\mathrm{CH}_{3}\right), 53.9\left(\mathrm{CH}_{3}\right), 103.3(\mathrm{CH}), 105.3(\mathrm{CH}), 109.5$ (CH), $112.9(\mathrm{CH}), 123.4(\mathrm{CH}), 125.8(\mathrm{CH}), 127.7(\mathrm{C}), 128.8(\mathrm{C}), 130.9$ (CH), 139.4 (C), 149.6 (C), 158.3 (C), 163.7 (C), 195.2 (C). HRMS $\left(\mathrm{C}_{17} \mathrm{H}_{16} \mathrm{~N}_{2} \mathrm{O}_{2} \mathrm{~S}\right)$ calcd $313.1005\left(\mathrm{M}+\mathrm{H}^{+}\right)$, found 313.1013. HPLC: $\mathrm{C}_{18}$ $\mathrm{t}_{\mathrm{R}}: 20.85 \mathrm{~min}$.

\subsubsection{6. (4-(dimethylamino)phenyl)(2-methoxy-6-(methylsulfanyl)} pyridin-4-yl)methanone (29). Prepared according to procedure 1: $723 \mathrm{mg}(2.39 \mathrm{mmol}, 41 \%)$. Foam. IR (KBr): 1644, $1543 \mathrm{~cm}^{-1} .{ }^{1} \mathrm{H}$ NMR (200 MHz, $\left.\mathrm{CDCl}_{3}\right): 2.58(3 \mathrm{H}, \mathrm{s}), 3.09(6 \mathrm{H}, \mathrm{s}), 3.98(3 \mathrm{H}, \mathrm{s}), 6.59$ $(1 \mathrm{H}, \mathrm{d}, J=1.1), 6.67(2 \mathrm{H}, \mathrm{d}, J=9.1), 6.95(1 \mathrm{H}, \mathrm{d}, J=1.1), 7.77(2 \mathrm{H}$, $\mathrm{d}, J=9.1) .{ }^{13} \mathrm{C}$ NMR $\left(50 \mathrm{MHz}, \mathrm{CDCl}_{3}\right): 13.5\left(\mathrm{CH}_{3}\right), 40.1(2)\left(\mathrm{CH}_{3}\right), 53.8$ $\left(\mathrm{CH}_{3}\right), 104.9(\mathrm{CH}), 110.6(2)(\mathrm{CH}), 115.6(\mathrm{CH}), 123.2(\mathrm{C}), 132.7$ (2) (CH), 149.8 (C), 153.8 (C), 158.1 (C), 163.7 (C), 192.8 (C). HRMS $\left(\mathrm{C}_{16} \mathrm{H}_{18} \mathrm{~N}_{2} \mathrm{O}_{2} \mathrm{~S}\right)$ : calcd $303.1161\left(\mathrm{M}+\mathrm{H}^{+}\right)$, found 303.1154. HPLC: $\mathrm{C}_{8}$ $\mathrm{t}_{\mathrm{R}}: 19.04 \mathrm{~min}$.

\subsubsection{2,6-dimethoxy-4-(1-(4-methoxyphenyl)vinyl)pyridine}

(30). Prepared according to procedure 2: $4 \mathrm{mg}(0.015 \mathrm{mmol}, 0,8 \%)$. Oil. IR (film): $1609,1554 \mathrm{~cm}^{-1} .{ }^{1} \mathrm{H}$ NMR $\left(200 \mathrm{MHz}, \mathrm{CDCl}_{3}\right): 3.83(3 \mathrm{H}$, s), $3.91(6 \mathrm{H}, \mathrm{s}), 5.43(1 \mathrm{H}, \mathrm{s}), 5.45(1 \mathrm{H}, \mathrm{s}), 6.27(2 \mathrm{H}, \mathrm{s}), 6.86(2 \mathrm{H}, \mathrm{d}$, $J=8.6), 7.24(2 \mathrm{H}, \mathrm{d}, J=8.6) .{ }^{13} \mathrm{C}$ NMR $\left(50 \mathrm{MHz}, \mathrm{CDCl}_{3}\right): 53.6(2)$ $\left(\mathrm{CH}_{3}\right), 55.3\left(\mathrm{CH}_{3}\right), 100.7(2)(\mathrm{CH}), 113.6(2)(\mathrm{CH}), 114.6\left(\mathrm{CH}_{2}\right), 129.2$ (2) (CH), 132.5 (C), 147.6 (C), 159.2 (C), 159.5 (C), 163.2 (2) (C). HRMS $\left(\mathrm{C}_{16} \mathrm{H}_{17} \mathrm{NO}_{3}\right)$ : calcd $272.1281\left(\mathrm{M}+\mathrm{H}^{+}\right)$, found 272.1293 . HPLC: $\mathrm{C}_{18} \mathrm{t}_{\mathrm{R}}: 22.57 \mathrm{~min}$.

\subsubsection{2-methoxy-4-(1-(4-methoxyphenyl)vinyl)-6-(methylsulfanyl)} pyridine (31). Prepared according to procedure 2: $95 \mathrm{mg}(0.33 \mathrm{mmol}$, 49\%). Oil. IR (film): 1594, $1518 \mathrm{~cm}^{-1}$. ${ }^{1} \mathrm{H} \mathrm{NMR} \mathrm{(200} \mathrm{MHz}, \mathrm{CDCl}_{3}$ ): $2.56(3 \mathrm{H}, \mathrm{s}), 3.82(3 \mathrm{H}, \mathrm{s}), 3.96(3 \mathrm{H}, \mathrm{s}), 5.43(1 \mathrm{H}, \mathrm{d}, J=1.4), 5.47(1 \mathrm{H}$, $\mathrm{d}, J=1.4), 6.38(1 \mathrm{H}, \mathrm{d}, J=1.4), 6.74(1 \mathrm{H}, \mathrm{d}, J=1.4), 6.86(2 \mathrm{H}, \mathrm{d}$, $J=8.9), 7.23(2 \mathrm{H}, \mathrm{d}, J=8.9) .{ }^{13} \mathrm{C}$ NMR $\left(50 \mathrm{MHz}, \mathrm{CDCl}_{3}\right): 13.4\left(\mathrm{CH}_{3}\right)$, $53.6\left(\mathrm{CH}_{3}\right), 55.3\left(\mathrm{CH}_{3}\right), 105.0(\mathrm{CH}), 113.4(\mathrm{CH}), 113.7(2)(\mathrm{CH}), 115.0$ $\left(\mathrm{CH}_{2}\right), 129.3(2)(\mathrm{CH}), 132.3(\mathrm{C}), 147.3(\mathrm{C}), 152.5(\mathrm{C}), 157.1(\mathrm{C}), 159.6$ (C), 164.1 (C). HRMS $\left(\mathrm{C}_{16} \mathrm{H}_{17} \mathrm{NO}_{2} \mathrm{~S}\right)$ : calcd $288.1052\left(\mathrm{M}+\mathrm{H}^{+}\right)$, found 288.1068. HPLC: $\mathrm{C}_{18} \mathrm{t}_{\mathrm{R}}: 23.89 \mathrm{~min}$. 
4.1.2.39. 5-(1-(2-methoxy-6-(methylsulfanyl)pyridin-4-yl)vinyl)-1-

methyl-1H-indole (32). Prepared according to procedure 2: $30 \mathrm{mg}$ (0.10 mmol, 31\%). Oil. IR (film): 1593, $1543 \mathrm{~cm}^{-1} \cdot{ }^{1} \mathrm{H}$ NMR $\left(200 \mathrm{MHz}, \mathrm{CDCl}_{3}\right): 2.56(3 \mathrm{H}, \mathrm{s}), 3.80(3 \mathrm{H}, \mathrm{s}), 3.96(3 \mathrm{H}, \mathrm{s}), 5.48(1 \mathrm{H}$, d, $J=1.1), 5.54(1 \mathrm{H}, \mathrm{d}, J=1.1), 6.44(1 \mathrm{H}, \mathrm{d}, J=1.2), 6.47(1 \mathrm{H}, \mathrm{bd}$, $J=3.2), 6.79(1 \mathrm{H}, \mathrm{d}, J=1.2), 7.06(1 \mathrm{H}, \mathrm{d}, J=3.2), 7.18(1 \mathrm{H}, \mathrm{dd}$, $J=1.4, J=8.9), 7.28(1 \mathrm{H}, \mathrm{d}, \mathrm{J}=8.9), 7.55(1 \mathrm{H}, \mathrm{d}, J=1.4) .{ }^{13} \mathrm{C} \mathrm{NMR}$ $\left(50 \mathrm{MHz}, \mathrm{CDCl}_{3}\right): 13.4\left(\mathrm{CH}_{3}\right), 33.0\left(\mathrm{CH}_{3}\right), 53.6\left(\mathrm{CH}_{3}\right), 101.4(\mathrm{CH})$, $105.1(\mathrm{CH}), 109.0(\mathrm{CH}), 113.7(\mathrm{CH}), 114.9\left(\mathrm{CH}_{2}\right), 120.8(\mathrm{CH}), 122.1$ (CH), 128.0 (C), 136.6 (CH), 131.3 (C), 136.6 (C), 148.9 (C), 153.3 (C), 156.9 (C), 164.0 (C). HRMS $\left(\mathrm{C}_{18} \mathrm{H}_{18} \mathrm{~N}_{2} \mathrm{OS}\right)$ : calcd $311.1212\left(\mathrm{M}+\mathrm{H}^{+}\right)$, found 312.1219. HPLC: $\mathrm{C}_{8} \mathrm{t}_{\mathrm{R}}: 22.01 \mathrm{~min}$.

4.1.2.40. 4-(1-(2-methoxy-6-(methylsulfanyl)pyridin-4-yl)vinyl)- $N, N$ dimethylaniline (33). Prepared according to procedure 2: $90 \mathrm{mg}$ (0.30 mmol, 33\%). Oil. IR (film): 1592, $1532 \mathrm{~cm}^{-1}$. ${ }^{1} \mathrm{H}$ NMR $\left(200 \mathrm{MHz}, \mathrm{CDCl}_{3}\right): 2.56(3 \mathrm{H}, \mathrm{s}), 2.98(6 \mathrm{H}, \mathrm{s}), 3.95(3 \mathrm{H}, \mathrm{s}), 5.32(1 \mathrm{H}$, d, $J=1.1), 5.44(1 \mathrm{H}, \mathrm{d}, J=1.1), 6.40(1 \mathrm{H}, \mathrm{d}, J=1.1), 6.72(2 \mathrm{H}, \mathrm{d}$, $J=8.9), 6.76(1 \mathrm{H}, \mathrm{d}, J=1.1), 7.19(2 \mathrm{H}, \mathrm{d}, J=8.9) .{ }^{13} \mathrm{C} \mathrm{NMR}$ $\left(50 \mathrm{MHz}, \mathrm{CDCl}_{3}\right)$ : $13.5\left(\mathrm{CH}_{3}\right), 40.5(2)\left(\mathrm{CH}_{3}\right), 53.6\left(\mathrm{CH}_{3}\right), 105.1(\mathrm{CH})$, $110.6(\mathrm{CH}), 112.1(2)(\mathrm{CH}), 113.9\left(\mathrm{CH}_{2}\right), 128.8(2)(\mathrm{CH}), 132.8(\mathrm{C})$, 147.7 (C), 150.3 (C), 153.1 (C), 156.9 (C), 164.0 (C). HRMS $\left(\mathrm{C}_{17} \mathrm{H}_{20} \mathrm{~N}_{2} \mathrm{OS}\right)$ : calcd $301.1369\left(\mathrm{M}+\mathrm{H}^{+}\right)$, found 301.1351. HPLC: $\mathrm{C}_{8}$ $\mathrm{t}_{\mathrm{R}}: 22.3 \mathrm{~min}$.

4.1.2.41. Oximes of (2-methoxy-6-(methylsulfanyl)pyridin-4-yl)(4methoxyphenyl)methanone (34). Prepared according to procedure 3: $105 \mathrm{mg}(0.35 \mathrm{mmol}, 27 \%)$ of $34(E), 66 \mathrm{mg}(0.22 \mathrm{mmol}, 17 \%)$ of $34(Z)$, and $108 \mathrm{mg}(0.27 \mathrm{mmol}, 21 \%)$ of a $1: 1$ mixture of $\mathbf{3 4}(Z+E) .34(E)$ : M.p. $92-93{ }^{\circ} \mathrm{C}\left(\mathrm{Hex} / \mathrm{CH}_{2} \mathrm{Cl}_{2}\right)$. IR (KBr): $3272,3203,1598,1544 \mathrm{~cm}^{-1}$. ${ }^{1} \mathrm{H}$ NMR $\left(200 \mathrm{MHz}, \mathrm{CDCl}_{3}\right.$ ): 2.53 (3H, s), 3.85 (3H, s), 3.94 (3H, s), 6.46 $(1 \mathrm{H}, \mathrm{d}, J=1.1), 6.88(1 \mathrm{H}, \mathrm{d}, J=1.1), 6.96(2 \mathrm{H}, \mathrm{d}, J=8.9), 7.38(2 \mathrm{H}$, d, $J=8.9) .34(Z):{ }^{1} \mathrm{H} \mathrm{NMR} \mathrm{(200} \mathrm{MHz,} \mathrm{CDCl}_{3}$ ) $): 2.56(3 \mathrm{H}, \mathrm{s}), 3.80(3 \mathrm{H}$, s), $3.97(3 \mathrm{H}, \mathrm{s}), 6.42(1 \mathrm{H}, \mathrm{d}, J=1.1), 6.75(1 \mathrm{H}, \mathrm{d}, J=1.1), 6.84(2 \mathrm{H}$, d, $J=8.9$ ), $7.38(2 \mathrm{H}, \mathrm{d}, J=8.9) .{ }^{13} \mathrm{C}$ NMR $\left(50 \mathrm{MHz}, \mathrm{CDCl}_{3}, Z+E\right.$ Isomers): $13.4\left(\mathrm{CH}_{3}\right), 53.7\left(\mathrm{CH}_{3}\right), 55.4\left(\mathrm{CH}_{3}\right), 104.8(\mathrm{CH}), 105.5(\mathrm{CH})$, $112.4(\mathrm{CH}), 113.3(\mathrm{CH}), 113.7(2)(\mathrm{CH}), 114.0(2)(\mathrm{CH}), 123.3(\mathrm{C})$, 126.9 (C), 128.9 (2) (CH), 131.2 (2) (CH), 132.8 (C), 143.9 (C), 147.2 (C), 155.5 (C), 155.6 (C), 157.8 (C), 158.1 (C), 160.4 (C), 161.0 (C), 163.9 (C). HRMS $\left(\mathrm{C}_{15} \mathrm{H}_{16} \mathrm{~N}_{2} \mathrm{O}_{3} \mathrm{~S}\right)$ : calcd $305.0954\left(\mathrm{M}+\mathrm{H}^{+}\right)$, found 305.0962. HPLC: $\mathrm{C}_{18} \mathrm{t}_{\mathrm{R}}: 19.89 \mathrm{~min}, \mathrm{t}_{\mathrm{R}}: 20.25 \mathrm{~min}$.

4.1.2.42. Oximes of (2-methoxy-6-(methylsulfanyl)pyridin-4-yl)(1-methyl1 -indol-5-yl)methanone (35). Prepared according to procedure 3: $228 \mathrm{mg}(0.70 \mathrm{mmol}, 70 \%)$ of $\mathbf{3 5}(E)$ was isolated, but it isomerized to regenerate the original mixture of isomers (4:6). M.p. 155-157 ${ }^{\circ}$ (Hex/ $\mathrm{CH}_{2} \mathrm{Cl}_{2}$ ). IR: (KBr): $3272,3227,1589 \mathrm{~cm}^{-1} .{ }^{1} \mathrm{H} \mathrm{NMR}\left(200 \mathrm{MHz}, \mathrm{CDCl}_{3}\right.$, $E$ Isomer): $2.53(3 \mathrm{H}, \mathrm{s}), 3.83(3 \mathrm{H}, \mathrm{s}), 3.92(3 \mathrm{H}, \mathrm{s}), 6.48(1 \mathrm{H}, \mathrm{d}, J=1.1)$, 6.53 ( $1 \mathrm{H}, \mathrm{d}, J=3.2$ ), 6.93 ( $1 \mathrm{H}, \mathrm{d}, J=1.1$ ), 7.11 ( $1 \mathrm{H}, \mathrm{d}, J=3.2), 7.25$ $(1 \mathrm{H}, \mathrm{dd}, J=1.4, J=8.4), 7.39(1 \mathrm{H}, \mathrm{bd}, J=8.4), 7.66(1 \mathrm{H}, \mathrm{d}$, $J=1.4) .{ }^{13} \mathrm{C}$ NMR (50 MHz, $\mathrm{CDCl}_{3}, \mathrm{Z}+E$ Isomers): $13.4\left(\mathrm{CH}_{3}\right), 33.0$ $\left(\mathrm{CH}_{3}\right), 53.7\left(\mathrm{CH}_{3}\right), 101.9(\mathrm{CH}), 102.1(\mathrm{CH}), 104.9(\mathrm{CH}), 105.6(\mathrm{CH})$, $109.2(\mathrm{CH}), 109.5(\mathrm{CH}), 112.5(\mathrm{CH}), 113.5(\mathrm{CH}), 120.5(\mathrm{CH}), 121.5$ $(\mathrm{CH}), 122.5(\mathrm{CH}), 122.7(\mathrm{CH}), 125.8(\mathrm{C}), 128.2(\mathrm{C}), 129.8(\mathrm{CH}), 136.9$ (C), 137.4 (C), 144.8 (C), 147.9 (C), 157.0 (C), 157.2 (C), 157.6 (C), 157.9 (C), 163.9 (C). HRMS $\left(\mathrm{C}_{17} \mathrm{H}_{17} \mathrm{~N}_{3} \mathrm{O}_{2} \mathrm{~S}\right)$ : calcd 350.0933 $\left(\mathrm{M}+\mathrm{Na}^{+}\right)$, found 350.0953. HPLC: $\mathrm{C}_{18} \mathrm{t}_{\mathrm{R}}$ : $18.39 \mathrm{~min}, \mathrm{t}_{\mathrm{R}}: 18.90 \mathrm{~min}$.

4.1.2.43. Oximes of (4-(dimethylamino)phenyl)(2-methoxy-6(methylsulfanyl)pyridin-4-yl)methanone (36). Prepared according to procedure 3: $97 \mathrm{mg}(0.31 \mathrm{mmol}, 70 \%)$ of a 1:1 mixture of isomers $36(Z+E)$. M.p.: $142-144{ }^{\circ} \mathrm{C}\left(\mathrm{Hex} / \mathrm{CH}_{2} \mathrm{Cl}_{2}\right)$. IR (KBr): 3364, 3267, $1602 \mathrm{~cm}^{-1} .{ }^{1} \mathrm{H}$ NMR (200 MHz, $\mathrm{CDCl}_{3}, Z$ Isomer): $2.58(3 \mathrm{H}, \mathrm{s}), 2.99$ (6H, s), 3.98 (3H, s), 6.40 (1H, d, $J=1.1), 6.69$ (2H, d, $J=8.8), 6.91$ (1H, d, $J=1.1$ ), 7.39 (2H, d, $J=8.8$ ). ${ }^{1} \mathrm{H}$ NMR (200 MHz, $\mathrm{CDCl}_{3}, E$ Isomer): $2.55(3 \mathrm{H}, \mathrm{s}), 3.03(6 \mathrm{H}, \mathrm{s}), 3.94(3 \mathrm{H}, \mathrm{s}), 6.47(1 \mathrm{H}, \mathrm{d}, J=1.1)$,
6.83 (2H, d, $J=8.8$ ), 6.95 (1H, d, $J=1.1$ ), 7.35 (2H, d, $J=8.8$ ). ${ }^{13} \mathrm{C}$ NMR (50 MHz, $\mathrm{CDCl}_{3}, \mathrm{Z}+E$ Isomers): $13.5\left(\mathrm{CH}_{3}\right), 40.3(2)\left(\mathrm{CH}_{3}\right), 53.7$ $\left(\mathrm{CH}_{3}\right), 105.2(\mathrm{CH}), 111.3(2)(\mathrm{CH}), 111.8(2)(\mathrm{CH}), 112.9(\mathrm{CH}), 113.4$ $(\mathrm{CH}), 118.3(\mathrm{C}), 121.9(\mathrm{C}), 128.6(2)(\mathrm{CH}), 131.3(2)(\mathrm{CH}), 144.6(\mathrm{C})$, 148.0 (C), 151.0 (C), 155.8 (C), 157.6 (C), 163.8 (C). HRMS $\left(\mathrm{C}_{16} \mathrm{H}_{19} \mathrm{~N}_{3} \mathrm{O}_{2} \mathrm{~S}\right)$ : calcd $318.1270\left(\mathrm{M}+\mathrm{H}^{+}\right)$, found 318.1283. HPLC: $\mathrm{C}_{8} \mathrm{t}_{\mathrm{R}}: 17.85 \mathrm{~min}, \mathrm{t}_{\mathrm{R}}: 18.20 \mathrm{~min}$.

\subsubsection{2-methoxy-4-(1-(4-methoxyphenyl)ethyl)-6-(methylsulfanyl)} pyridine (37). A spatula of active $\mathrm{Pd} / \mathrm{C}$ was added to a solution of 31 (46 mg, $0.16 \mathrm{mmol}$ ) in $5-10 \mathrm{~mL}$ of ethyl acetate/EtOH under $\mathrm{H}_{2}$ atmosphere. After $24 \mathrm{~h}$ stirring at room temperature, the suspension was filtered through Celite and the solvent was evaporated. The product was purified by flash chromatography obtaining $8 \mathrm{mg}(0.03 \mathrm{mmol}$, $17 \%$ ) of compound 37. Foam. IR (film): $1591 \mathrm{~cm}^{-1} \cdot{ }^{1} \mathrm{H}$ NMR (200 MHz, $\mathrm{CDCl}_{3}$ ): 1.55 (3H, d, $\left.J=6.7\right), 2.53(3 \mathrm{H}, \mathrm{s}), 3.79(3 \mathrm{H}, \mathrm{s})$, $3.91(3 \mathrm{H}, \mathrm{s}), 3.95(1 \mathrm{H}, \mathrm{q}, J=6.7), 6.26(1 \mathrm{H}, \mathrm{s}), 6.61(1 \mathrm{H}, \mathrm{s}), 6.83(2 \mathrm{H}$, $\mathrm{d}, J=8.3), 7.11(2 \mathrm{H}, \mathrm{d}, J=8.3) .{ }^{13} \mathrm{C}$ NMR $\left(50 \mathrm{MHz}, \mathrm{CDCl}_{3}\right): 13.2$ $\left(\mathrm{CH}_{3}\right), 21.1\left(\mathrm{CH}_{3}\right), 43.3(\mathrm{CH}), 53.3\left(\mathrm{CH}_{3}\right), 55.2\left(\mathrm{CH}_{3}\right), 104.3(\mathrm{CH})$, $113.4(\mathrm{CH}), 113.8(2)(\mathrm{CH}), 114.1(\mathrm{C}), 128.4(2)(\mathrm{CH}), 136.5(\mathrm{C}), 156.7$ (C), 158.6 (C), 164.0 (C). HRMS $\left(\mathrm{C}_{16} \mathrm{H}_{19} \mathrm{NO}_{2} \mathrm{~S}\right)$ : calcd 290.1209 $\left(\mathrm{M}+\mathrm{H}^{+}\right)$, found 290.1205. HPLC: $\mathrm{C}_{8} \mathrm{t}_{\mathrm{R}}: 20.72 \mathrm{~min}$.

4.1.2.45. (4-methoxy-3-nitrophenyl)(2-methoxy-6-(methylsulfanyl) pyridin-4-yl)methanone (38). $0.43 \mathrm{~mL}$ of a $1: 5 \quad\left(\mathrm{HNO}_{3} /\right.$ water) $(1.13 \mathrm{mmol})$ solution was added to $0.33 \mathrm{~g}(1.13 \mathrm{mmol})$ of compound 27 in $\mathrm{H}_{2} \mathrm{SO}_{4}(5.10 \mathrm{~mL})$ at $0{ }^{\circ} \mathrm{C}$. Five minutes later, it was poured onto a suspension of dichloromethane and anhydrous sodium carbonate. Then, it was filtered and evaporated to dryness under vacuum. The organic phase was purified by flash chromatography, obtaining $89 \mathrm{mg}$ (0.27 mmol, 24\%) of compound 38. Foam. IR (film): 1667, 1611, $1540 \mathrm{~cm}^{-1} .{ }^{1} \mathrm{H}$ NMR $\left(200 \mathrm{MHz}, \mathrm{CDCl}_{3}\right): 2.58(3 \mathrm{H}, \mathrm{s}), 3.99$ (3H, s), 4.05 $(3 \mathrm{H}, \mathrm{s}), 6.56(1 \mathrm{H}, \mathrm{d}, J=1.1), 6.95(1 \mathrm{H}, \mathrm{d}, J=1.1), 7.18(1 \mathrm{H}, \mathrm{bd}$, $J=8.9), 8.03(1 \mathrm{H}, \mathrm{dd}, J=2.2, J=8.9), 8.30(1 \mathrm{H}, \mathrm{d}, J=2.2) .{ }^{13} \mathrm{C}$ NMR (50 MHz, $\left.\mathrm{CDCl}_{3}\right): 13.5\left(\mathrm{CH}_{3}\right), 54.0\left(\mathrm{CH}_{3}\right), 57.1\left(\mathrm{CH}_{3}\right), 104.9(\mathrm{CH})$, $112.3(\mathrm{CH}), 113.4(\mathrm{CH}), 127.9(\mathrm{CH}), 128.3(\mathrm{C}), 135.9(\mathrm{CH}), 139.4(\mathrm{C})$, 146.8 (C), 156.6 (C), 159.4 (C), 163.9 (C), 191.8 (C). HRMS $\left(\mathrm{C}_{15} \mathrm{H}_{14} \mathrm{~N}_{2} \mathrm{O}_{5} \mathrm{~S}\right)$ : calcd $335.0696\left(\mathrm{M}+\mathrm{H}^{+}\right)$, found 335.0716. HPLC: $\mathrm{C}_{18} \mathrm{t}_{\mathrm{R}}: 20.92 \mathrm{~min}$.

\subsubsection{6. (3-amino-4-methoxyphenyl)(2-methoxy-6-(methylsulfanyl)} pyridin-4-yl)methanone (39). Fe (65 mg, $1.17 \mathrm{mmol})$ was added onto a solution of compound 38 (50 mg, $0.15 \mathrm{mmol}$ ) in $5 \mathrm{~mL}$ of ethanol, water and acetic acid in a 2:2:1 proportion and a drop of $37 \% \mathrm{HCl}$ and was stirred at $100{ }^{\circ} \mathrm{C}$ for half an hour. The suspension was filtered through Celite and the solvent was evaporated in vacuum. The crude was redissolved in dichloromethane and washed with a $5 \% \mathrm{NaHCO}_{3}$ solution. The organic phase was washed with brine, dried over anhydrous sodium sulfate, filtered and evaporated. The product was purified by flash chromatography, to obtain $11 \mathrm{mg}$ ( $0.04 \mathrm{mmol}, 24 \%)$ of compound 39. Foam. IR (film): 3368, 1654, $1543 \mathrm{~cm}^{-1}$. ${ }^{1} \mathrm{H}$ NMR $(200 \mathrm{MHz}$, $\mathrm{CDCl}_{3}$ ): 2.58 (3H, s), $3.96(3 \mathrm{H}, \mathrm{s}), 3.99(3 \mathrm{H}, \mathrm{s}), 6.60(1 \mathrm{H}, \mathrm{d}, J=1.2$ ), 6.86 (1H, bd, $J=8.8), 6.97(1 \mathrm{H}, \mathrm{d}, J=1.2), 7.36(1 \mathrm{H}, \mathrm{dd}, J=2.2$, $J=8.8), 7.51(1 \mathrm{H}, \mathrm{d}, J=2.2) .{ }^{13} \mathrm{C}$ NMR $\left(50 \mathrm{MHz}, \mathrm{CDCl}_{3}\right): 13.3\left(\mathrm{CH}_{3}\right)$, $53.8\left(\mathrm{CH}_{3}\right), 55.8\left(\mathrm{CH}_{3}\right), 105.1(\mathrm{CH}), 109.4(\mathrm{CH}), 112.6(\mathrm{CH}), 116.8$ (CH), 124.0 (C), $124.4(\mathrm{CH}), 129.0$ (C), 148.6 (C), 152.4 (C), 158.3 (C), 163.7 (C), 193.7 (C). HRMS $\left(\mathrm{C}_{15} \mathrm{H}_{16} \mathrm{~N}_{2} \mathrm{O}_{3} \mathrm{~S}\right)$ : calcd $305.0954\left(\mathrm{M}+\mathrm{H}^{+}\right)$, found 305.0961. HPLC: $\mathrm{C}_{8} \mathrm{t}_{\mathrm{R}}: 14.81 \mathrm{~min}$.

4.1.2.47. 5-(2-methoxy-6-(methylsulfanyl)isonicotinoyl)-1-methyl-1Hindole-3-carbaldehyde (40). Prepared according to procedure 6: $145 \mathrm{mg}$ (0.42 mmol, 51\%). Foam. IR: (film): 1654, 1614, $1591 \mathrm{~cm}^{-1} .{ }^{1} \mathrm{H}$ NMR (200 MHz, $\left.\mathrm{CDCl}_{3}\right): 2.59(3 \mathrm{H}, \mathrm{s}), 3.93(3 \mathrm{H}, \mathrm{s}), 4.00(3 \mathrm{H}, \mathrm{s}), 6.64(1 \mathrm{H}, \mathrm{d}$, $J=1.1), 7.03(1 \mathrm{H}, \mathrm{d}, J=1.1), 7.44(1 \mathrm{H}, \mathrm{bd}, J=8.9), 7.78(1 \mathrm{H}, \mathrm{s})$, $7.90(1 \mathrm{H}, \mathrm{dd}, J=1.4, J=8.9), 8.69(1 \mathrm{H}, \mathrm{d}, J=1.4), 9.99(1 \mathrm{H}, \mathrm{s}) .{ }^{13} \mathrm{C}$ $\operatorname{NMR}\left(50 \mathrm{MHz}, \mathrm{CDCl}_{3}\right)$ : $13.6\left(\mathrm{CH}_{3}\right), 34.0\left(\mathrm{CH}_{3}\right), 53.9\left(\mathrm{CH}_{3}\right), 105.5(\mathrm{CH})$, 
$110.3(\mathrm{CH}), 112.8(\mathrm{CH}), 119.0(\mathrm{C}), 124.6$ (C), $125.8(2)(\mathrm{CH}), 131.1(\mathrm{C})$, 140.4 (C), 140.7 (CH), 148.5 (C), 158.6 (C), 160.8 (C), 184.3 (CHO), 195.2 (C). HRMS $\left(\mathrm{C}_{18} \mathrm{H}_{16} \mathrm{~N}_{2} \mathrm{O}_{3} \mathrm{~S}\right)$ : calcd $341.0954\left(\mathrm{M}+\mathrm{H}^{+}\right)$, found 341.0959. HPLC: $\mathrm{C}_{8} \mathrm{t}_{\mathrm{R}}: 15.85 \mathrm{~min}$.

4.1.2.48. (5-((hydroxyimino)(2-methoxy-6-(methylsulfanyl)pyridin-4-yl) methyl)-1-methyl-1H-indole-3-carbonitrile (42) and 5-(2-methoxy-6(methylsulfanyl)isonicotinoyl)-1-methyl-1H-indole-3-carbonitrile

(41). Prepared according to procedure 7: $10 \mathrm{mg}(0.029 \mathrm{mmol}, 15 \%)$ of 41, $5 \mathrm{mg}(0.014 \mathrm{mmol}, 7 \%)$ of $42 E, 5 \mathrm{mg}(0.014 \mathrm{mmol}, 7 \%)$ of $42 Z$, and $9 \mathrm{mg}(0.026,13 \%)$ of a $1: 1$ mixture of oximes $42 Z+E$. Phenstatin 41 was recovered after dissolving oximes 42 in $\mathrm{CDCl}_{3}$.

41: Foam. IR (film): 1661, 2221, 1609, $1542 \mathrm{~cm}^{-1} \cdot{ }^{1} \mathrm{H}$ NMR $\left(200 \mathrm{MHz}, \mathrm{CDCl}_{3}\right): 2.55$ (3H, s), 3.87 (3H, s), 3.95 (3H, s), $6.56(1 \mathrm{H}, \mathrm{d}$, $J=1.2), 6.96$ (1H, d, $J=1.2), 7.43$ (1H, d, $J=8.4$ ), $7.62(1 \mathrm{H}, \mathrm{s}), 7.86$ $(1 \mathrm{H}, \mathrm{dd}, J=1.6, J=8.4), 8.11(1 \mathrm{H}, \mathrm{d}, J=1.6) .{ }^{13} \mathrm{C} \mathrm{NMR}(50 \mathrm{MHz}$, $\left.\mathrm{CDCl}_{3}\right): 13.4\left(\mathrm{CH}_{3}\right), 33.9\left(\mathrm{CH}_{3}\right), 53.8\left(\mathrm{CH}_{3}\right), 105.2(\mathrm{CH}), 110.6(\mathrm{CH})$, $112.6(\mathrm{CH}), 114.7(\mathrm{C}), 115.6(\mathrm{C}), 123.8(\mathrm{CH}), 125.5(\mathrm{CH}), 127.0(\mathrm{C})$, 130.5 (C), 137.3 (CH), 148.2 (C), 158.8 (C), 163.6 (C), 194.8 (C). HRMS $\left(\mathrm{C}_{18} \mathrm{H}_{15} \mathrm{~N}_{3} \mathrm{O}_{2} \mathrm{~S}\right)$ : calcd $338.0958\left(\mathrm{M}+\mathrm{H}^{+}\right)$, found 338.0943. HPLC: $\mathrm{C}_{8}$ $\mathrm{t}_{\mathrm{R}}: 17.89 \mathrm{~min}$.

42E: Amorphous solid. IR (film): 3309, 2221, $1590 \mathrm{~cm}^{-1} .{ }^{1} \mathrm{H}$ NMR (200 MHz, $\mathrm{CDCl}_{3}$ ): 2.50 (3H, s), 3.84 (3H, s), 3.87 (3H, s), 6.33 (1H, d, $J=1.2), 6.86(1 \mathrm{H}, \mathrm{d}, J=1.2), 7.26(1 \mathrm{H}, \mathrm{bd}, J=8.8), 7.41(1 \mathrm{H}, \mathrm{d}$, $J=8.8), 7.57(1 \mathrm{H}, \mathrm{s}), 7.72(1 \mathrm{H}, \mathrm{bs})$. HRMS $\left(\mathrm{C}_{18} \mathrm{H}_{16} \mathrm{~N}_{4} \mathrm{O}_{2} \mathrm{~S}\right)$ : calcd 353.1067 $\left(\mathrm{M}+\mathrm{H}^{+}\right)$, found 353.1069. HPLC: $\mathrm{C}_{8} \mathrm{t}_{\mathrm{R}}: 15.80 \mathrm{~min}$

42Z: Amorphous solid. IR (film): 3309, 2221, $1591 \mathrm{~cm}^{-1} \cdot{ }^{1} \mathrm{H} \mathrm{NMR}$ $\left(200 \mathrm{MHz}_{\mathrm{CDCl}}\right.$ ): 2.54 (3H, s), $3.80(3 \mathrm{H}, \mathrm{s}), 3.95(3 \mathrm{H}, \mathrm{s}), 6.34(1 \mathrm{H}, \mathrm{d}$, $J=1.2), 6.68(1 \mathrm{H}, \mathrm{s}, J=1.2), 7.30(1 \mathrm{H}, \mathrm{d}, J=8.8), 7.52(1 \mathrm{H}, \mathrm{bs})$, $7.55(1 \mathrm{H}$, bd, $J=8.8), 7.65(1 \mathrm{H}, \mathrm{s})$. HRMS $\left(\mathrm{C}_{18} \mathrm{H}_{16} \mathrm{~N}_{4} \mathrm{O}_{2} \mathrm{~S}\right)$ : calcd 353.1067 $\left(\mathrm{M}+\mathrm{H}^{+}\right)$, found 353.1071. HPLC: $\mathrm{C}_{8} \mathrm{t}_{\mathrm{R}}$ : $16.72 \mathrm{~min}$.

4.1.2.49. 5-(1-(2-methoxy-6-(methylsulfanyl)pyridin-4-yl)vinyl)-1methyl-1H-indole-3-carbaldehyde (43). Prepared according to procedure 6: $52 \mathrm{mg}$ (0.15 mmol, 59\%). Oil. IR: (film): $1658,1589 \mathrm{~cm}^{-1} .{ }^{1} \mathrm{H}$ NMR $\left(200 \mathrm{M}, \mathrm{CDCl}_{3}\right): 2.53(3 \mathrm{H}, \mathrm{s}), 3.85(3 \mathrm{H}, \mathrm{s}), 3.94(3 \mathrm{H}, \mathrm{s}), 5.56(1 \mathrm{H}, \mathrm{s})$, $5.57(1 \mathrm{H}, \mathrm{s}), 6.36(1 \mathrm{H}, \mathrm{d}, J=1.1), 6.73(1 \mathrm{H}, \mathrm{d}, J=1.1), 7.20(1 \mathrm{H}, \mathrm{dd}$, $J=1.4, J=8.9), 7.26(1 \mathrm{H}, \mathrm{bd}, J=8.9), 7.66(1 \mathrm{H}, \mathrm{s}), 8.28(1 \mathrm{H}, \mathrm{d}$, $J=1.4), 9.94(1 \mathrm{H}, \mathrm{s}) .{ }^{13} \mathrm{C} \mathrm{NMR}\left(50 \mathrm{MHz}, \mathrm{CDCl}_{3}\right): 13.4\left(\mathrm{CH}_{3}\right), 33.8$ $\left(\mathrm{CH}_{3}\right), 53.5\left(\mathrm{CH}_{3}\right), 104.9(\mathrm{CH}), 109.7(\mathrm{CH}), 113.3(\mathrm{CH}), 116.2\left(\mathrm{CH}_{2}\right)$, $118.2(\mathrm{C}), 121.7(\mathrm{CH}), 124.7(\mathrm{CH}), 125.3(\mathrm{C}), 135.3(\mathrm{C}), 137.7(\mathrm{C})$, 139.9 (CH), 148.2 (C), 152.6 (C), 157.1 (C), 164.0 (C), 184.4 (CHO). HRMS $\left(\mathrm{C}_{19} \mathrm{H}_{17} \mathrm{~N}_{2} \mathrm{O}_{2} \mathrm{~S}\right)$ : calcd 361,0981 $\left(\mathrm{M}+\mathrm{H}^{+}\right)$, found 361.0992. HPLC: $\mathrm{C}_{8} \mathrm{t}_{\mathrm{R}}: 19.29 \mathrm{~min}$.

4.1.2.50. 5-(1-(2-methoxy-6-(methylsulfanyl)pyridin-4-yl)vinyl)-1-

methyl-1H-indole-3-carboxylic acid (44). $172 \mu \mathrm{L}(0.325 \mathrm{mmol})$ of $20 \%$ phosgene in toluene were added onto $101 \mathrm{mg}(0.325 \mathrm{mmol})$ of compound 32 in $20 \mathrm{~mL}$ of dichloromethane. The reaction was monitored by ${ }^{1} \mathrm{H}$ NMR, and, after $24 \mathrm{~h}, 172 \mu \mathrm{L}$ ( $0.325 \mathrm{mmol}$ ) of $20 \%$ phosgene in toluene were added. After $72 \mathrm{~h}$, the reaction was poured onto ice water. The solution was basified with $5 \% \mathrm{NaOH}$ and extracted with ethyl acetate (organic phase A). The aqueous phase was acidified with $2 \mathrm{~N} \mathrm{HCl}$, and extracted with dichloromethane (organic phase B). The organic phase $\mathrm{B}$ was washed with brine, dried over anhydrous $\mathrm{Na}_{2} \mathrm{SO}_{4}$, filtered and evaporated to dryness to obtain $31 \mathrm{mg}$ (0.087 mmol, 27\%) of compound 44. Amorphous solid. IR (film): 1660, $1591 \mathrm{~cm}^{-1} .{ }^{1} \mathrm{H}$ NMR $\left(200 \mathrm{MHz}, \mathrm{CDCl}_{3}\right): 2.55(3 \mathrm{H}, \mathrm{s}), 3.86(3 \mathrm{H}$, s), $3.95(3 \mathrm{H}, \mathrm{s}), 5.59(2 \mathrm{H}, \mathrm{s}), 6.40(1 \mathrm{H}, \mathrm{s}), 6.76(1 \mathrm{H}, \mathrm{s}), 7.15(1 \mathrm{H}, \mathrm{d}$, $J=8.9), 7.30$ (1H, bd, $J=8.9), 7.90(1 \mathrm{H}, \mathrm{bs}), 8.22(1 \mathrm{H}, \mathrm{s}) .{ }^{13} \mathrm{C} \mathrm{NMR}$ $\left(50 \mathrm{MHz}, \mathrm{CDCl}_{3}\right): 13.5\left(\mathrm{CH}_{3}\right), 33.7\left(\mathrm{CH}_{3}\right), 53.9\left(\mathrm{CH}_{3}\right), 104.9(\mathrm{CH})$, $106.6(\mathrm{C}), 109.7(\mathrm{CH}), 113.4(\mathrm{CH}), 116.5\left(\mathrm{CH}_{2}\right), 121.5(\mathrm{CH}), 123.8$ (CH), 126.9 (C), 134.6 (C), 137.2 (CH), $148.5(\mathrm{C}), 152.7$ (C), $157.1(\mathrm{C})$, 164.0 (C), 170.2 (C). HRMS $\left(\mathrm{C}_{19} \mathrm{H}_{18} \mathrm{~N}_{2} \mathrm{O}_{3} \mathrm{~S}\right)$ : calcd $355.1110\left(\mathrm{M}+\mathrm{H}^{+}\right)$, found 355.1113. HPLC: $\mathrm{C}_{8} \mathrm{t}_{\mathrm{R}}: 20.28 \mathrm{~min}$.
4.1.2.51. (2-methoxy-6-(methylsulfinyl)pyridin-4-yl)(naphthalen-2-yl) methanone (45) and (2-methoxy-6-(methylsulfonyl)pyridin-4-yl) (naphthalen-2-yl)methanone (46). $97 \mathrm{mg}(0.57 \mathrm{mmol})$ of $m$ CPBA was added onto a solution of $175 \mathrm{mg}(0.57 \mathrm{mmol})$ of compound 26 in $10 \mathrm{~mL}$ of dichloromethane and stirred for $24 \mathrm{~h}$ at $0{ }^{\circ} \mathrm{C}$. Sodium bisulfite was added and the solution was extracted with ethyl acetate, washed with water and a $5 \%$ solution of sodium bicarbonate. The organic layers were dried over $\mathrm{Na}_{2} \mathrm{SO}_{4}$, filtered, evaporated and purified by flash chromatography to obtain $49 \mathrm{mg}(0.15 \mathrm{mmol}, 26.3 \%)$ of compound 45 and $19 \mathrm{mg}$ (0.06 mmol, 10.5\%) of compound 46.

45: Foam. IR (film): 1665, 1600, $1543 \mathrm{~cm}^{-1} .{ }^{1} \mathrm{H}$ NMR $(200 \mathrm{MHz}$, $\left.\mathrm{CDCl}_{3}\right): 2.91(3 \mathrm{H}, \mathrm{s}), 4.02(3 \mathrm{H}, \mathrm{s}), 7.12(1 \mathrm{H}, \mathrm{d}, J=1.4), 7.5-7.7(3 \mathrm{H}$, m), $7.87(1 \mathrm{H}, \mathrm{d}, J=1.4), 7.9-8.0(3 \mathrm{H}, \mathrm{m}), 8.25(1 \mathrm{H}, \mathrm{bs}) .{ }^{13} \mathrm{C} \mathrm{NMR}$ $\left(50 \mathrm{MHz}, \mathrm{CDCl}_{3}\right): 40.8\left(\mathrm{CH}_{3}\right), 54.5\left(\mathrm{CH}_{3}\right), 112.4(\mathrm{CH}), 112.6(\mathrm{CH})$, $124.9(\mathrm{CH}), 127.1(\mathrm{CH}), 127.9(\mathrm{CH}), 129.1(\mathrm{CH}), 129.2(\mathrm{CH}), 129.8$ (CH), 132.2 (2) (C), 132.7 (CH), 135.8 (C), 149.6 (C), 163.9 (C), 164.3 (C), 193.9 (C). HRMS $\left(\mathrm{C}_{18} \mathrm{H}_{15} \mathrm{NO}_{3} \mathrm{~S}\right)$ : calcd $326.0846\left(\mathrm{M}+\mathrm{H}^{+}\right)$, found 326.0849. HPLC: $\mathrm{C}_{18} \mathrm{t}_{\mathrm{R}}: 16.39 \mathrm{~min}$.

46: Foam. IR (film): 1665, 1603, $1543 \mathrm{~cm}^{-1} .{ }^{1} \mathrm{H}$ NMR $(200 \mathrm{MHz}$, $\left.\mathrm{CDCl}_{3}\right): 3.26(3 \mathrm{H}, \mathrm{s}), 4.09(3 \mathrm{H}, \mathrm{s}), 7.29(1 \mathrm{H}, \mathrm{d}, J=1.2), 7.5-7.7(3 \mathrm{H}$, $\mathrm{m}), 7.98(1 \mathrm{H}, \mathrm{d}, J=1.2), 7.9-8.0(3 \mathrm{H}, \mathrm{m}), 8.22(1 \mathrm{H}, \mathrm{bs}) .{ }^{13} \mathrm{C} \mathrm{NMR}$ $\left(50 \mathrm{MHz}, \mathrm{CDCl}_{3}\right): 39.8\left(\mathrm{CH}_{3}\right), 54.8\left(\mathrm{CH}_{3}\right), 113.5(\mathrm{CH}), 115.9(\mathrm{CH})$, $124.7(\mathrm{CH}), 127.3(\mathrm{CH}), 127.9(\mathrm{CH}), 129.1(\mathrm{CH}), 129.3(\mathrm{CH}), 129.8$ (CH), 132.1 (C), $132.4(\mathrm{C}), 132.8(\mathrm{CH}), 135.8(\mathrm{C}), 149.7$ (C), $155.6(\mathrm{C})$, 164.5 (C), 193.1 (C). HRMS $\left(\mathrm{C}_{18} \mathrm{H}_{15} \mathrm{NO}_{4} \mathrm{~S}\right)$ : calcd $342.3884\left(\mathrm{M}+\mathrm{H}^{+}\right)$, found 342.3893. HPLC: $\mathrm{C}_{18} \mathrm{t}_{\mathrm{R}}: 16.81 \mathrm{~min}$.

4.1.2.52. (2-methoxy-6-(methylsulfinyl)pyridin-4-yl)(1-methyl-1H-indol5 -yl)methanone (47). $180 \mathrm{mg}$ (1.04 mmol) of $m$ CPBA was added onto a solution of $325 \mathrm{mg}(1.04 \mathrm{mmol})$ of compound 28 in $10 \mathrm{~mL}$ of dichloromethane and stirred for $24 \mathrm{~h}$ at $0{ }^{\circ} \mathrm{C}$. Sodium bisulfite was added and the solution was extracted in ethyl acetate, washed with water and a solution of $5 \%$ sodium bicarbonate. The organic layers were dried over $\mathrm{Na}_{2} \mathrm{SO}_{4}$, filtered, evaporated and purified by flash chromatography to obtain $48 \mathrm{mg}(0.146 \mathrm{mmol}, 14 \%)$ of compound 47. Foam. IR (film): 1656, 1602, $1543 \mathrm{~cm}^{-1} .{ }^{1} \mathrm{H}$ NMR (200 $\left.\mathrm{MHz}, \mathrm{CDCl}_{3}\right)$ : $2.90(3 \mathrm{H}, \mathrm{s}), 3.85(3 \mathrm{H}, \mathrm{s}), 4.00(3 \mathrm{H}, \mathrm{s}), 6.59(1 \mathrm{H}, \mathrm{d}, J=3.0), 7.07(1 \mathrm{H}$, d, $J=1.2), 7.15(1 \mathrm{H}, \mathrm{d}, J=3.0), 7.39(1 \mathrm{H}, \mathrm{bd}, J=8.6), 7.82(1 \mathrm{H}, \mathrm{dd}$, $J=1.8, J=8.6), 7.82(1 \mathrm{H}, \mathrm{d}, J=1.2), 8.08(1 \mathrm{H}, \mathrm{d}, J=1.8) .{ }^{13} \mathrm{C} \mathrm{NMR}$ (50 MHz, $\left.\mathrm{CDCl}_{3}\right): 33.2\left(\mathrm{CH}_{3}\right), 40.8\left(\mathrm{CH}_{3}\right), 54.4\left(\mathrm{CH}_{3}\right), 103.5(\mathrm{CH})$, $109.7(\mathrm{CH}), 111.9(\mathrm{CH}), 112.4(\mathrm{CH}), 123.5(\mathrm{CH}), 125.9(\mathrm{CH}), 127.2(\mathrm{C})$, 127.9 (C), 131.0 (CH), 139.6 (C), 151.2 (C), 163.3 (C), 164.2 (C), 194.5 (C). HRMS $\left(\mathrm{C}_{17} \mathrm{H}_{16} \mathrm{~N}_{2} \mathrm{O}_{3} \mathrm{~S}\right)$ : calcd $329.0954\left(\mathrm{M}+\mathrm{H}^{+}\right)$, found 329.0968 . HPLC: $\mathrm{C}_{18} \mathrm{t}_{\mathrm{R}}$ : $15.62 \mathrm{~min}$.

4.1.2.53. (2-methoxy-6-(methylsulfonyl)pyridin-4-yl)(1-methyl-1H-indol5 -yl)methanone (48). $185 \mathrm{mg}$ (1.07 mmol) of mCPBA was added onto a solution of $224 \mathrm{mg}(0.72 \mathrm{mmol})$ of compound 47 in $10 \mathrm{~mL}$ of dichloromethane and stirred for $24 \mathrm{~h}$ at $0{ }^{\circ} \mathrm{C}$. Sodium bisulfite was added and the solution was extracted in ethyl acetate, washed with water and a solution of $5 \%$ sodium bicarbonate. The organic layers were dried over $\mathrm{Na}_{2} \mathrm{SO}_{4}$, filtered, evaporated and purified by flash chromatography to obtain $8 \mathrm{mg}(0.02 \mathrm{mmol}, 3.2 \%)$ of compound 48 . Foam. IR (film): 1658, 1604, $1543 \mathrm{~cm}^{-1} .{ }^{1} \mathrm{H}$ NMR (200 MHz, $\mathrm{CDCl}_{3}$ ): $3.24(3 \mathrm{H}, \mathrm{s}), 3.85(3 \mathrm{H}, \mathrm{s}), 4.07(3 \mathrm{H}, \mathrm{s}), 6.60(1 \mathrm{H}, \mathrm{d}, J=3.2), 7.16(1 \mathrm{H}$, d, $J=3.2), 7.25(1 \mathrm{H}, \mathrm{d}, J=1.1), 7.42(1 \mathrm{H}, \mathrm{d}, J=8.6), 7.79(1 \mathrm{H}, \mathrm{dd}$, $J=1.8, J=8.6), 7.93(1 \mathrm{H}, \mathrm{d}, J=1.1), 8.05(1 \mathrm{H}, \mathrm{d}, J=1.8) .{ }^{13} \mathrm{C} \mathrm{NMR}$ (50 MHz, $\left.\mathrm{CDCl}_{3}\right): 33.1\left(\mathrm{CH}_{3}\right), 39.8\left(\mathrm{CH}_{3}\right), 54.6\left(\mathrm{CH}_{3}\right), 103.5(\mathrm{CH})$, $109.7(\mathrm{CH}), 113.7(\mathrm{CH}), 115.6(\mathrm{CH}), 123.3(\mathrm{CH}), 125.9(\mathrm{CH}), 126.9(\mathrm{C})$, 127.9 (C), 131.0 (CH), 139.6 (C), 151.2 (C), 155.1 (C), 164.3 (C), 193.2 (C). HRMS $\left(\mathrm{C}_{19} \mathrm{H}_{18} \mathrm{~N}_{2} \mathrm{O}_{3} \mathrm{~S}\right)$ : calcd $345.0903\left(\mathrm{M}+\mathrm{H}^{+}\right)$, found 345.0911 . HPLC: $\mathrm{C}_{18} \mathrm{t}_{\mathrm{R}}$ : $10.57 \mathrm{~min}$.

\subsubsection{Determination of aqueous solubility}

The aqueous solubility of the compounds was determined using an approach based on the saturation shake-flask method. Approximately 
$2 \mathrm{mg}$ of each compound was suspended in $0.3 \mathrm{~mL} \mathrm{pH} 7.0$ buffer in a glass vial and shaken $72 \mathrm{~h}$ at room temperature. The resulting mixture was filtrated over a $45 \mu \mathrm{m}$ filter to discard the insoluble residues and the concentration in the supernatant was measured by UV absorbance in a Helios Alfa Spectrophotometer. Previously, for each compound, we determined the maximum absorbance wavelength and a calibration curve was obtained.

\subsection{Biology}

\subsubsection{Inhibition of tubulin polymerization}

Bovine brain tubulin was isolated as previously described [23]. The assays were carried out at $\mathrm{pH} 6.7$ with $1.5 \mathrm{mg} / \mathrm{mL}$ protein and the measured ligand concentration in $0.1 \mathrm{M}$ MES buffer, $1 \mathrm{mM}$ EGTA, $1 \mathrm{mM}$ $\mathrm{MgCl}_{2}, 1 \mathrm{mM} \beta$-ME, $1.5 \mathrm{mM}$ GTP. The samples were incubated at $20{ }^{\circ} \mathrm{C}$ for $30 \mathrm{~min}$ and subsequently cooled on ice for $10 \mathrm{~min}$. Tubulin polymerization was monitored by measuring the turbidimetry increase in the UV at $450 \mathrm{~nm}$ caused by a temperature shift from $4{ }^{\circ} \mathrm{C}$ to $37^{\circ} \mathrm{C}$. After reaching a stable plateau, temperature was switched back to $4{ }^{\circ} \mathrm{C}$ and return to the initial absorption values was ascertained, in order to confirm the reversible nature of the monitored process. The difference in amplitude between the stable plateau and the initial baseline of the curves was taken as the degree of tubulin assembly for each experiment. Comparison with control curves with identical conditions but without ligands yielded tubulin polymerization inhibition as a percentage value. Initially, all compounds were assayed at a concentration of $5 \mu \mathrm{M}$ in at least two independent measurements, and those displaying a TPI higher than $40 \%$ were selected for further studies. The tubulin polymerization inhibitory activity of the selected compounds was measured at different ligand concentrations and, as expected, the extent of inhibition by all compounds increased monotonically with the mole ratio of the total ligand to total tubulin in the solution. The obtained values were fitted to monoexponential curves and the $\mathrm{IC}_{50}$ values of tubulin polymerization inhibition were calculated from the best fitting curves.

\subsubsection{Cell culture}

HL-60 (human acute myeloid leukemia) and HT-29 (human colon carcinoma) cell lines were grown in RPMI-1640 culture medium containing $10 \%(\mathrm{v} / \mathrm{v})$ heat-inactivated fetal bovine serum (FBS), $2 \mathrm{mM}$ Lglutamine, $100 \mathrm{U} / \mathrm{mL}$ penicillin, and $100 \mu \mathrm{g} / \mathrm{mL}$ streptomycin at $37{ }^{\circ} \mathrm{C}$ in humidified $95 \%$ air and $5 \% \mathrm{CO}_{2}$. HeLa (human cervical carcinoma) cell line was grown in DMEM culture medium containing $10 \%(\mathrm{v} / \mathrm{v})$ heat-inactivated fetal bovine serum (FBS), $2 \mathrm{mM}$ L-glutamine, $100 \mathrm{U} /$ $\mathrm{mL}$ penicillin, and $100 \mu \mathrm{g} / \mathrm{mL}$ streptomycin at $37{ }^{\circ} \mathrm{C}$ in humidified $95 \%$ air and $5 \% \mathrm{CO}_{2}$. Cells were periodically tested for Mycoplasma infection and found to be negative.

\subsubsection{Cell growth inhibition assay}

The effect of the different compounds on the proliferation of human tumour cell lines (cytostatic activity) was determined as previously described [27] using the XTT (sodium 3'-[1-(phenylaminocarbonyl)3,4-tetrazolium]-bis(4-methoxy-6-nitro)-benzenesulfonic acid hydrate) cell proliferation kit (Roche Molecular Biochemicals, Mannheim, Germany) according to the manufacturer's instructions. Cells $\left(1.5 \times 10^{3}\right.$ HeLa, $3 \times 10^{3}$ HT-29 and $5 \times 10^{3}$ HL-60 in $100 \mu \mathrm{L}$ ) were incubated in culture medium containing $10 \%$ heat-inactivated FBS, in the absence and in the presence of the indicated compounds at different concentration ranges from $10^{-5}$ to $10^{-13} \mathrm{M}$, in 96-well flat-bottomed microtiter plates, and following $72 \mathrm{~h}$ of incubation at $37{ }^{\circ} \mathrm{C}$ in a humidified atmosphere of air/ $\mathrm{CO}_{2}(19 / 1)$, the XTT assay was performed. Measurements were performed in triplicate, and each experiment was repeated three times. The $\mathrm{IC}_{50}$ (50\% inhibitory concentration) value, defined as the drug concentration required to cause $50 \%$ inhibition in cellular proliferation with respect to the untreated controls, was determined for each compound. Nonlinear curve fitting of the experimental data was carried out for each compound.

\subsubsection{Cell cycle analysis}

For cell cycle analyses, untreated and drug-treated cells $\left(2-4 \times 10^{5}\right)$ were centrifuged and fixed overnight in $70 \%$ ethanol at $4{ }^{\circ} \mathrm{C}$. Then cells were washed three times with PBS, incubated for $1 \mathrm{~h}$ with $1 \mathrm{mg} / \mathrm{mL}$ RNase $\mathrm{A}$ and $20 \mu \mathrm{g} / \mathrm{mL}$ propidium iodide at room temperature, and analyzed with a Becton Dickinson fluorescence-activated cell sorter (FACSCalibur) flow cytometer (San Jose, CA) as previously described $[34,35]$. Quantification of apoptotic cells was calculated as the percentage of cells in the sub- $\mathrm{G}_{0} / \mathrm{G}_{1}$ region in cell cycle analysis $[34,35]$.

\subsubsection{Confocal microscopy}

HeLa cells were grown on $0.01 \%$ poly-L-lysine coated coverslips, and after drug treatment, the coverslips were washed three times with HPEM buffer (25 mM HEPES, $60 \mathrm{mM}$ PIPES, $10 \mathrm{mM}$ EGTA, $3 \mathrm{mM}$ $\mathrm{MgCl}_{2}, \mathrm{pH}$ 6.6), fixed with $4 \%$ formaldehyde in HPEM buffer for $20 \mathrm{~min}$, and permeabilized with $0.5 \%$ Triton X-100 as previously described [21]. Coverslips were incubated with a specific Ab-1 anti- $\alpha$ tubulin mouse monoclonal antibody (diluted 1:150 in PBS) (Calbiochem, San Diego, CA) for $1 \mathrm{~h}$, washed four times with PBS, and then incubated with CY3-conjugated sheep antimouse IgG (diluted 1:100 in PBS) (Jackson ImmunoResearch, West Grove, PA) for $1 \mathrm{~h}$ at $4{ }^{\circ} \mathrm{C}$. After four washes with PBS, a drop of SlowFade light antifading reagent (Molecular Probes, Eugene, OR), with DAPI (Sigma, St. Louis, MO) to stain cell nuclei, was added to preserve fluorescence. The samples were analyzed by confocal microscopy using a ZeissLSM 310 laser scan confocal microscope. Negative controls, lacking the primary antibody or using an irrelevant antibody, showed no staining.

\subsection{Computational studies}

\subsubsection{Chemical structure}

Calculations were performed at the molecular mechanics level (MMFF94s), semiempirical level (AM1), and B3LYP 6-31+G* DFT levels using the Spartan 08 software package. Conformational analyses with the MMFF94s forcefield were performed by systematically rotating in $18^{\circ}$ steps the bonds between the rings and the pending substituents and subjected to further unrestrained energy minimization steps at the B3LYP/6-31 + G* DFT level of theory.

\subsubsection{Docking experiments}

The coordinates of the tubulin - colchicine site ligands complexes available were retrieved from the pdb [36] and chains C - E were removed. Five additional tubulin models were built from 1SA1.pdb after energy minimization and molecular dynamics simulations at $300 \mathrm{~K}$, initially with a restrained backbone and then with an unrestrained one using AMBER14 [37] and representative structures were selected as previously described [28]. The ligands were built with Spartan 08 [38], prepared with AutodockTools and docked with AutoDock $4.2[30,39]$, by running the Lamarckian genetic algorithm (LGA) 100-300 times with a maximum of $2.5 \times 10^{6}$ energy evaluations, 150 individuals in the population, and a maximum of 27,000 generations, and PLANTS [29]. The binding poses were automatically classified by the binding pockets they occupy and the results tabulated using KNIME pipelines. The binding energies assigned by every docking program to all the poses were automatically converted to $z$-scores by dividing the energy difference of each pose to the highest pose by the difference between the highest and the lowest values for that compound. The $0-1$ valued z-scores were used for ranking the docking poses in a way independent of the program used to score the poses. The results were analyzed with Chimera [40], AutoDockTools [30,39], Marvin [41], OpenEye [42] and with JADOPPT [43]. Docking poses were selected if they were found by the two docking programs in the two first quartiles and above any alternative based on the combined $z$ scoring. 


\section{Declaration of Competing Interest}

The authors declare that they have no known competing financial interests or personal relationships that could have appeared to influence the work reported in this paper.

\section{Acknowledgements}

We thank the people at Frigoríficos Salamanca S.A. slaughter-house for providing us with the calf brains and "Servicio General de NMR" and "Servicio General de Espectrometría de Masas" of the Universidad de Salamanca for equipment. L.A. acknowledges a predoctoral fellowship from the Junta de Castilla y León. A.V.B acknowledges a predoctoral fellowship from the Spanish Ministerio de Educación, Cultura y Deporte (FPU15/02457).

\section{Funding sources}

This work was supported by the Consejería de Educación de la Junta de Castilla y León (SA030U16 and SA262P18), co-funded by the EU's European Regional Development Fund-FEDER, and the Spanish Ministry of Science, Innovation and Universities (RTI2018-099474-BI00 and SAF2017-89672-R).

\section{Appendix A. Supplementary material}

Supplementary data to this article can be found online at https:// doi.org/10.1016/j.bioorg.2020.103755.

\section{References}

[1] C. Dumontet, M.A. Jordan, Microtubule-binding agents: a dynamic field of cancer therapeutics, Nat. Rev. Drug Discovery 9 (2010) 790-803, https://doi.org/10. $1038 / \mathrm{nrd} 3253$.

[2] A. Vicente-Blazquez, M. Gonzalez, R. Alvarez, S. Del Mazo, M. Medarde, R. Pelaez, Antitubulin sulfonamides: The successful combination of an established drug class and a multifaceted target, Med. Res. Rev. (2018), https://doi.org/10.1002/med. 21541.

[3] F. Mollinedo, C. Gajate, Microtubules, microtubule-interfering agents and apoptosis, Apoptosis: Int. J. Programmed Cell Death 8 (2003) 413-450, https://doi.org/ 10.1023/A:1025513106330.

[4] M.J. Perez-Perez, E.M. Priego, O. Bueno, M.S. Martins, M.D. Canela, S. Liekens, Blocking blood flow to solid tumors by destabilizing tubulin: an approach to targeting tumor growth, J. Med. Chem. 59 (2016) 8685-8711, https://doi.org/10. 1021/acs.jmedchem.6b00463.

[5] S.J. Lunt, S. Akerman, S.A. Hill, M. Fisher, V.J. Wright, C.C. Reyes-Aldasoro, G.M. Tozer, C. Kanthou, Vascular effects dominate solid tumor response to treatment with combretastatin A-4-phosphate, Int. J. Cancer 129 (2011) 1979-1989, https://doi.org/10.1002/ijc.25848.

[6] D.W. Siemann, The unique characteristics of tumor vasculature and preclinical evidence for its selective disruption by Tumor-Vascular Disrupting Agents, Cancer Treat. Rev. 37 (2011) 63-74, https://doi.org/10.1016/j.ctrv.2010.05.001.

[7] W. Liang, Y. Ni, F. Chen, Tumor resistance to vascular disrupting agents: mechanisms, imaging, and solutions, Oncotarget 7 (2016) 15444-15459, https://doi.org/ 10.18632/oncotarget.6999.

[8] G.M. Tozer, C. Kanthou, G. Lewis, V.E. Prise, B. Vojnovic, S.A. Hill, Tumour vascular disrupting agents: combating treatment resistance, Br. J. Radiol. 81 Spec No 1 (2008) S12-20. doi: 10.1259/bjr/36205483.

[9] G.C. Tron, T. Pirali, G. Sorba, F. Pagliai, S. Busacca, A.A. Genazzani, Medicinal chemistry of combretastatin A4: present and future directions, J. Med. Chem. 49 (2006) 3033-3044, https://doi.org/10.1021/jm0512903.

[10] S. Aprile, E. Del Grosso, G.C. Tron, G. Grosa, In vitro metabolism study of combretastatin A-4 in rat and human liver microsomes, Drug Metabolism Disposition: Biol. Fate Chem. 35 (2007) 2252-2261, https://doi.org/10.1124/dmd.107.016998.

[11] G.R. Pettit, B. Toki, D.L. Herald, P. Verdier-Pinard, M.R. Boyd, E. Hamel, R.K. Pettit, Antineoplastic agents. 379. Synthesis of phenstatin phosphate, J. Med. Chem. 41 (1998) 1688-1695, https://doi.org/10.1021/jm970644q.

[12] A.M. Malebari, L.M. Greene, S.M. Nathwani, D. Fayne, N.M. O'Boyle, S. Wang, B. Twamley, D.M. Zisterer, M.J. Meegan, beta-Lactam analogues of combretastatin A-4 prevent metabolic inactivation by glucuronidation in chemoresistant HT-29 colon cancer cells, Eur. J. Med. Chem. 130 (2017) 261-285, https://doi.org/10. 1016/j.ejmech.2017.02.049.

[13] R. Kaur, G. Kaur, R.K. Gill, R. Soni, J. Bariwal, Recent developments in tubulin polymerization inhibitors: An overview, Eur. J. Med. Chem. 87 (2014) 89-124, https://doi.org/10.1016/j.ejmech.2014.09.051.

[14] Y. Lu, J. Chen, M. Xiao, W. Li, D.D. Miller, An overview of tubulin inhibitors that interact with the colchicine binding site, Pharm. Res. 29 (2012) 2943-2971, https://doi.org/10.1007/s11095-012-0828-z.

[15] R. Alvarez, C. Alvarez, F. Mollinedo, B.G. Sierra, M. Medarde, R. Pelaez, Isocombretastatins A: 1,1-diarylethenes as potent inhibitors of tubulin polymerization and cytotoxic compounds, Bioorg. Med. Chem. 17 (2009) 6422-6431, https://doi.org/10.1016/j.bmc.2009.07.012.

[16] N. Sirisoma, A. Pervin, H. Zhang, S. Jiang, J.A. Willardsen, M.B. Anderson, G. Mather, C.M. Pleiman, S. Kasibhatla, B. Tseng, J. Drewe, S.X. Cai, Discovery of N (4-methoxyphenyl)-N,2-dimethylquinazolin-4-amine, a potent apoptosis inducer and efficacious anticancer agent with high blood brain barrier penetration, J. Med. Chem. 52 (2009) 2341-2351, https://doi.org/10.1021/jm801315b.

[17] T.M. Beale, D.M. Allwood, A. Bender, P.J. Bond, J.D. Brenton, D.S. Charnock-Jones, S.V. Ley, R.M. Myers, J.W. Shearman, J. Temple, J. Unger, C.A. Watts, J. Xian, Aring dihalogenation increases the cellular activity of combretastatin-templated tetrazoles, ACS Med. Chem. Lett. 3 (2012) 177-181, https://doi.org/10.1021/ $\mathrm{ml} 200149 \mathrm{~g}$.

[18] R. Alvarez, L. Aramburu, P. Puebla, E. Caballero, M. Gonzalez, A. Vicente, M. Medarde, R. Pelaez, Pyridine based antitumour compounds acting at the colchicine site, Curr. Med. Chem. 23 (2016) 1100-1130, https://doi.org/10.2174/ 092986732311160420104823.

[19] F. Xu, W. Li, W. Shuai, L. Yang, Y. Bi, C. Ma, H. Yao, S. Xu, Z. Zhu, J. Xu, Design, synthesis and biological evaluation of pyridine-chalcone derivatives as novel microtubule-destabilizing agents, Eur. J. Med. Chem. 173 (2019) 1-14, https://doi. org/10.1016/j.ejmech.2019.04.008.

[20] C. Alvarez, R. Alvarez, P. Corchete, C. Perez-Melero, R. Pelaez, M. Medarde, Naphthylphenstatins as tubulin ligands: synthesis and biological evaluation, Bioorg. Med. Chem. 16 (2008) 8999-9008, https://doi.org/10.1016/j.bmc.2008.08.040.

[21] A.B. Maya, C. Perez-Melero, C. Mateo, D. Alonso, J.L. Fernandez, C. Gajate, F. Mollinedo, R. Pelaez, E. Caballero, M. Medarde, Further naphthylcombretastatins. An investigation on the role of the naphthalene moiety, J. Med. Chem. 48 (2005) 556-568, https://doi.org/10.1021/jm0310737.

[22] R. Alvarez, C. Gajate, P. Puebla, F. Mollinedo, M. Medarde, R. Pelaez, Substitution at the indole 3 position yields highly potent indolecombretastatins against human tumor cells, Eur. J. Med. Chem. 158 (2018) 167-183, https://doi.org/10.1016/j. ejmech.2018.08.078.

[23] R. Alvarez, P. Puebla, J.F. Diaz, A.C. Bento, R. Garcia-Navas, J. de la Iglesia-Vicente, F. Mollinedo, J.M. Andreu, M. Medarde, R. Pelaez, Endowing indole-based tubulin inhibitors with an anchor for derivatization: highly potent 3-substituted indolephenstatins and indoleisocombretastatins, J. Med. Chem. 56 (2013) 2813-2827, https://doi.org/10.1021/jm3015603.

[24] C. Jimenez, Y. Ellahioui, R. Alvarez, L. Aramburu, A. Riesco, M. Gonzalez, A. Vicente, A. Dahdouh, A. Ibn Mansour, C. Jimenez, D. Martin, R.G. Sarmiento, M. Medarde, E. Caballero, R. Pelaez, Exploring the size adaptability of the B ring binding zone of the colchicine site of tubulin with para-nitrogen substituted isocombretastatins, Eur. J. Med. Chem. 100 (2015) 210-222, https://doi.org/10. 1016/j.ejmech.2015.05.047.

[25] K.E. Henegar, S.W. Ashford, T.A. Baughman, J.C. Sih, R.-L. Gu, Practical Asymmetric Synthesis of (S)-4-Ethyl-7,8-dihydro-4-hydroxy-1H-pyrano[3,4-f]indolizine- 3,6,10(4H)-trione, a Key Intermediate for the Synthesis of Irinotecan and Other Camptothecin Analogs, J. Organic Chem. 62 (1997) 6588-6597, https://doi. org/10.1021/jo970173f.

[26] J. Chen, Z. Wang, C.M. Li, Y. Lu, P.K. Vaddady, B. Meibohm, J.T. Dalton, D.D. Miller, W. Li, Discovery of novel 2-aryl-4-benzoyl-imidazoles targeting the colchicines binding site in tubulin as potential anticancer agents, J. Med. Chem. 53 (2010) 7414-7427, https://doi.org/10.1021/jm100884b.

[27] M.H. David-Cordonnier, C. Gajate, O. Olmea, W. Laine, J. de la Iglesia-Vicente, C. Perez, C. Cuevas, G. Otero, I. Manzanares, C. Bailly, F. Mollinedo, DNA and nonDNA targets in the mechanism of action of the antitumor drug trabectedin, Chem. Biol. 12 (2005) 1201-1210, https://doi.org/10.1016/j.chembiol.2005.08.009.

[28] R. Alvarez, M. Medarde, R. Pelaez, New ligands of the tubulin colchicine site based on X-ray structures, Curr. Top. Med. Chem. 14 (2014) 2231-2252, https://doi.org/ 10.2174/1568026614666141130092637.

[29] O. Korb, T. Stutzle, T.E. Exner, Empirical scoring functions for advanced proteinligand docking with PLANTS, J. Chem. Inf. Model. 49 (2009) 84-96, https://doi. org/10.1021/ci800298z.

[30] S. Forli, R. Huey, M.E. Pique, M.F. Sanner, D.S. Goodsell, A.J. Olson, Computational protein-ligand docking and virtual drug screening with the AutoDock suite, Nat. Protoc. 11 (2016) 905-919, https://doi.org/10.1038/nprot.2016.051.

[31] A. Massarotti, A. Coluccia, R. Silvestri, G. Sorba, A. Brancale, The tubulin colchicine domain: a molecular modeling perspective, ChemMedChem 7 (2012) 33-42, https://doi.org/10.1002/cmdc.201100361.

[32] R. Gaspari, A.E. Prota, K. Bargsten, A. Cavalli, M.O. Steinmetz, Structural Basis of cis- and trans-Combretastatin Binding to Tubulin, Chem 2 (2017) 102-113, https:// doi.org/10.1016/j.chempr.2016.12.005.

[33] S. Banerjee, K.E. Arnst, Y. Wang, G. Kumar, S. Deng, L. Yang, G.B. Li, J. Yang, S.W. White, W. Li, D.D. Miller, Heterocyclic-fused pyrimidines as novel tubulin polymerization inhibitors targeting the colchicine binding site: structural basis and antitumor efficacy, J. Med. Chem. 61 (2018) 1704-1718, https://doi.org/10.1021/ acs.jmedchem.7b01858.

[34] C. Gajate, A.M. Santos-Beneit, A. Macho, M. Lazaro, A. Hernandez-De Rojas, M. Modolell, E. Munoz, F. Mollinedo, Involvement of mitochondria and caspase-3 in ET-18-OCH(3)-induced apoptosis of human leukemic cells, Int. J. Cancer 86 (2000) 208-218.

[35] C. Gajate, I. Barasoain, J.M. Andreu, F. Mollinedo, Induction of apoptosis in leukemic cells by the reversible microtubule-disrupting agent 2-methoxy-5-(2',3',4' trimethoxyphenyl)-2,4,6-cycloheptatrien-1 -one: protection by $\mathrm{Bcl}-2$ and $\mathrm{Bcl}-\mathrm{X}(\mathrm{L})$ 
and cell cycle arrest, Cancer Res. 60 (2000) 2651-2659.

[36] S. Aprile, E. Del Grosso, G. Grosa, Identification of the human UDP-glucuronosyltransferases involved in the glucuronidation of combretastatin A-4, Drug Metabolism Disposition: Biol. Fate Chem. 38 (2010) 1141-1146, https://doi.org/ 10.1124/dmd.109.031435.

[37] D.A. Case, T.E. Cheatham 3rd, T. Darden, H. Gohlke, R. Luo, K.M. Merz Jr., A. Onufriev, C. Simmerling, B. Wang, R.J. Woods, The Amber biomolecular simulation programs, J. Comput. Chem. 26 (2005) 1668-1688, https://doi.org/10. 1002/jcc. 20290.

[38] I. WAVEFUNCTION, Spartan08, in, 2008.

[39] G.M. Morris, R. Huey, W. Lindstrom, M.F. Sanner, R.K. Belew, D.S. Goodsell, A.J. Olson, AutoDock4 and AutoDockTools4: Automated docking with selective receptor flexibility, J. Comput. Chem. 30 (2009) 2785-2791, https://doi.org/10. $1002 / j c c .21256$.

[40] E.F. Pettersen, T.D. Goddard, C.C. Huang, G.S. Couch, D.M. Greenblatt, E.C. Meng, T.E. Ferrin, UCSF Chimera-a visualization system for exploratory research and analysis, J. Comput. Chem. 25 (2004) 1605-1612, https://doi.org/10.1002/jcc. 20084.

[41] Marvin 17.8 in, ChemAxon (http://www.chemaxon.com), 2017.

[42] OpenEye Scientific Software, Inc, Santa Fe in OpenEye (https://www.eyesopen. com), 2019.

[43] C. Garcia-Perez, R. Pelaez, R. Theron, J. Luis Lopez-Perez, JADOPPT: java based AutoDock preparing and processing tool, Bioinformatics 33 (2017) 583-585, https://doi.org/10.1093/bioinformatics/btw677. 